Portland State University

PDXScholar

10-20-1987

\title{
Classifying Oregon Lake-Watershed Ecosystems for Regional Water Resources Assessment
}

\author{
Randall Alan Jones \\ Portland State University
}

Follow this and additional works at: https://pdxscholar.library.pdx.edu/open_access_etds

Part of the Geography Commons, Hydrology Commons, and the Terrestrial and Aquatic Ecology Commons

Let us know how access to this document benefits you.

\section{Recommended Citation}

Jones, Randall Alan, "Classifying Oregon Lake-Watershed Ecosystems for Regional Water Resources Assessment" (1987). Dissertations and Theses. Paper 3712.

https://doi.org/10.15760/etd.5596

This Thesis is brought to you for free and open access. It has been accepted for inclusion in Dissertations and Theses by an authorized administrator of PDXScholar. Please contact us if we can make this document more accessible: pdxscholar@pdx.edu. 
AN ABSTRACT OF THE THESIS OF Randa11 Alan Jones for the Master of Science in Geography presented October 20, 1987.

Title: Classifying Oregon Lake-Watershed Ecosystems For Regional Water Resources Assessment.

APPROVED BY MEMBERS OF THE THESIS COMMITTEE:

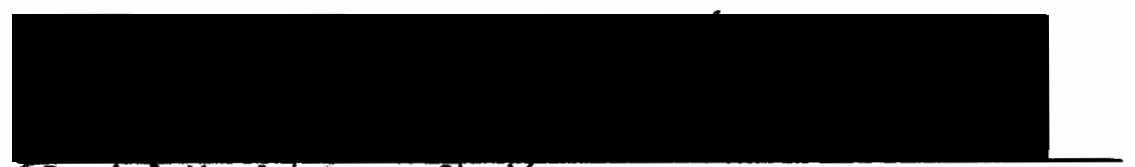

Daniel M. Johnson, Chajrman

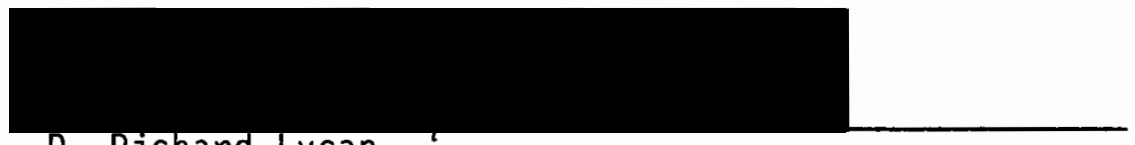

D. Richard Lycan

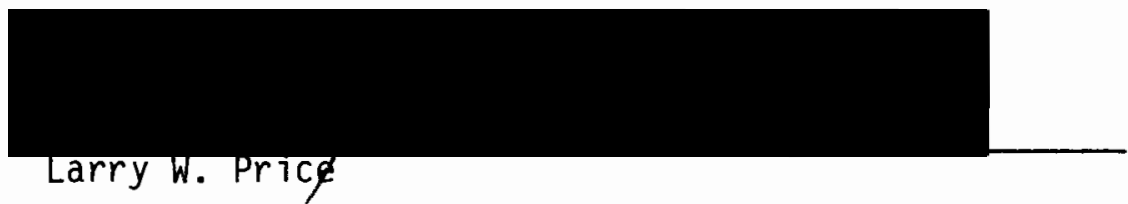

Natural lake-watershed ecosystems in Oregon compose a diverse and valuable assemblage of land and water resources. With an increasing demand on lakes for recreation, water supplies, and asthetic values and an increase in available data on Oregon lake systems, there is a need for applicable and timely scientific water management information about lake conditions statewide. This thes is is an attempt to summarize some of the data collected on natural Oregon lake-watershed ecosystems.

The purpose of the thesis is to identify the most typical natural systems out of an initial data base of twenty-four variables, measured over ninety-eight lake-watershed ecosystems. The selected variables are 
reduced to five common factors using principal components factor analysis. K-means cluster analysis is used to create similar groups of lake systems. These groups are compared to ecoregions in Oregon and a typical, representative lake ecosystem is identified for each group. Results show that several lake systems of the state are unique. 
CLASSIFYING OREGON LAKE-WATERSHED ECOSYSTEMS FOR REGIONAL WATER RESOURCES ASSESSMENT

by

RANDALL ALAN JONES

A thes is submitted in partial fulfillment of the requirements for the degree of

MASTER OF SCIENCE

GEOGRAPHY

Portland State University 
TO THE OFFICE OF GRADUATE STUDIES AND RESEARCH:

The members of the committee approve the thesis of Randall Alan Jones presented October 20, 1987.
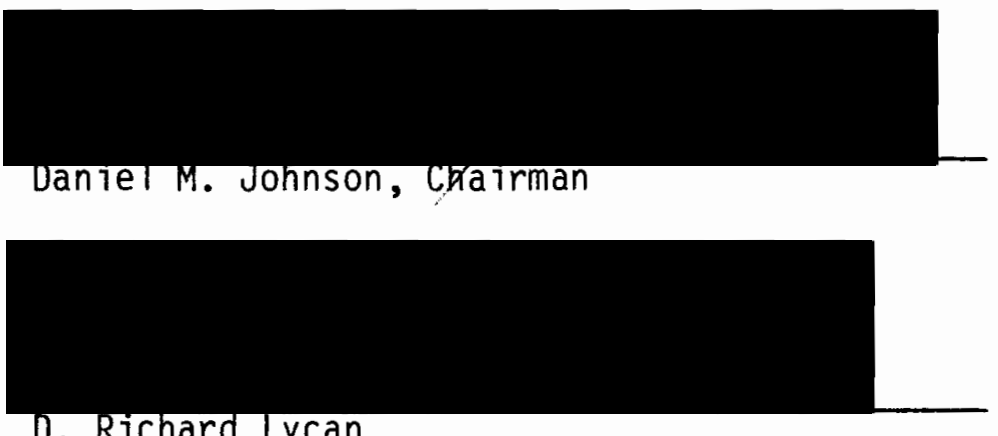

0. Richard Lycan

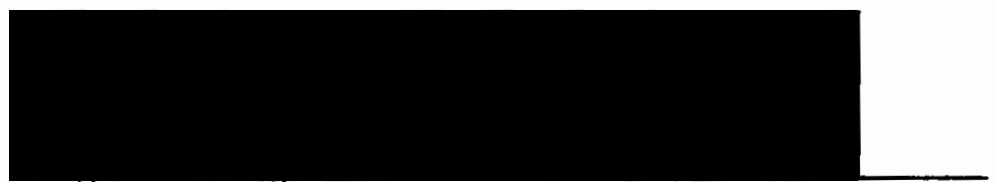

Larry W. Prjce

APPROVED :
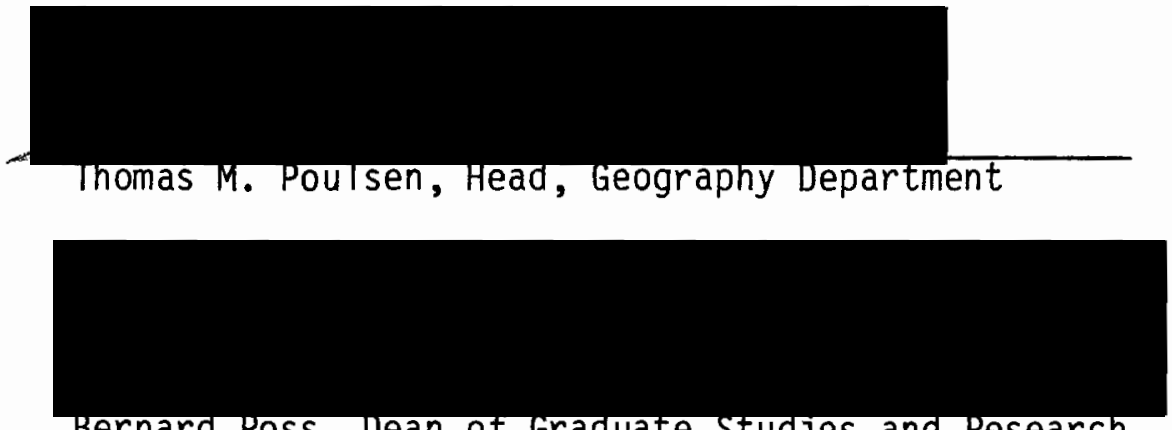

Bernard Ross, Uean of Graduate Studies and Research 


\section{ACKNOWLEDGEMENTS}

The production of this thesis was a process. The process was not progressive from stage to stage, but an evolution of ideas and perspectives on a very important and complex topical area. My advisor, Daniel Johnson, was a patient guide from start to finish; in him I found a ready sounding-board and friend. Data generation and collation was a major effort and I am indebted to Holly Yocum for her many hours of concentration and capable assistance in that effort. Daniel Kjerne helped with the initial statistical phases of cluster analysis, and Richard Lycan spent many hours familiarizing me with the statistical computer programs and data interpretation. Larry Price, Gil Latz, James Sweet, Andrew Schaedel, and Andrew Kinney all were open to my queries and freely offered their time and advice. Carolyn Perry, as always, provided much-needed administrative and moral support.

I am convinced that a student can learn as much from his or her peers as from texts, articles, or instructors. To my fellow students, past and present, I am grateful. In a very real sense, my family and friends had influence on and, in turn, were influenced by the thes is process. I am very proud to say that each owns a part of this document.

Finally, the primary thesis editor and graphic artist, and my main confidante is the person I most love -- my wife Ellen Bartsch Jones. In so many ways Ellen, your understanding, compassion, and your hard work are integrated in the words and numbers that are this thesis. 
TABLE OF CONTENTS

PAGE

ACKNOWLEDGEMENTS ...............................

LIST OF TABLES................................ vi

LIST OF FIGURES ............................... vii

CHAPTER

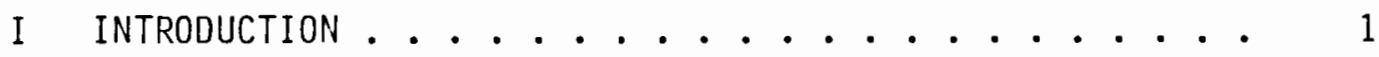

The Need for Lake and Watershed Classification . . 2

Geography and Limnology ........... 4

The Geographical Study of Lake Systems ..... . 5

II WATERSHEDS AND LAKES: AN ECOSYSTEM APPROACH . . . . 7

Watersheds as the Basic Ecosystem . . . . . . 7

The Lake-Watershed Ecosystem as a Biophysical

Continuum ................. 8

Lake Eutrophication .......... . 10

III ECOLOGICAL CLASSIFICATION ............. 14

Review of Land-type Classification ....... 16

Review of Aquatic Classification ....... 18

Lake Trophic State Classification

Lake-Watershed Classification

Ecoregional Classification ........ 24 
CHAPTER

PAGE

IV OREGON LAKE WATERSHED ECOSYSTEMS . . . . . . . . . . . 30

Variable Sources, Definitions, and Explanations . . 30

Descriptions of the Lake-Watershed Ecosystems . . . 46

V DATA ANALYSIS . . . . . . . . . . . . . . 73

Interpretation of Factor Analys is Results . . . . 76

Cluster Analysis . . . . . . . . . . . . 81

VI DISCUSSION AND CONCLUSIONS . . . . . . . . . . . . 84

Conclusions . . . . . . . . . . . . . 87

VII SUGGESTED RESEARCH . . . . . . . . . . . . . . . 89

REFERENCES • . . . . . . . . . . . . . . . . . . . . 92

APPENDIX A . . . . . . . . . . . . . . . . . . . . 103

APPENDIX B . . . . . . . . . . . . . . . . . . . . . 106

APPENDIX C . . . . . . . . . . . . . . . . . . . . 110

APPENDIX D. . . . . . . . . . . . . . . . . . . . . . 113 


\section{LIST OF TABLES}

TABLE

PAGE

I Types of Trophic State Indices Developed For Lakes

by Various Authors . . . . . . . . . . . .

II Quantitative Trophic State Limits Proposed By Various

Authors Based on Chlorophyl1-a, Total-phosphorus, and Water Transparency . . . . . . . . . 20

II Characteristics of Ecoregions in the Pacific Northwest. . 28

IV Variable Descriptions . . . . . . . . . . 32

V Variable Explanations . . . . . . . . . . . . 33

VI Rotated Factor Loading Matrix Sorted By Factor . . . . . . 75

VII Factor Score Matrix Sorted By Factor . . . . . . . . 77

VII K-Means Cluster Analysis Results . . . . . . . . . 82

IX Secondary K-Means Cluster Analys is Results . . . . . 83

X Typical Lake-Watershed Ecosystems and Associated Factors and Variables . . . . . . . . . . . . . . 


\section{LIST OF FIGURES}

FIGURE

PAGE

1. The Trophic State Concept ............. 11

2. Oregon Ecoregions ............. . . 27

3. Ecoregions of Oregon .............. 29

4. Oregon Lake-Watershed Ecosystems ............ 31

5. U.S. Geological Survey Hydrographic Regions ....... 39

6. Mean Annual Flood Calculation Graph for Watersheds Outside

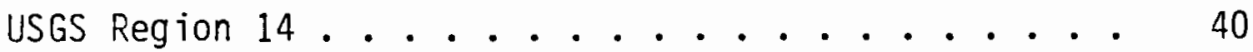

7. Dendritic Mercer Lake ............. . 49

8. Woahink Lake Near Florence ............ 52

9. Waldo Lake and Impounding Moraines . . . . . . . . 58

10. Marion Lake and Three Fingered Jack ......... 58

11. Eutrophic Delintment Lake ............ 69

12. 01 igotrophic Mirror Lake in the Wallowa Mountains . . . 70

13. Glacial Moraines Impound Wallowa Lake ......... 72

14. Wallowa Lake's Watershed is Steep and Dissected . . . . 72

15. The Factor Analys is Procedure ........... 74

16. Actual USGS Runoff Data vs. Estimated Runoff Values . . . 111 


\section{CHAPTER I}

INTRODUCTION

The diversity and distribution of lakes in Oregon reflect the varying nature of environmental conditions in the state. The environmental conditions under which they were formed, as well as the conditions that exist at the present, have resulted in a remarkable range of lake types and sizes, lake water quality, and lake uses. With several thousand lakes in the state and an increase in the human use of those waters there is a need for applicable and timely scientific and water management information about water quality and quantity statewide. This research is an attempt to summarize some of the data that has been collected pertaining to Oregon lakes.

The purpose of this research is to identify the most typical natural lake-watershed ecosystems in Oregon. Lake-watershed ecosystems are first classified by both watershed and in-lake characteristics using the multivariate statistical techniques of factor analys is and cluster analysis to establish groups of similar systems. These groups are compared to Oregon eccregions and a typical, representative lake-watershed ecosystem type is then identified for each group. The focus is on the watershed -- the terrestrial portion of a lake ecosystem -- and is based on the idea that the biophysical conditions within lakes are determined to a large degree by the characteristics of and activities within a lake's watershed. 
Establishing a baseline type of lake-watershed ecosystem, in a regional context, will make the efforts of water managers and decision-makers more effective in selecting sites for water quality monitoring programs and in assessing impacts on water quality across similarly defined lake-watershed ecosystems. Individuals and agencies responsible for the evaluation of environmental quality in Oregon can benefit also from a regional classification of lake-watershed ecosystems, as there are over six-thousand bodies of standing water in the state. The extreme ranges of climate, geology, vegetation, and lake types in the state provide a unique opportunity to develop a method to typify lake systems. No such method has yet been established for Oregon lakes.

THE NEED FOR LAKE AND WATERSHED CLASSIFICATION

The need for lake classification has long been recognized. Researchers in biology, limnology, watershed and water quality management, and geography have stressed the need for macroscale assessments of the world's lakes (Horne, et al. 1975; Wetzel 1975; Sheldon 1976; and Taub 1984). Lake classifications communicate the general nature of a lake or group of lakes. Regional water planning demands an interdisciplinary or synthesizing approach to the study of watersheds and lakes by land and water specialists because, in large part, the goal of both scientific water research and comprehensive water management efforts is to understand the complex operation of freshwater ecosystems and the application of such knowledge to solving practical problems of resource utilization and conservation. 
The trophic state approach to lake classification has been developed to characterize and compare the water quality of lakes. The trophic state concept and its associated indices has provided a conceptual strategy for classifying lakes by attempting to define the limits of oligotrophy, mesotrophy, and eutrophy. However, the various techniques offered to define a lake's trophic state have traditionally been limited to "within-lake" measures and observations on the biological, chemical, and physical properties of the lake itself. Though they have proven usefur, with some limitations, these in-lake approaches to water quality assessment have seemingly ignored the idea that any given lake derives much of its character and quality from its respective watershed (Lotspeich 1980; Chorley 1969; Gregory and Walling 1973). Therefore, in classifying a lake for the purpose of assessing its water quality, watershed components must also be incorporated into the classification.

Focusing research efforts on lake watersheds enables scientists to identify and evaluate the processes and activities that contribute to the quality of lake water downstream. A major obstacle inherent to such an approach is the selection of the variables that adequately reflect the total lake biogeochemical system; relationships among some system components are often either not well understood or cannot be accurately and sufficiently quantified to include in useable classifications and the methods by which the components are combined are sometimes questionable. A method to estimate lake system dynamics based on observed processes and activities in the watershed is requisite to water quality planning, especially in a regional context where each lake 
cannot be sampled and monitored on an ongoing basis.

\section{GEOGRAPHY AND LIMNOLOGY}

Contemporary lake studies have been dominated by the discipline of limnology. Although geographers are frequently concerned with the geomorphic and cartographic aspects of limnology they have not, as a general rule, been concerned with the myriad of biological, chemical, or physical processes which constitute the core of 1 imnological research. The subject matter of limnology is centered on the study of the structure and function of fresh water, with particular regard for the understanding of metabolic responses of aquatic ecosystems (Wetzel 1975, p. 4).

Geographers analyze patterns of phenomena according to the spatial attributes of location, extent, and density of features. The result of geographical analysis over time is that the phenomena being studied assume a fourth dimension -- succession. The ability to utilize and interpret diverse types of data, and contrast and compare water ecosystems with respect to their spatial and temporal distribution is one of the most significant contributions geographers can make to limnology. There are topics of common interest to the geographer and limnologist where either discipline can be a valuable adjunct to the other. Regional or comparative limnology is one of these common topics where the specialties of each field overlap: the in-lake approach of the limnologist and the spatial, synthesizing approach of the geographer. 
THE GEOGRAPHICAL STUDY OF LAKE SYSTEMS

Geographical study of entire lake-watershed ecosystems is warranted for two main reasons. First, a lake with its watershed is an excellent example of an ecosystem, because it has interacting and interdependent physical, chemical, and biological components. Lake-watershed ecosystems are essentialiy open systems as inputs of energy and matter flow through them. Furthermore, since the watershed receives the bulk of external inputs of matter and energy, the watershed controls the nature of the lake because constituents of the land are eventually contributed to lake basins. The lake itself is the local base level for its respective watershed and acts as a "sink" for sediments, nutrients, and runoff. Secondly, lake-watershed ecosystems are of significant value for human use. Regardless of their nature and location, all lakes are exposed to some degree of human influence and, in turn, all lakes represent resources of differing quality and importance to their various users. Municipal and agricultural water supplies, power generation, sport fishing, scenic and recreational qualities, unique biological or geological features, or combinations of these are attributes relating the importance of lakes themselves to people. In turn, the mosaic of human activities on the landscape has influenced relief, drainage, soil and vegetational characteristics of watersheds and also the rate and sometimes the manner in which water, sediments, and nutrients are removed from watersheds and delivered to lakes. This complex of 
anthropogenic activities and resulting impacts make management of lake systems even more difficult in addition to inherent natural variations. 
CHAPTER II

WATERSHEDS AND LAKES: AN ECOSYSTEM APPROACH

The term "watershed" refers to the catchment area of a particular lake or stream, the perimeter of which is marked topographically by a narrow area of ground that divides two adjacent areas toward which water and sediments are transported into separate streams or lakes (Watt 1982, p. 25; Whittow 1984, pp. 154, 576). A watershed is composed of uplands -- ridges, valley walls, and stream channels -- and the riparian areas of streams and lakes. The term is commonily used by scientists, planners, and managers from many disciplines to discuss the relationships between the conditions of catchment areas and the quality and quantity of surface waters because processes operating in the watershed can directly and indirectly influence processes in a stream orin a rake.

\section{WATERSHEDS AS THE BASIC ECOSYSTEM}

Lotspeich (1980) describes the watershed as the basic ecosystem, the common denominator to describe interactions of terrestrial and aquatic systems. Lotspeich envisions the watershed as being composed of a hierarchy of controlling factors with climate and geology as the master forces, soil and vegetation as reacting elements on the next lower level, and at the base, the stream or lake which responds to all factors at higher levels. Because watersheds are defined as spatial 
units they solve the frequentry noted difficulty in the study of ecosystems -- the lack of discrete boundaries within which to structure research.

Chorley (1969) advocates the watershed as the "fundamental geomorphic unit" because the processes (e.g. erosion and sedimentation) and forms (e.g. streams lakes) on the land must be analyzed and measured within a clearly defined and unambiguous topographic unit such as a catchment area. Likens, et al. (1977) suggest the use of watersheds as ecosystems in which to study nutrient cycling, hydrological performances, geological weathering, and other natural processes. Warren (1979) recognizes the watershed as an object of "exceptional scientific and management interest" because of both the historical influence watersheds have on human cultural activity and because their definable boundaries give hydrologic systems an identifiable physical structure.

Moss (1980) offers the watershed as the basic unit of study because "a lake cannot be understood in isolation" (p. 1). Water is contributed to a lake from the watershed via tributary streams; the same water that derives much of its chemical composition from the geology, geography, and cultural development of the watershed.

THE LAKE-WATERSHED ECOSYSTEM AS A BIOPHYSICAL CONTINUUM

Lakes are widely recognized as functional, integral components of the land-water environmental system. Some of the earliest lake investigators, however, viewed lakes as "microcosms" present in, but isolated from, the rest of the landscape (Forbes 1887). Many of these 
earlier studies were of fundamental importance to the growth and development of contemporary studies in limnological research and knowledge -- a field unrivaled by any other area of ecology in its techniques and theory (Wetzel 1975, p. 134). It is now commonly accepted that lake-watershed ecosystems consist not only of the lake itself but of the entire drainage area (Hutchinson 1969, p. 271; Gregory and Walling 1973, p. 4; Wetzel 1975, p. 5; Goldman and Horne 1983, p. 19).

The dynamic equilibrium theory of fluvial geomorphology states that from headwaters to baselevel, the physical variables within a drainage system present a continuum of physical conditions along a stream or within a network of streams in which an approximate balance between energy inputs (i.e. precipitation, sediments, nutrients, and energy utilization) and energy output (i.e. runoff) is maintained (Leopold, et al. 1964; Vannote, et al. 1980). The concept implies both an adjustability of a system over time to changes in independent variables such as water and sediment loading as well as a stability in form. Mackin (1948) defined a "graded" system as a "system in equilibrium; its diagnostic characteristic is that any change in any of the controlling factors will cause a displacement of the equilibrium in a direction that will tend to absorb the effect of the change" (p. 471). Controlling factors here principally refer to the physical and chemical variables of climate and geology. Changes with in lake-watershed ecosystems causing displacement of equilibrium in input or transport mechanisms can be natural or human-caused. Ultimately, lakes as local baselevels are often the physical entities in which such displacement is reflected. 
A lake with its watershed is an open system that requires a continuing energy supply and is in effect maintained by a constant supply and removal of energy. Therefore, the watershed can be visualized as receiving energy or input from the climate over its entire area, and losing energy or output through the water and sediment contributed to a lake basin. The lake itself loses energy largely through its outlet (surface flow), groundwater seepage, and/or evaporative processes. The advantages of the open system approach stem from the idea that it places emphasis upon adjustments between input and output, and upon the relationships of process and form which constitute the entire lake-watershed ecosystem.

\section{LAKE EUTROPHICATION}

Eutrophication is the term used in the scientific community to describe the complex sequence of changes in aquatic ecosystems caused by an increased growth rate of the biota of lakes, stimulated by an increased availability and uptake of essential plant nutrients to water such as phosphorus, nitrogen, iron, and carbon. Eutrophication over time, is a collective process of "aging" which may take hundreds of years, and may be "accelerated" by human activities producing responses on time scales of decades or even a few years (Vallentyne 1974, p. 15). Accelerated or "cultural" eutrophication is a well-documented human impact upon aquatic ecosystems where excessive nutrient inputs commonly exceed the capacity of the system to be balanced.

Some lakes will be more vulnerable to environmental and/or system changes than others, but the factors producing the differences have not 
been well understood until recent years. Deevey (1984) suggests that "a general theory of a lake's [evolutionary] trajectory over time will begin with material flow through [the] ecosystem, and that the appropriate 'compartments' of a lake system used to evaluate such changes must be: 1) the lake; 2) the surrounding terrestrial ecosystems; and 3) the human society within the watershed" (p. 205).

The bulk of nutrients entering a lake are derived from its watershed via runoff and sediments. The immediate lake response is an increase in photosynthesis, increased productivity at all levels of the food chain, from phytoplankton to macrophytes, and up to and including fish (Hutchinson 1969; Vallentyne 1974, p. 10). Lake conditions represent a balance between system responses to these changes, and it is this average lake condition that constitutes the trophic state categories of oligotrophy and eutrophy, with mesotrophic lakes occupying an intermediate position between the two extremes (Figure 1).

\section{trophlo 8 tate: \\ OLIGOTROPHY MESOTROPHY \\ EUTROPHY}

Figure 1. The trophic state concept.

01 igotrophic lakes can be generally characterized as deep lakes with average depths of greater than fifteen meters (Vallentyne 1974, p. 10) that have steep shorelines, low densities of plant life in surface waters, low drainage ratios, and short hydrologic retention times. They are highly transparent with secchi disk values (depths at which a standard 12-inch black and white disk is visible) of greater than five 
meters. 01igotrophic lakes are often biologically limited by phosphorus (Wetzel 1975, p. 286), have low overall nutrient contents in relation to lake volume, high contents of dissolved oxygen, and, in general, display highly diverse assemblages of cool-water species.

Eutrophic lakes lie at the other end of the spectrum. These are the highly productive lakes -- lakes which produce large amounts of biomass per unit area and volume. Naturally eutrophic lakes are usually quite shallow and have mean depths of less than ten meters, with good supplies of all essential plant nutrients derived from nutrient-rich inflows from the watershed. Because the depth-to-volume ratios are less than oligotrophic lakes, internal recycling of nutrients from the sediments to the water is an active process in eutrophic systems (Strom 1930; and Goldman and Horne 1983, p. 349). There also tends to be a general simplification of biotic assemblages, basicalily because the numbers of species adapted to the narrower ranges of conditions in eutrophic environments decreases (Wetzel 1975, pp. 4, 646). Water color is commonly green-blue to green and secchi disk values are usually less than three meters because of the light scattering and absorbing effects of organic and inorganic suspended particulates.

The terms ol igotrophy, mesotrophy, and eutrophy are relative terms only, as lakes are undergoing continuous physical, chemical, and biological changes and adjustments in response to natural and cultural influences. Lakes are valuable for recreation, water supplies, and for aesthetic value. Increased development adjacent to lakes, and in watersheds containing lakes, has led to extensive research in watershed planning, water quality evaluation and monitoring, water and soil 
conservation, and sewage system design and planning. Ironically, in spite of the need and demand for high quality water, most development within lake-watershed ecosystems facilitates a general deterioration of water quality to some degree, and therefore a decline in scenic and recreational values.

Human resjdents within a watershed need not be located immediately adjacent to a lake to influence a lake's development and condition in fundamental ways. Watershed activities resulting in effluents of sewage, agricultural and storm-drain runoff, and sediment production from road building, construction, and logging are some of the human-induced non-point source influences in lake-watershed ecosystems. The solution to better understanding of lake-watershed ecosystem conditions and responses to natural change and human activity in a regional context begins with utilizing up-to-date, comprehensive, and accurate data and information in land and water planning and management strategies. 
CHAPTER III

\section{ECOLOGICAL CLASSIFICATION}

Classification is the systematic arrangement of phenomena into groups or categories, expressive of their natural relationships, according to a definite plan or sequence, and according to the perceived characteristics of those items (Sokal 1974; and Johnston 1976). Classification is a defense mechanism triggered by the human need to order the world and to understand how the components of socio-physical environments relate to one another; telephone directories, taxonomic keys, and lake typologies are some of the symptoms. Classification is a common attribute to all sciences and to many social sciences as weil. Problems of classification become particularly relevant to geography because of the discipline's interest in spatial patterns. Many of the systems that often interest geographers are enormously complex and inevitably require some degree of abstraction or simplification.

Regionalization is the procedure for identifying large-scale spatial patterns which are composed of relatively homogeneous smaller-scale areal classes for the purpose of reducing the inherent complexity of the spatial arrangement of earth surface features. Regionalization -- grouping or clustering of areas of similar attributes -- represents only a special, or extended type of classification.

Many attempts have been made in a variety of natural sciences to classify or order information about ecological systems. One of the most 
striking features of the classifications is the number and types of arrangements that have been proposed. However, classifications of natural systems do have some attributes in common. First, they are an intellectual attempt to simplify and/or clarify the complex relationships between ecosystem components and processes. Natural systems in their entirety are often too intricate, in a synoptic sense, to understand completely. Secondly, all classification schemes have a particular purpose. The purpose for which the classification is intended determines both its form and the information used in its construction. In some cases, the classification is expected to produce groups with enough characteristics in common so that a word or number will enable a person who cannot become familiar with every item to glean some information representative of those items. Finally, all classification schemes are based on subjectively chosen criteria by which phenomena are classified. The objective of the classification and the relevance of the criteria help to determine these initial choices. The ultimate test of any classification, of course, is to determine the degree to which it actually represents reality.

The physical environment exists as a complex of soil, water, topography, climate, geology, and vegetation; components that operate in combination and concert with one another. Through the principles of classification, environmental variability can be expressed in terms of those combinations of features that are thought to be significant and/or of practical value to meet a specific purpose. Classification criteria should be selected from various characteristics of the major land and water components on the basis of their effectiveness for indicating 
ecosystem process and form and human use potential.

\section{REVIEW OF LAND-TYPE CLASSIFICATION}

Depicting patterns of land has been recognized as being especially usefur as a basis for subsequent interpretations and assessments of productivity, land use, and land suitability for various intensities of use (Lacate 1961; Bailey, et al. 1978; Lotspeich 1980; Lotspeich and Platts 1982; and Omernik and Gallant 1986). The classification of land in terms of those components appearing to represent the most important aspects of the physical environment has been the basis for depicting land patterns.

One approach to land-type classification is taxonomy; grouping objects or sites with similar characteristics into defined classes. The technique, used in developing a taxonomic system, according to Bailey, et al (1978) involves four steps: 1) sampling many characteristics of objects or sites; 2) analyzing the characteristics by a variety of [statistical and visual] techniques; 3) considering alternative groupings and selecting a grouping apppropriate to the purpose; and 4) defining the classes as simply and precisely as possible for uniform application to objects or sites not included in the sampling (p. 651). The objective of taxonomy is to produce levels of heirarchy relating to the objects or sites.

Probably the most familiar application of land-type taxonomic site classification is the soil taxonomy used by the USDA Soil Conservation Service. This classification was developed through a series of seven approximations from 1951 to 1960, with the purpose being to help explain 
the relationships between soils and the factors responsible for their development (Donahue, et al. 1983). The six categories defined by the system are: order, suborder, great group, subgroup, family, and series. In the U.S. system all soils are fitted into 10 orders and 47 suborders. This system provides standards for mapping, naming, and interpreting soils.

A relatively common taxonomic approach to land classification in the U.S. is the "habitat type" classification developed originally by Daubenmire (1952) and as revised by Daubenmire and Daubenmire (1968). This procedure has been used extensively by the USDA Forest Service in inventory assessments (Alexander 1985). Habitat type is the basic unit used in classifying lands based on potential (climax) natural vegetation; habitat type represents, collectively, all parts of the landscape that support, or have the potential of supporting, the same climax vegetation.

Küchler's (1964) map, "Potential Natural Vegetation of the Conterminous United States" at a scale of $1: 13,168,000$, is used widely for broad planning of land resources, and in research. The map is based on only a few characteristics (and these are not defined precisely) and therefore lacks some of the desirable attributes of a taxonomic classification. Nevertheless, it is the only classification that includes a map suitable for evaluating land potential for vegetative production on a national scale. 
REVIEW OF AQUATIC CLASSIFICATION

Lake Trophic State Classification

Determination of surface water quality has been an area of relatively intense study in contemporary water management. Since the turn of the century the gap in knowledge between what was known of the dynamics of in-stream and in-lake water quality and what was communicated to decision-makers has been reduced considerably. By 1927, Naumann had formulated and reported his comprehensive ideas concerning the concept of "trophic state" (Naumann 1927). Carlson (1979) summarizes some of Naumann's most basic and relevant conceptual statements which are incorporated in contemporary ideas of trophic status:

1. The productivity of waters is determined by several factors but primarily by the concentrations of nutrients coming into a lake, and the two most important of these nutrients are nitrogen and phosphorus.

2. There are regional variations in lake productivity which correlate with the geologic structure of a lake's watershed.

3. The amount of nutrients affect not on ty the phytoplankton but also the lake biology as a whole.

4. There are certain evolutionary connections between lakes of the various types.

These four statements are the essence of the trophic state concept. They suggest that the concept includes two basic aspects of lakes as dynamic systems: the stimulus or forcing factor -- the rate of nutrient supply to a lake; and the system response -- changes in a 
lake's biological and/or chemical character. Application of the concept has resulted in a multitude of trophic state indices (TSI) regarding lakes (Table I). Trophic state indices can be typological, single variable, multivariable, or based on primary production. They may focus on nutrients as catalyctic agents in biological lake responses, on transparency values as indicative of particulate concentrations and potential productivity, or on volumetric estimates of chlorophy 11. The rate of oxygen depletion with depth has been used in TSI's, algal biomass densities, and indices of species abundance.

\section{TABLE I}

TYPES OF TROPHIC STATE INDICES DEVELOPED FOR LAKES BY VARIOUS AUTHORS

Author, Year

Reimers, et a). 1955

Hayes and Anthony, 1964

Ryder, 1965

Sakamoto, 1966

Vollenweider, 1968

Rodhe, 1969

Vallentyne, 1969

Shannon and Brezonik, 1972

Nat. Acad. Sci., 1972

Bortelson, 1974

Dobson, 1974

U.S EPA, 1974

Uttormark and Wa11, 1974

Likens, 1975

Wetzel, 1975

Carison, 1977

\section{Index Type}

LCI

AP

AP

TSI

TSI

AP

TSI

MVI -TSI

TSI

LCI

TSI

MVI

LCI

AP

TSI

TSI
Approach

IL

IL

IL

IL

NLM

IL

NLM

IL

IL

IL

IL

IL

IL

IL

IL

IL

where: TSI = Trophic State Index

LCI = Lake Condition Index

$A P=$ Areal Productivity

IL $=$ In-Lake approach

NLM = Nutrient Loading Model

From: Shapiro (1975) and Cartson (1979) 
To further illustrate the extent of the attempts to discretely quantify the terms oligotrophy, mesotrophy, and eutrophy on the trophic scale, values for trophic state limits are shown, as proposed by various authors (Table II). The values given are transformed to standard units using the Carison Trophic State Index to provide a uniform basis for comparison (Carlson 1977). It is clear that the terms themselves are only descriptive measures of water quality -- their limits are not quantifiably agreed upon -- and they are only useful for comparative purposes on a lake-to-lake basis and should be restricted to a very general usage.

\section{TABLE II}

QUANTITATIVE TROPHIC STATE LIMITS PROPOSED BY VARIOUS AUTHORS BASED ON CLOROPHYLL-A, TOTAL-PHOSPHORUS, AND WATER TRANSPARENCY

\begin{tabular}{|c|c|c|c|}
\hline Author /Parameter & 01igotrophic & Mesotrophic & Eutrophic \\
\hline CHLOROPHYLL-A & & & \\
\hline $\begin{array}{l}\text { Sakomoto, } 1966 \\
\text { (TSI) }\end{array}$ & $\begin{array}{l}0.3-2.5 \\
(19-40)\end{array}$ & $\begin{array}{l}1-15 \\
(31-57)\end{array}$ & $\begin{array}{l}5-140 \\
(46-79)\end{array}$ \\
\hline $\begin{array}{l}\text { Vallentyne, } 1969 \\
\text { (TSI) }\end{array}$ & $\begin{array}{l}<5 \\
(46)\end{array}$ & $\begin{array}{l}5-10 \\
(46-53)\end{array}$ & $\begin{array}{l}>10 \\
(>53)\end{array}$ \\
\hline $\begin{array}{l}\text { Nat, Acad. Sci., } \\
1972 \text {, (TSI) }\end{array}$ & $\begin{array}{l}<4 \\
(<44)\end{array}$ & $\begin{array}{l}4-10 \\
(44-53)\end{array}$ & $\begin{array}{l}>10 \\
(>53)\end{array}$ \\
\hline $\begin{array}{l}\text { Dobson, } 1974 \\
\text { (TSI) }\end{array}$ & $\begin{array}{l}<4.3 \\
(<45)\end{array}$ & $\begin{array}{l}4.3-8.8 \\
(45-52)\end{array}$ & $\begin{array}{l}>8.8 \\
(>52)\end{array}$ \\
\hline U.S. EPA, 1974 & $<7$ & $7-12$ & $>12$ \\
\hline
\end{tabular}


TABLE II (continued)

\begin{tabular}{|c|c|c|c|}
\hline Author/Parameter & igotrophic & Mesotrophic & Eutrophic \\
\hline \multicolumn{4}{|l|}{ TOTAL-PHOSPHORUS } \\
\hline $\begin{array}{l}\text { Sakomoto, } 1966 \\
\text { (TSI) }\end{array}$ & $\begin{array}{l}2-20 \\
(14-47)\end{array}$ & $\begin{array}{l}10-30 \\
(37-53)\end{array}$ & $\begin{array}{l}10-90 \\
(37-69)\end{array}$ \\
\hline $\begin{array}{l}\text { Vol lenweider, } 1968 \\
\text { (TSI) }\end{array}$ & $\begin{array}{l}5.0 \\
(27)\end{array}$ & $\begin{array}{l}10-30 \\
(37-53)\end{array}$ & $\begin{array}{r}30-100 \\
(53-71)\end{array}$ \\
\hline $\begin{array}{l}\text { U.S. EPA, } 1974 \\
\text { (TSI) }\end{array}$ & $\begin{array}{l}<10 \\
(<37)\end{array}$ & $\begin{array}{l}10-20 \\
(37-47)\end{array}$ & $\begin{array}{l}>20 \\
(>47)\end{array}$ \\
\hline \multicolumn{4}{|l|}{ TRANSPARENCY } \\
\hline $\begin{array}{l}\text { Vallentyne, } 1969 \\
\text { (TSI) }\end{array}$ & $\begin{array}{l}>6 \\
(<34)\end{array}$ & $\begin{array}{l}3-6 \\
(34-44)\end{array}$ & $\begin{array}{l}<3 \\
(>44)\end{array}$ \\
\hline $\begin{array}{l}\text { U.S. EPA, } 1974 \\
\text { (TSI) }\end{array}$ & $\begin{array}{l}>3.7 \\
(<41)\end{array}$ & $\begin{array}{l}3.7-2.0 \\
(41-51)\end{array}$ & $\begin{array}{l}<2.0 \\
(>50)\end{array}$ \\
\hline
\end{tabular}

From: Carlson, 1979

Lake-Watershed Classification

While contemporary lake water quality studies and trophic state determinations often utilize watershed factors in their classification schemes, most are concerned with the lake itself and do not address the importance of the watershed. The outputs of water as runoff, dissolved nutrients, and other chemicals and particulate matter from the watershed are the main inputs to lakes, are some of the most important land-water linkages in the biosphere (Likens and Bormann 1974, p. 447). The magnitude, timing, and duration of these watershed outputs are, in large part, determined by watershed characterictics. The classification of watershed characteristics may be employed to distinguish between different watersheds in contrasted areas and further, in those watersheds draining toward lakes, the differences in lake responses may be attributed partiy to differences in those watershed characteristics 
(Gregory and Walling 1973).

The ecosystem-watershed concept (0'Sullivan 1979) represents a method of integrating the hydrologist's approach of using the topographic watershed as the basic operational unit with the biologist's approach of using the ecosystem as the basic operational unit. The studies cited below express the basic tenet that the biogeochemical character of any lake, therefore its productivity, is closely related to the biogeochemistry of its watershed.

Hutchinson (1969) suggests that instead of classifying lakes in terms of oligotrophy and eutrophy, the watershed-lake-sediment system should be classified. This "external" systems perspective has the advantage of being independent from in-lake processes. Carlson (1979) states that this approach "would free the trophic concept from its historical and technical encumberances that have frustrated the development of simple, uniform classificatory techniques" (p. 11).

Lotspeich (1980) outlined the main points which should be considered when a watershed classification is being developed. The outline is based on the assumption that the watershed of a stream or lake is the controlling land unit on the ecologic character of that stream or lake, and that macroclimate and geology are the primary factors determining biogical productivity, the nature of soils and vegetation, and the morphology of streams and lakes in a watershed.

Winter (1977) developed a classification of the hydrologic settings of lakes in the North Central United States. He evaluated 150 lakes of North Dakota, South Dakota, Minnesota, Wisconsin, and Iowa for the purpose of classifying them according to their interchange with 
atmospheric-water, surface-water, and groundwater. The results of the study were maps of the distribution of the most important independent variables related to the hydrologic settings of the lakes (Figure 2). In this respect, this study presents a much broader approach to classifying lake-watershed ecosystems than has been used in most previous studies.

Water quantity deficits and demands in the arid southwestern U.S. prompted Fletcher and Rich (1955) to classify watersheds in terms of hydrologic surface discharge. By using temperature and precipitation data together with runoff and water-use information for Arizona, New Mexico, and Western Texas, watershed attributes were extrapolated to similar areas within the larger region and a map of low, intermediate, and high water yielding areas was generated. This concept of watershed classification, based on precipitation and potential evapotranspiration provides a practical approach to arid-land water planning where conservation of available surface water is critical for irrigation, industrial, and domestic use.

West Malaysian watersheds were classified by Eyles (1971) for the purpose of demonstrating that regional description and classification can be improved objectively by the use of parametric techniques of land classification. In this study, Eyles selected 410 fourth-order drainage areas and determined values for five parameters for each watershed: watershed area, watershed relief, average watershed slope, drainage density, and the hypsometric integral. The data for the five morphometric variables were then used in a cluster analysis to form a number of "natural groups". The cluster analysis also established the 
nodal character of each group rather than the boundary values (p. 467). The end result is the generation of six general watershed types, which, the author proposes, could provide a framework for further morphometric and hydrologic research.

\section{ECOREGIONAL CLASSIFICATION}

Ecosystems exist at many scales, and the integration and synthes is of knowledge about physical and biological components of ecosystems is fundamental to the evaluation of ecosystem responses to natural processes and human use. Regions of relative ecosystem homogeneity have been developed to give perspective to these integrations at macroscales. These have been termed "ecoregions" and they are defined as large geographic zones that represent a number of geographical groups or associations of similarly functioning, smaller ecosystems (Omernik and Gallant 1986). Ecoregions in their most basic form delimit smaller systems that recur throughout a region by discriminating between different spatial patterns or associations of site specific ecosystems.

Ecoregions have four important functions for research and management. First, ecoregions provide a geographic framework in which the operation and responses of an observed ecosystem may be expected to also occur in a similarly defined, unobserved ecosystem. This aides in the formulation and application of management policies and the implementation of management programs on a region-wide basis, rather than for each individual site. Second, potential ecosystem condition can be better assessed given a region of relative environmental homogeneity. In addition to site-specific data and information, state 
and regional land and water managers need a regional method for assessing the status of the ecosystems or ecosystem components for which they are responsible. Third, the ecoregion model provides a means to classify terrestrial and aquatic ecosystems. Since ecoregions are defined on the basis of similarly functioning systems, ecologically sound and comprehensive management and research goals can be developed for an entire ecosystem regardless of administrative or political boundaries which may or may not coincide with an ecoregion boundary. Fourth, determination of "typical" ecosystems and/or reference sites within ecoregions can be effectively used to establish long-term programs for monitoring and/or restoration of ecosystems on a regional scale.

One of the first steps for the evaluation of ecosystems in a regional context is the development of ecoregion maps. In the United States, attempts to divide the entire country into ecological regions has been ongoing (Allen 1892; Merriam 1898; Dice 1943; Bailey 1980; and Omernik 1987). Ecoregional classification has been applied at more detailed levels in various parts of the country. In Montana, Arno (1979) delineated forest regions for the state based on climate, soils, and species composition. In the Pacific Northwest, Franklin (1965) produced eleven ecological provinces for use in characterizing True fir-Hemlock forest areas in the mountainous portions of western Oregon and Washington. The author based the divisions on differences in geology, topography, soil parent materials, climate, and forest composition.

Larsen, et al. (1986) divided the state of Ohio into four aquatic 
ecoregions based on the spatial patterns resulting from the combinations of land-surface form, potential natural vegetation, land use, and soil parent material. Regional differences in fish assemblages were then compared to the ecoregional patterns. Heiskary, et al. (in press) also employed the aquatic ecoregion approach, identically defined as in Larsen, et al. (1986), as a basis for evaluating the spatial patterns in lake characteristics in Minnesota as they relate to potentially attainable lake trophic status. Ecoregions of the upper-Midwest states of Minnesota, Wisconsin, and Michigan were used to extrapolate lake alkalinity data throughout the region (Griffith, et al., in press). The authors' purpose was to assess the relative potential sensitivity of lakes and to develop a means toward more accurate regional assessment of the effects of acid deposition on water resources of the area.

A map of ecoregions for Oregon, Washington, and Idaho has been compiled by Omernik and fallant (1986). The ecoregions are based on overlapping patterns of land use, land-surface form, potential natural vegetation, and soils. The intended use of this map is to help water researchers and managers better understand the regional patterns of ecosystem quality and the relative importance of factors that may be determing this quality (Omernik and Gallant 1986, p. 1). This map is the model used to compare the resultant statistical groupings of lake-watershed ecosystems used in this thesis.

Ten ecoregions are identified for Oregon (Figure 2; Table III). Two of these, the Puget Lowland and Northern Bas in and Range ecoregions, represent only very small areas with in the state. The remaining eight ecoregions, combined, cover over ninety percent of the state's area. 
Each ecoregion is subdivided into two sub-units: the "most typical" areas, where there is the greatest overlap between the four factors characterizing the ecoregions; and the "generally typical" areas that do not share as high a correspondence in the defining attributes. Seven of the eight ecoregions contain lake-watershed ecosystems used in this thes is (Figure 3).

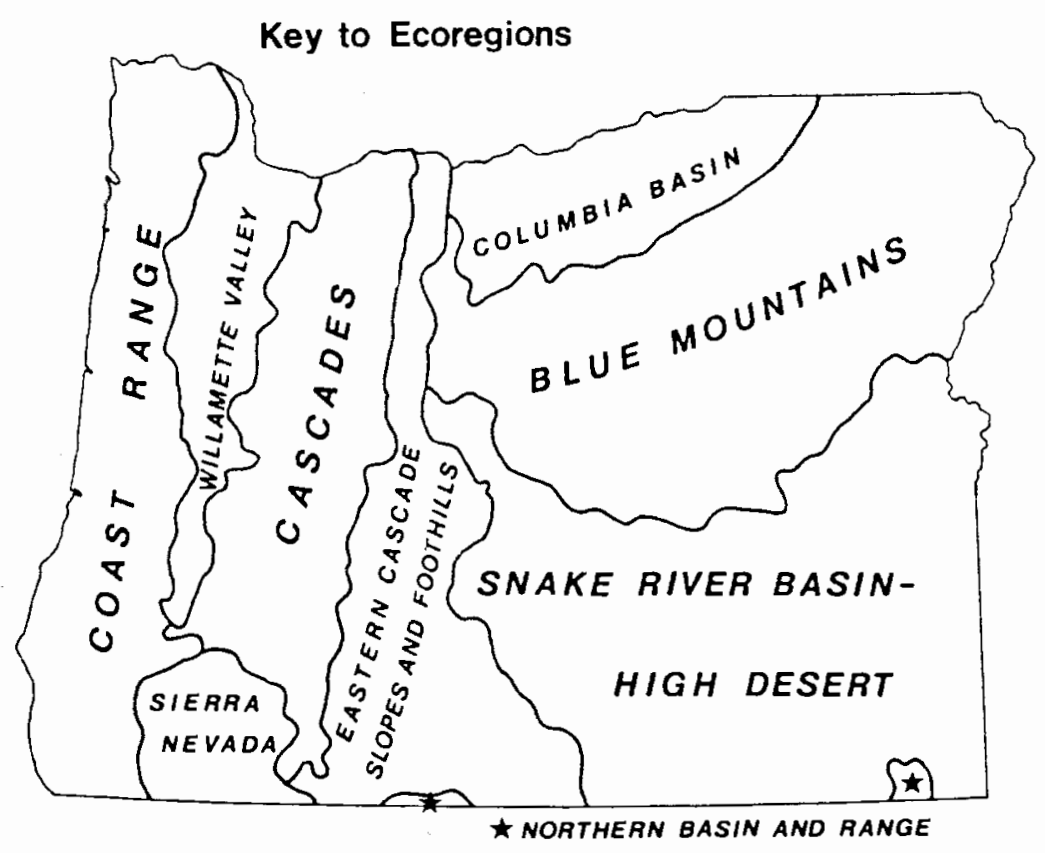

Figure 2, Oregon Ecoregions. 
TABLE III

CBARACTERISTICS OF ECOREGIORS IN TAE PACIFIC MORTEUEST

\begin{tabular}{|c|c|c|c|c|}
\hline E00rब8100 & $\begin{array}{l}\text { Land Surface- } \\
\text { rorm }\end{array}$ & $\begin{array}{c}\text { Potent1al retural } \\
\text { Pegetatioa }\end{array}$ & $\begin{array}{r}\text { Lend } \\
\text { Oee }\end{array}$ & 50110 \\
\hline $\begin{array}{l}\text { COAST } \\
\text { RAXGB }\end{array}$ & $\begin{array}{l}\text { Low to b18h } \\
\text { qounta1ns }\end{array}$ & $\begin{array}{c}\text { Spruoe/cedar/benlook, } \\
\text { odar/bendook/ Douglas- } \\
\text { elr, rodwood }\end{array}$ & $\begin{array}{c}\text { Foreet and woodland } \\
\text { motig ungrased }\end{array}$ & 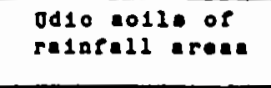 \\
\hline $\begin{array}{l}\text { PUGET } \\
\text { LOYLAND }\end{array}$ & 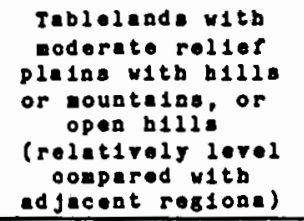 & $\begin{array}{l}\text { Cadar/bonlook/ } \\
\text { Douglab-r1r }\end{array}$ & $\begin{array}{l}\text { Hosalo inoluding } \\
\text { foreat, voodland, } \\
\text { pestura, and } \\
\text { oropland }\end{array}$ & 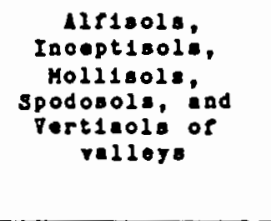 \\
\hline $\begin{array}{l}\text { WILLAMETTE } \\
\text { VALLET }\end{array}$ & $\begin{array}{c}\text { Pla las witb billa } \\
\text { or open billa }\end{array}$ & 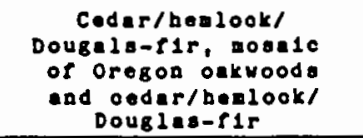 & $\begin{array}{l}\text { Enpbasis on orop- } \\
\text { land witb sone } \\
\text { lntersperaion of } \\
\text { pature, woodlend, } \\
\text { and roreat }\end{array}$ & 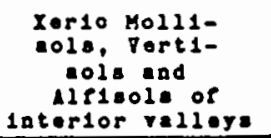 \\
\hline $\begin{array}{l}\text { SIERRA } \\
\text { YETADA }\end{array}$ & B1gh nountalas & $\begin{array}{l}\text { Hixed oonifer rorest } \\
\text { (f1r, pine, Douglase } \\
\text { fir), red fir, } \\
\text { lodgepole pinel } \\
\text { aubalplne rorest } \\
\text { (howlook) }\end{array}$ & $\begin{array}{c}\text { Forest and yoodland } \\
\text { grazed }\end{array}$ & $\begin{array}{l}\text { oltiogla } \\
(x \in r u l t a)\end{array}$ \\
\hline CASCADES & f1gb wountalas & 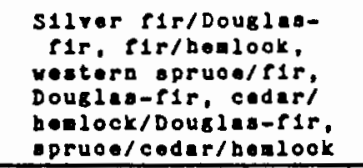 & $\begin{array}{l}\text { Forest and woodlend } \\
\text { mostly ungrazed }\end{array}$ & $\begin{array}{l}\text { odic oo11a } \\
\text { of high rain- } \\
\text { rald gountaing }\end{array}$ \\
\hline $\begin{array}{l}\text { EASTERY } \\
\text { CASCADES } \\
\text { SLOPES } \\
\text { AHD } \\
\text { FOOTEILLS }\end{array}$ & 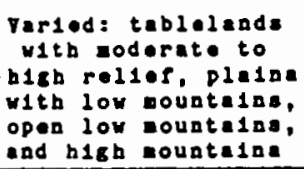 & $\begin{array}{l}\text { Wetern ponderose } \\
\text { plae }\end{array}$ & $\begin{array}{l}\text { Forat und woodland } \\
\text { grased }\end{array}$ & $\begin{array}{l}\text { Iorio solls or } \\
\text { eoderaterain- } \\
\text { rall areas }\end{array}$ \\
\hline $\begin{array}{l}\text { COLDKBIA } \\
\text { BASIJ }\end{array}$ & 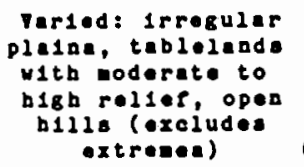 & $\begin{array}{c}\text { Wheatgrase, } \\
\text { bluegrass } \\
\text { feacuef } \\
\text { whetgrasa, } \\
\text { acebrusb atoppe } \\
\text { (segebrusb, wbetgrasa) }\end{array}$ & $\begin{array}{l}\text { Hotly oropland, } \\
\text { oroplend ulth } \\
\text { graeing land }\end{array}$ & $\begin{array}{l}\text { Ierolla, } \\
\text { Channeled } \\
\text { Soablanda }\end{array}$ \\
\hline $\begin{array}{l}\text { BLOE } \\
\text { MODNTAIRS }\end{array}$ & $\begin{array}{l}\text { loy to h1Eb } \\
\text { open nountalna }\end{array}$ & 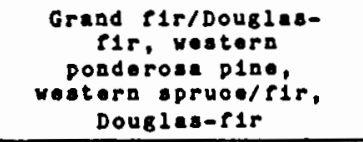 & $\begin{array}{l}\text { Forest and woodland } \\
\text { grazed }\end{array}$ & 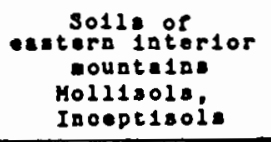 \\
\hline $\begin{array}{l}\text { SHAXE RIVER } \\
\text { BASIK/ } \\
\text { HIGH DESERT }\end{array}$ & $\begin{array}{l}\text { Tablelando with } \\
\text { moderate to bigh } \\
\text { relief plaigs } \\
\text { with hilis or low } \\
\text { vountalas }\end{array}$ & $\begin{array}{c}\text { Segebruab steppe } \\
\text { (esgobrusb, wbet- } \\
\text { grass), altbrusb/ } \\
\text { greasewood }\end{array}$ & $\begin{array}{c}\text { Desert abrublend } \\
\text { grazed, cobe } \\
\text { Irrignted agrioulture }\end{array}$ & $\begin{array}{c}\text { Ar1d1001: arid10 } \\
\text { Mol11:ole }\end{array}$ \\
\hline
\end{tabular}

- Source: owera1k and Gallant 1986

- Table generated on "SOPERCALC-3" apreadobet progran 


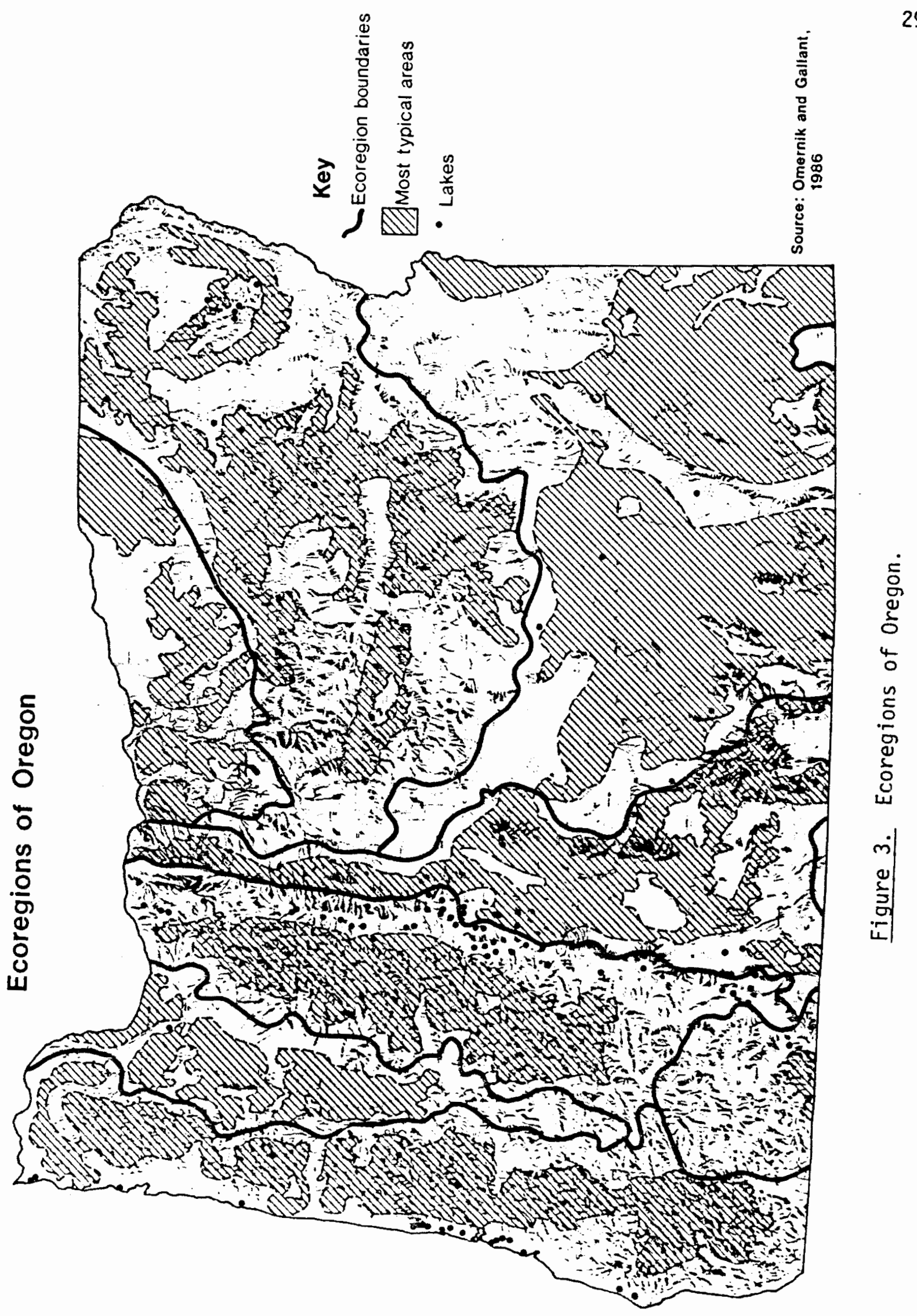




\section{CHAPTER IV}

\section{OREGON LAKE-WATERSHED ECOSYSTEMS}

A total of ninety-eight lake-watershed ecosystems were selected for analys is and comparison in this paper (Figure 4). The lakes selected were primarily natural in origin, although seven are true reservoirs formed as the result of the artificial damming of stream valleys. These seven impoundments were included to provide a more complete sample and uniform distribution of lakes around the state. Fourteen of the lakes selected are natural lakes modified by the installation of low dams at their outlets. The primary source document for much of the data used herein is the Atlas of Oregon Lakes Johnson, et a1. 1985). This publication is a synthes is and compilation of much of the physical, biological, and chemical data that exists for over 200 of the larger and/or better-known lakes and reservoirs in Oregon.

\section{VARIABLE SOURCES, DEFINITIONS, AND EXPLANATIONS}

A set of twenty-four variables was selected to represent the most complete picture of each lake-watershed ecosystem's morphometry, hydrology, limnology, and human use characteristics (Table IV). Quantities represent the most current and best available measurements and were taken from several sources (Table V). The complete data matrix is presented in Appendix A. 


\section{Selected Lake - Watershed Ecosystems}

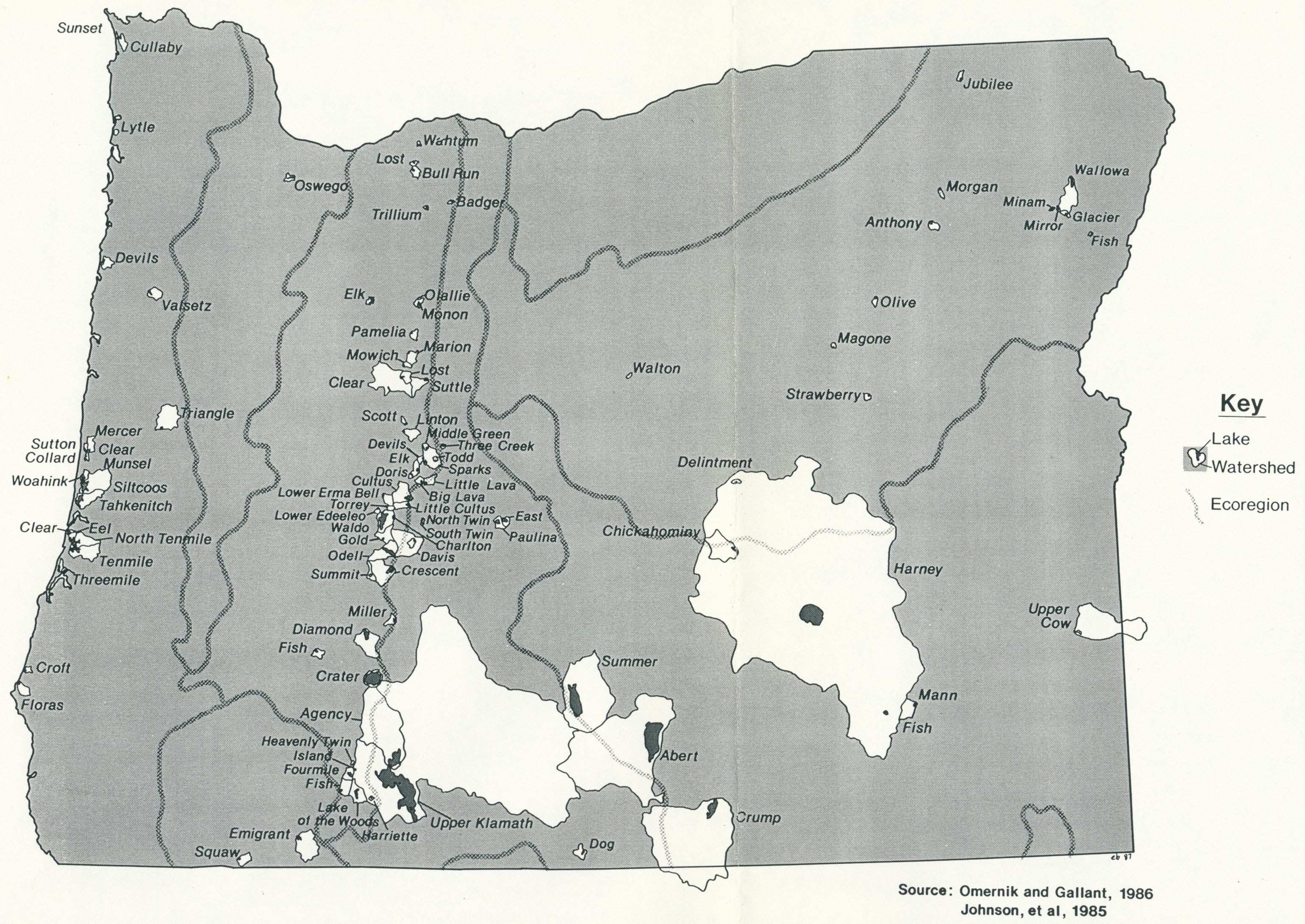


TABLE IV

VARIABLE DESCRIPTIONS

\# Variable

1. Elevation

2. Avg. Annual Precip.

3. Watershed Area

4. Drainage Basin Ratio

5. Avg. Annual Runoff

6. Theoretical Retention Time TRt

7. Mean Annual Flood

8. Avg. Sediment Yield Land Use

9. Forest

10. Agriculture

11. Urban

12. Range

13. Water

14. Other

15. Lake Area

16. Average Depth

17. Max imum Depth

18. Lake Volume

19. Secchi Disk Depth

20. Areal Total Phosphorus
Abbrv.

ELEV.

PRECIP

$A(B)$

$\mathrm{OBr}$

RO

MAF

SDY

LU(F)

$L U(A G)$

LU(U)

LU(R)

LU(W)

$\operatorname{LU}(0)$

$A(L)$

Ave. $z$

Max. Z

v

SD

A-Tp
Units

feet

inches

square miles

ratio $A(L) / A(B)$

inches

years

cfs

tons/yr

$\%$ of Basin Area

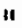

II

II

II

II

square miles

feet

feet

acre-feet

feet

$\mathrm{mg} / 1$ 
TABLE IV (continued)

\begin{tabular}{|c|c|c|c|}
\hline \# & Variable & Abbrv. & Units \\
\hline 21 . & Total Phosphorus & $T p$ & $\mathrm{mg} / \mathrm{l}$ \\
\hline 22 . & Chlorophyll a & CHLPHLa & ug/ 1 \\
\hline 23. & Alkalinity & ALK & ppm \\
\hline 24. & Morphoedaphic Index & MEI & ratio \\
\hline
\end{tabular}

TABLE $V$

VARIABLE EXPLANATIONS

\section{Variable}

1. Elev

2. Precip

3. $A(B)$

4. $\mathrm{DBr}$

5. RO

6. TRt

7. MAF

8. SDY

9-14. LU

\section{Source}

Johnson, et al. 1985;

USGS topo. Quads.

Johnson, et al. 1985; State Wat.Res.Dept., River Bas in Reports

Johnson, et al. 1985; USGS topo. Quads.

$A(B) / A(L)$

USSCS, $1931-1960$.

Author; Phillips, et a 1. 1971; USEPA/NES Working Papers 833, 834

USGS Wat. Sup. Pap. 1685,1686,1689; Gregory and Walling 1973

USSCS; Oregon DEQ. Johnson, et a l. 1985; State Wat.Res.Dept., River Basin Reports
Method of Measurement

Height above MSL

Weighted avg. over watershed

Digital area planimetry Lake Area / Watershed Area Weighted avg. over watershed Lake Volume / Avg.Ann. Runoff

Mult. Regression Equations, Areal Discharge Graphs

Digital area planimetry

Digital area planimetry 
TABLE $V$ (continued)

\begin{tabular}{|c|c|c|c|}
\hline \multicolumn{2}{|c|}{ Variable } & \multirow{2}{*}{$\begin{array}{l}\text { Source } \\
\text { Johnson, et a T. 1985; } \\
\text { various air photos } \\
\text { and USGS Surface- } \\
\text { Water Records }\end{array}$} & \multirow{2}{*}{$\frac{\text { Method of Measurement }}{\text { Digital area planimetry }}$} \\
\hline 15. & $A(L)$ & & \\
\hline 16. & Ave $z$ & Johnson, et a 1. 1985 & Digital lake bathymetry \\
\hline 17. & $\operatorname{Max} Z$ & Johnson, et a 1. 1985 & Digital lake bathymetry. \\
\hline 18. & V & Johnson, et a1. 1985 & Digital lake bathymetry \\
\hline 19. & SD & Johnson, et al. 1985 & Visual average depth \\
\hline 20. & $A-T p$ & Omernik 1977, map. & Weighted avg. over watershed \\
\hline 21. & $T p$ & Johnson, et a1. 1985 & $\begin{array}{l}\text { Vertically integrated sample; } \\
\text { colorimetric technique }\end{array}$ \\
\hline 22. & CHLPHLa & Johnson, et a 1. 1985 & $\begin{array}{l}\text { Vertically integrated sample, } \\
\text { fluorimetric method }\end{array}$ \\
\hline 23. & Alk & Johnson, et a1. 1985 & Dram plot method \\
\hline 24. & MEI & ALK/mean depth. & Lake alkalinity / avg. depth \\
\hline
\end{tabular}

These data were the basis for the statistical generation of similar groups of the selected lake-watershed ecosystems using the multivariate techniques of factor analysis and cluster analysis. The following is a discussion of the variables composing the matrix used in the analysis.

Elevation (elev) and watershed area $(A(B))$ can be considered independent of time -- they do not change except over very long time periods. Lake area $(A(L))$, lake mean-depth ( $A V G Z$ ), maximum lake depth $(\operatorname{MAX} z)$, and lake volume (V) are assumed to be relatively constant on an annual basis, with minor fluctuations seasonally. Other variables such 
as precipitation (PRECIP), runoff (RO), theoretical retention time (TRt), mean annual flood (MAF), sediment yield (SDY), and areal total phosphorus (A-Tp) represent long term averages or are functions of long term averages (e.g. Ro values are annual averages for the period 1931-1960, and TRt values are defined as V/RO). The values for secchi disk depth (SD) and the concentrations for total phosphorus (TP), chlorophy 17-a (CHPHLa), and alkalinity (ALK) are measurements which were taken directly from Johnson, et al. (1985) and are assumed to be representative of summer values, with $\mathrm{Tp}$ and CHPHLa recognized as variables which fluctuate more both seasonally and annually (R.R. Petersen, personal communication).

\section{Elevation}

The elevation of a lake-watershed ecosystem influences the type and duration of physical, chemical, and biological processes operating with in the system, as well as indirectly influencing human activities. In genera1, systems at higher elevations have higher receipts of average annual precipitation (both rainfall and snowfa11), lower average annual and seasonal temperatures, shorter growing seasons, and are often more oligotrophic. Systems at higher elevations are often less accessible to intense human activity, especially those activities detrimental to lake system quality.

In contrast to higher elevation systems, those at low elevations have higher average annual and seasonal temperature regimes, longer growing seasons, and are generally more productive biologically. Chemical weathering at lower elevations assumes a more important role in erosional processes, generating a greater percentage of finer organic 
and inorganic particulates. Most low elevation lakes in Oregon are accessible by motorized vehicles, many have permanent human residents on their watersheds, and there appears to be a connection between lower elevation and eutrophic conditions.

\section{Precipitation}

These values were obtained from State Water Resources maps of individual major river basins and statewide U.S. Soil Conservation Service maps, both showing isopleths of average annual precipitation in inches. A weighted average technique was used to determine areal average values for watersheds through which many precipitation contours pass (Appendix B).

\section{Watershed Area}

Defined as the topographic catchment area which contributes surface water runoff to a lake, watershed areas were determined using digital area planimetry of USGS topographic quadrangle maps and reported in square miles. Only two systems, Sunset and Island Lakes, had indeterminate watershed areas, due to undefinable hydrographic divides. The area of a lake's watershed is a major variable of importance to the study of lake-watershed ecosystems. Larger watersheds collect more precipitation which translates to more runoff and sediment transport, and often, therefore, an increase in nutrient transport to a lake. Watershed area also controls, to a great degree, other hydrologic characteristics such as peak discharge, mean annual flood, and retention time (see discussion below). 
Drainage Ratio

This variable is an index of the interaction of watershed area and lake area, and is of major concern in nutrient loading estimations and determinations of lake trophic status (Ciecka, et al. 1980; Moss 1980, p. 16; Northcote 1980, p. 306; and Goldman and Horne 1983, pp. 90, 352). Large ratios are often highly correlated with average annual runoff values as well as retention time (see discussion below).

\section{Average Annual Runoff}

There is a distinct lack of surface and subsurface runoff data for watersheds containing lakes in Oregon. Of the 98 lakes selected in this study only nine had official government surface water gaging stations within reasonably short distances downstream of the lake outlets. Therefore it was necessary to estimate average annual surface runoff from the watersheds to the lakes. This was accomplished using a 1971 U.S. Soir Conservation Service $1: 2,000,000$ scale contour map of average annual runoff, in inches, for the period 1931-1960 based on U.S. Geological Survey stream gage data for the entire state. Areal averages of mean contour values over the watersheds were used to determine runoff values given as the equivalent depth of water contributed to the lakes. A more complete discussion of the methods used to generate runoff values from the runoff map and an evaluation of their relative accuracy is given in Appendix C.

\section{Theoretical Retention Time}

The theoretical retention time (TRt) of a lake is the amount of time required to completely replace the volume of the lake from inflowing runoff (assuming total circulation). Defined as lake volume 
divided by average annual runoff, this hydrologic measure has direct relations to drainage ratio, nutrient and sediment retention (therefore water transparency), and the mean annual flood of the system. The greater the watershed area is in relation to the size of the lake, the less time it will take for lake volumes to be exchanged. Longer retention times result also in the retention of nutrients which then become available for longer periods for uptake by organisms. For this reason, there is a generally strong positive correlation between theoretical retention time and lake productivity.

Mean Annual Flood

This measure is the average peak discharge, in cubic feet per second, for a given watershed over a period of years, most often defined as the flood with the return period of 2.33 years. This return period value. for mean annual flood has been developed through extensive empirical mathematical observation and is useful in calculating flood frequency curves on a regional bas is for ungaged watersheds (Dunne and Leopold 1978, p. 317).

The significance of the mean annual flood as applied to a study of lake-watershed ecosystems is that it is an integrating, composite measure of many watershed attributes relating the ability of a given watershed to dampen flood maximums -- a measure of a basin's hydrologic transmissivity. Hulsing and Kallio (1964) developed two regression equations for calculating mean annual flood in USGS hydrographic region 14 (Figure 5), one equation for areas west of the Cascade Range crest and one for the east side: 


$$
\begin{aligned}
& \text { West MAF }=0.63 A^{0.95} R^{1.01} L^{-0.13 G} \\
& \text { East MAF }=2.36 A^{0.80} R^{0.62} L^{-0.17} G \\
& \text { where } \quad A=\text { area of watershed (sq.mi.) } \\
& \mathrm{R}=\text { average annual runoff (inches) } \\
& L=\text { area of lakes in watershed (sq.mi.) } \\
& G=\text { a geographic factor derived from the residuals }
\end{aligned}
$$

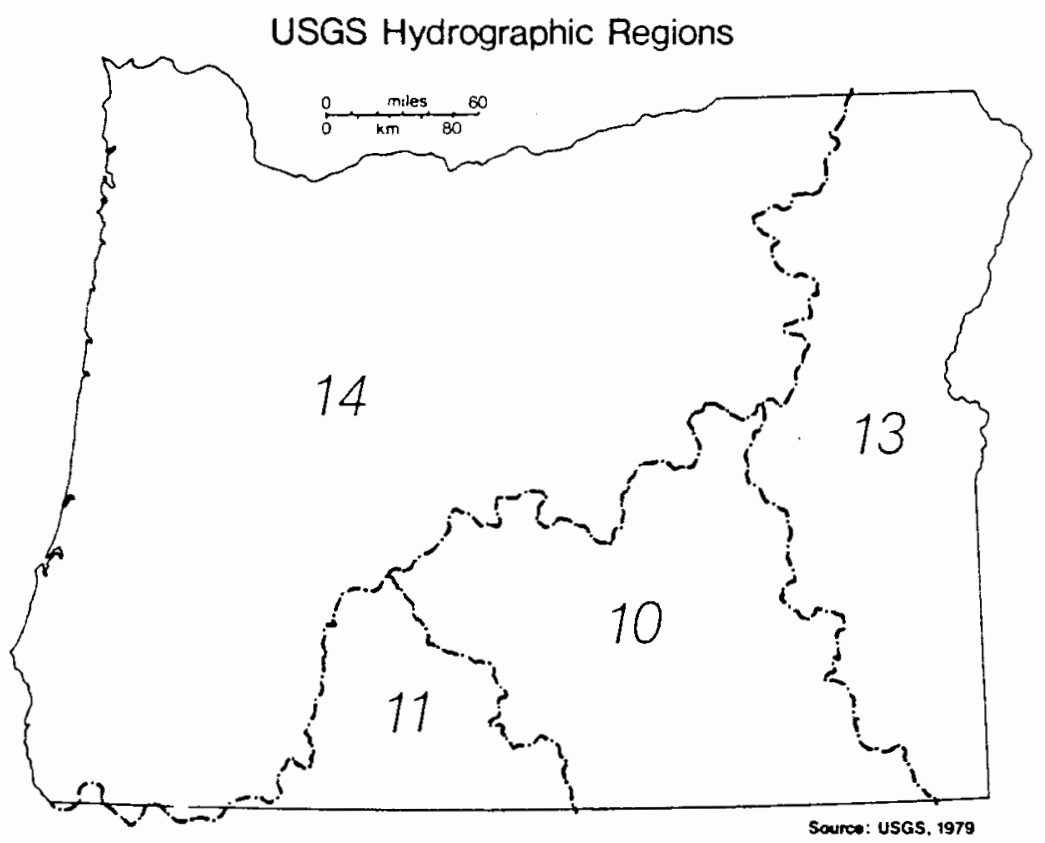

Figure 5. U.S. Geological Survey hydrographic regions.

The equations were used for 69 of the 98 lake systems in this study which are located in the hydrographic region. Values for 6 systems were obtained from graphs (Figure 6) constructed for the calculation of mean annual flood based on USGS Water Supply Papers, as reported in Gregory and Walling (1973, p. 267). The remaining 23 lake systems either did not have significant surface inflow, so MAF was not an applicable measure, or insufficient data was available to satisfy the 
requirements of the regression equations. I

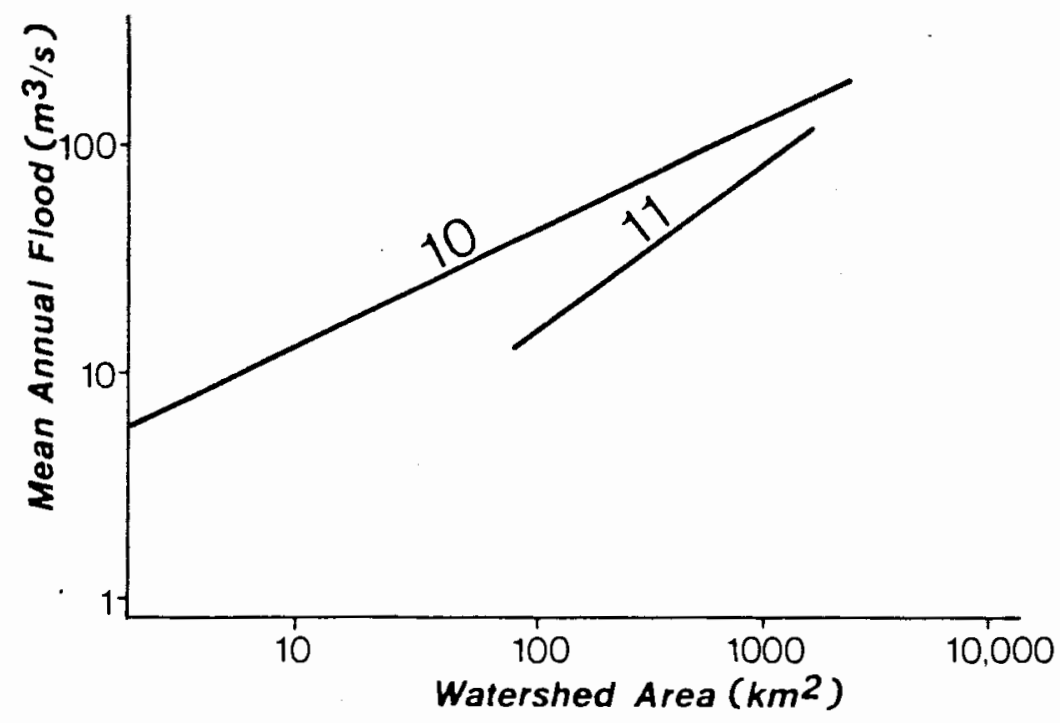

Source: Gregory and Walling, 1973

Figure 6. Mean annual flood calculation graph for watersheds outside USGS region 14.

\section{Average Annual Sediment Yield}

Areas for average sediment yield (SDY), reported in tons per year, were digitized directly from the map compiled by Rickert, et al. (1978) using a weighted areal average. These are sediment yield data converted from the U.S. Soil Conservation Service 1:100,000 map "Sediment Yield Map of Oregon" (1975). The SCS map is based on computer-generated contours of stream sediment data. The values used for digitizing thus represent sediment yields at the sites of measurement extrapolated over the area of the state. They are inclusive of all types of sediment production processes -- gully erosion, mass wasting, sheet erosion, and stream channel erosion. They are not 
indicative of sediment transport. There should be good correlation between SDY and RO, and as Gottschalk (1964) has shown, there may be an inverse relation between $S D Y$ and $A(B)$. This is because smaller watersheds may be dominated by erosional processes, whereas larger catchments often show deposition to be more prominent.

\section{Land Use}

Land use data for the selected watersheds were taken from Johnson, et a1. (1985), and derive from maps published by the oregon Water Resources Department. These maps were a result of the Oregon Statewide Land Use Inventory program conducted from October 1978 to March 1980. Results of the study were compiled for each major river basin in the state. Six categories of major land use were included in the data matrix for this study:

Forest -- lands which are occupied by trees or are used to produce trees on a commercial basis.

Agriculture -- both irrigated and non-irrigated crop and farm lands.

Range -- lands predominantly covered by grasses, shrubs, meadows, unimproved pasture, and scattered trees -especially in the case of juniper and oak cover.

Urban -- residential, commercial, or industrial developments, including schools, parks, and golf courses.

Water -- area of lakes and reservoirs -- including the lake itself.

0ther -- wetlands, snow-ice, lava flows, exposed rock fields and bedrock, sand dunes, quarries, wi lderness areas, and other developed areas not adjacent to urban areas. 
quality. These effects are especially important to consider in terms of the effects on surface erosion and runoff processes and the generation of and/or transport of nutrients to a lake.

\section{Lake Area}

This variable is the surface area in square miles of the lakes as reported in Johnson, et a1. (1985). Lake areas range from a minimum of 0.028 square miles $(0.073 \mathrm{sq} . \mathrm{km})$ at Walton Lake in the Ochoco Mountains, to over 96 square miles (249 sq.km) at Upper Klamath Lake -- the 1argest lake in the state.

\section{Mean Depth}

The mean depth of a lake is a key morphometric measure which is considered to be an indicator of productivity in lakes (Vollenweider 1968; Carlson 1977). Rawson (1955) used mean depth to predict the aquatic food supply and fish harvest of several large lakes in Canada. Northcote and Larkin (1956) used several morphometric parameters, and in particular mean depth, in the development of a productivity index for British Columbia lakes. In general, shallow lakes are often quite productive because their waters are more easily mixed to sediment-depth by wind and currents which may agitate sediments causing the resuspension of deposited nutrients. Bottom waters in deeper lakes are often beyond the mixing-depths of winds and currents and therefore nutrients adsorbed to sediment particles become unavailable for biological uses, resulting in a decreased overall lake productivity.

Maximum Depth

Values for maximum depth were taken from both published and 
original bathymetric maps used in the Atlas of Oregon Lakes (Johnson, et a1. 1985). Except in rare cases, greater maximum depths correspond to greater retention times, greater mean depths, and larger lake volumes.

\section{Volume}

This measure is defined as the sum of the volumes of water between depth contours from the lake surface to its point of maximum depth, reported in feet. Lake volume is thus related to lake area and mean depth. The primary implication of volumetric measures to water quality determination is that a proportionately greater volume of runoff and nutrients must be contributed to a lake having a large volume in order to significantly affect its productivity and/or water retention time.

Secchi Disk Depth

The secchi disk is a tool used to measure water transparency. Values are defined as the maximum visual depth (in feet) at which a standard twelve-inch secchi disk can be seen when lowered into a lake. Secchi disk measures have been used to estimate phytoplankton densities and rates of primary productivity per unit surface area (Deevey 1940; Nygaard 1955; and Ohle 1956). Drawing conclusions from secchi disk-productivity relations has been criticized by some researchers because detecting the secchi disk at maximum visual depth is as much due to the absorption and scattering of light by suspended particulates as it is to chlorophyll only (Edmondson 1980, p. 378). Nevertheless, it can be said that secchi disk values are representative of the depth at which five-percent of light impingent on the surface is transmitted -light which is critical to the production of phytoplankton and 
macrophytes.

\section{Total Phosphorus}

Phosphorus is the most common limiting factor on lake productivity in general and in systems where it is limiting, any additions -- of natural or anthropogenic origin -- can severely influence net lake productivity and overall water quality, aesthetics, and trophic state. The U.S. Environmental Protection Agency, in their evaluation of the National Eutrophication Survey data, has designated phosphorus concentration as a measure of eutrophic status (USEPA 1977, p. 30). The phosphorus data used here were taken from Johnson, et al. (1985) and are in-lake values only. They represent the average phosphorus concentration throughout the water column.

\section{Areal Total Phosphorus}

These data were obtained by digitizing total stream phosphorus concentrations (milligrams per liter), for each watershed, from a map developed by Omernik (1977). The map (Appendix B) was generated using U.S. Environmental Protection Agency/National Eutrophication Survey data on total stream phosphorus and orthophosphorus concentrations, total phosphorus export from drainage areas, land use, flow per unit-area per year, and mean slope (Omernik 1977, p. 24).

With a few exceptions, Takes derive much of their phosphorus concentrations from their respective watersheds via surface and throughflow processes. Although point sources of phosphorus can be significant, e.g. from sewage sources such as septic tank discharge and pit toilets, there are growing efforts to identify and control nonpoint 
source contributions, including agricultural erosion and runoff. Understanding the influence of phosphorus on lake water quality from nonpoint sources can only be gained by incorporating watershed characteristics in water resources research design and in lake management strategies (Figure VI).

Chlorophy11-a

The major pigment of phytoplankton is chlorophyll-a, used primarily to produce chemical energy in photosynthesis. Chlorophyli-a is contained in the green algae, blue green algae, and in the diatoms. Chlorophyll-a values are often positively related to the concentration of the most limiting nutrient and for most systems inversely related to transparency. Concentration values for chlorophyll-a used in this research were taken from Johnson, et al. (1985), reported as a measure of phytoplankton density as employed by Carlson (1977).

\section{Alkalinity}

The alkalinity of water is a measure of the capacity of water to absorb or buffer acid; high alkalinity indicates a high acid neutralizing capacity, low values indicate a greater susceptibility to the effects of added acid. Values for alkalinity used in the data matrix were obtained directly from Johnson, et al. (1985).

\section{Morphoedaphic Index}

Vighi and Chiandani (1985) proposed the morphoedaphic index (MEI) as a means of estimating the natural trophic level of a lake in relation to only lake morphometry and to edaphic factors which depend on the natural characteristics of the watershed. The term "natural trophic 
level" refers to the trophic state a lake would attain were anthropogenic nutrient inputs excluded. Rawson (1955) and Northcote and Larkin (1956) have also suggested the MEI as a means of classifying lakes with regard to their natural trophic state. The values for MEI used in this thesis are the ratio of lake alkalinity/mean depth.

\section{DESCRIPTION OF THE LAKE-WATERSHED ECOSYSTEMS}

The natural lake-watershed ecosystems in Oregon selected for analysis compose a diverse and valuable assemblage of land and water resources. The selected systems occur in only seven of the ten ecoregions identified for Oregon, with over 80 percent of the total 98 systems located in the Cascades, Coast Range, and Blue Mountain ecoregions. The physical, chemical, and biological nature of the chosen lake-watershed ecosystems are determined primarily by the influences of climatic, geologic, and land use factors, each of which varies over wide regional and local scales.

Climate

Climate varies considerably over the state as a consequence of the interplay between prevailing maritime air masses, the more seasonal continental convectional systems, and the topographic influences of mountain ranges and valleys. Large late-fall, winter, and early-spring cyclonic maritime storm systems dominate the climate of most of the state. This regime produces a winter-maximum of precipitation, especially for the areas west of the Cascade Range crest (due to the air-damming effect of the mountains) and the nigher elevations of Eastern Oregon. Late-spring, summer, and early-fall convection cells 
resulting in thunderstorm activity account for much of the annual precipitation in the plateau regions of Eastern Oregon. Because the Coastal and Cascade Mountains are oriented normal to the prevailing westerly flow of winds and moisture, they exert a significant orographic effect on the climate over the lake-watershed systems and their hydrology. There is a general decrease in annual rainfall receipts from north to south and from west to east. Snowfall amounts are among the highest in the country, occurring mainly at higher elevations above 4000 feet $(1211 \mathrm{~m})$. Temperatures are moderated greatly by the prevailing on-shore flow from the Pacific ocean, while in areas east of the Cascades Summer and Fall temperatures have a more continental range.

\section{Geology}

The diversity in surficial geology ranges from the old, mature, folded Tertiary marine deposits and extrusive basalts of the Coast Range (CR) ecoregion, to the broad structural, alluvium filled Willamette Valley (WV) ecoregion. The Cascades (CS) and Eastern Cascades Slopes and Foothills (ESF) ecoregions are composed of a basement shield of primarily Pliocene basalts upon which Quaternary andesitic composite cones are perched. Ancient metamorphosed sedimentary and volcanic materials compose the Sierra Nevada (SN) ecoregion, while the dominant substrates of the Snake River Basin/High Desert (SRB/HD) ecoregion are regional Tertiary and Quaternary basalt flows overlain by glacio-fluvial, lacustrine, and eolian deposits in restricted locales. The complex Blue Mountain (BM) ecoregion is composed of a sequence of folded and faulted uplifts of extrusive basalts, tuffaceous volcanics, a) luvium-filled troughs, and isolated granitic plutons. 
Land Use

The most widespread land use in the state is forestry. Because of ample moisture in all of western Oregon and at higher elevations in eastern regions these areas are dominated by coniferous forest lands. Rangelands, used primarily for grazing of livestock, ranks as the second major land use. The intermediate and lower elevations of eastern Oregon are covered by sub-humid grasslands, semiarid grazing lands, and desert shrublands. Agriculture, both irrigated and non-irrigated cropland, is the third most common land use in the state; it is particularly important in the alluvium-filled WV ecoregion and the loess mantled 1ands of the Columbia Basin (CB) ecoregion.

These are general descriptions of the regional climates and land conditioris in which the selected lake-watershed ecosystems are imbedded. The following is a more specific profile of these systems discussed within the ecoregional context in terms of the variables used in the analys is to characterize them.

\section{Coast Range Ecoregion}

This ecoregion includes the mature, highly eroded, dissected, folded coastal mountains, as well as westward draining river valleys, coastal terraces, and beach-dunal systems. Twenty-one of the 98 selected lake-watershed ecosystems are in this ecoregion; most are found on the coastal margin, with only two actually occurring in the coast Range itself -- Valsetz and Triangle Lakes. The paucity of lakes in the Coast Range, in part, is due to the very heavy annual rainfall ranging from 55-90 inches $(1397-2286 \mathrm{~mm})$ in the western reaches near sea level to over 200 inches $(5080 \mathrm{~mm})$ in the Saddleback Mountain and Sugar 
Mountain area east of Lincoln City. Such high receipts of precipitation coupled with easily eroded substrate account for the relatively rapid infilling of depressions with sediment and/or the erosion of their outlets -- depressions which potentially could hold lakes.

Nineteen of the CR ecoregion lake-watershed systems are associated with coastal dune processes. Many of these lakes originated from the damming of stream valleys by the buildup and inland migration of sand dunes due to glacio-eustacy within the last 27,000 years as a result of the melting of the Pleistocene glaciers. This type of lake-forming process results in a characteristic dendritic shaped lake, examples of which are Mercer Lake (Figure 7), Siltcoos, Tahkenitch, Tenmile, and North Tenmile Lakes. Other lakes in this ecoregion, such as Cullaby, Clear, Collard, and Munsel Lakes, have been formed by the downwarping of coastal terraces across which sand sheets and dunes have subsequently moved and impounded water in interdune areas and against hillslopes.

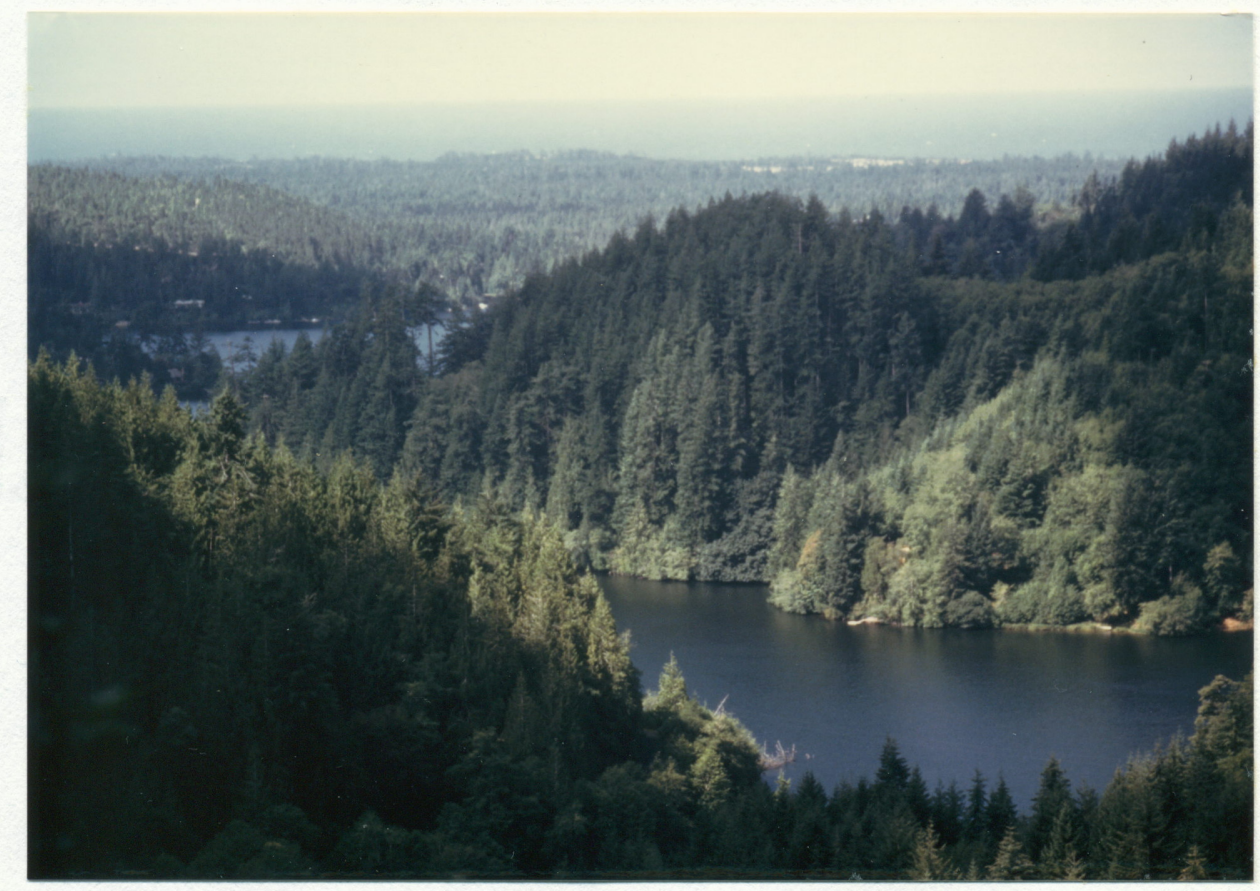

Figure 7. Dendritic Mercer Lake. 
A cluster of 13 lake-watershed ecosystems representative of the coastal margin-type of lakes occur in the ecoregion. These systems are found between the north spit of Coos Bay to just north of the City of Florence. Elevations of these lakes range from 229.0 feet $(69.8 \mathrm{~m})$ at Clear Lake south of Winchester Bay, down to 8.0 feet $(2.4 \mathrm{~m})$ at Siltcoos Lake near Florence. Local relief for this group's watersheds averages $600-700$ feet $(183-213 \mathrm{~m})$, with the maximum elevation reached in the Silcoos watershed at 1840 feet $(561 \mathrm{~m})$. Watershed areas are as small as $0.86 \mathrm{mi}^{2}\left(2.23 \mathrm{~km}^{2}\right)$ for Clear Lake near Florence, to over $67 \mathrm{mi}^{2}(173.5$ $\mathrm{km}^{2}$ ) for Tenmile Lake. Lake areas for these coastal-margin lakes are small, relative to many other lakes in the state, averaging $1.18 \mathrm{mi}^{2}$ $\left(3.07 \mathrm{~km}^{2}\right)$; there are none larger than $5 \mathrm{mi}^{2}\left(12.95 \mathrm{~km}^{2}\right)$. An additional morphometric factor to consider is the mean depth of these systems; the lakes of the $C R$ ecoregion are shallow, with average mean depths at 18.2 feet $(5.6 \mathrm{~m})$. Drainage ratios average 18.2, a somewhat lower than average ratio compared to other lake systems in the data base. However, the mean theoretical retention time for this set of $C R$ ecoregion lakes are among the lowest for the entire state. Heavy annual precipitation and the resulting high runoff values account for this rapid flushing of lake-water, with 71 percent of precipitation translating to runoff to the lakes. These hydrologic and morphometric characteristics are perhaps best supported by the mean annual flood (MAF) values for the lake-watershed ecosystems in this ecoregion. These values range from on $7 y \quad 16.3 \mathrm{cfs}\left(0.46 \mathrm{~m}^{2} / \mathrm{s}\right)$ in the collard Lake system, to $2825 \mathrm{cfs}(79.9$ $\mathrm{m}^{2} / \mathrm{s}$ ) for the Tenmile system. The average MAF value for all the 
lake-watershed systems in the ecoregion is 872.4 cfs $\left(24.7 \mathrm{~m}^{2} / \mathrm{s}\right)$. These, then, are shallow, fast flushing lakes situated in hydrologically quick-response watersheds of relatively low relief and of moderate size.

Sediment yield (SDY) values for the CR ecoregion lake-watersheds have a wide range, from 129 to 20,247 tons/year with mean value of 5137 tons/year. There is a significant difference, however, between the mean SDY and the median value at 2683 tons/year. Over 90 percent of the total SDY for the selected CR ecoregion lake watersheds is accounted for by the upper one-half of the median range, with 70 percent of the total SDY occurring with in the North Tenmile, Siltcoos, Triangle, Tahkenitch, and Tenmile Lakes watersheds. The SDY values reflect the substrate of the watersheds; higher values from the larger areas drain upland residual forest soils; lower values are from the sand-dominated substrate of the smaller dune-impounded lake systems, such as Collard, Threemile, and Lytle Lakes. There also seems to be a relationship between SDY and forest land use for these watersheds. These are predominantly forested catchment areas, with the average watershed having an 80 percent cover of forest land. Watersheds with higher percentages of forest lands are associated with higher SDY values. Beschta (1978) and Swanston and Swanson (1976) found a marked increase in stream sediment load following road building and logging in the timbered areas of the Coast Range. Where other land uses are more pronounced, for example other lakes and ponds or open sand dune areas, SDY values are lower.

By percentage, the watersheds of the selected $C R$ ecoregion lakes are not heavily urbanized. There are isolated residential areas with in 
the catchment areas of Devils Lake, Cullaby, and Woahink Lakes (Figure 8). The highest percentage of urban land in any one watershed occurs in the Sunset Lake system on the north coast $(14 \%)$. This is also the system where the highest in-lake concentration of total phosphorus has been measured (Johnson, et a 1. 1985).

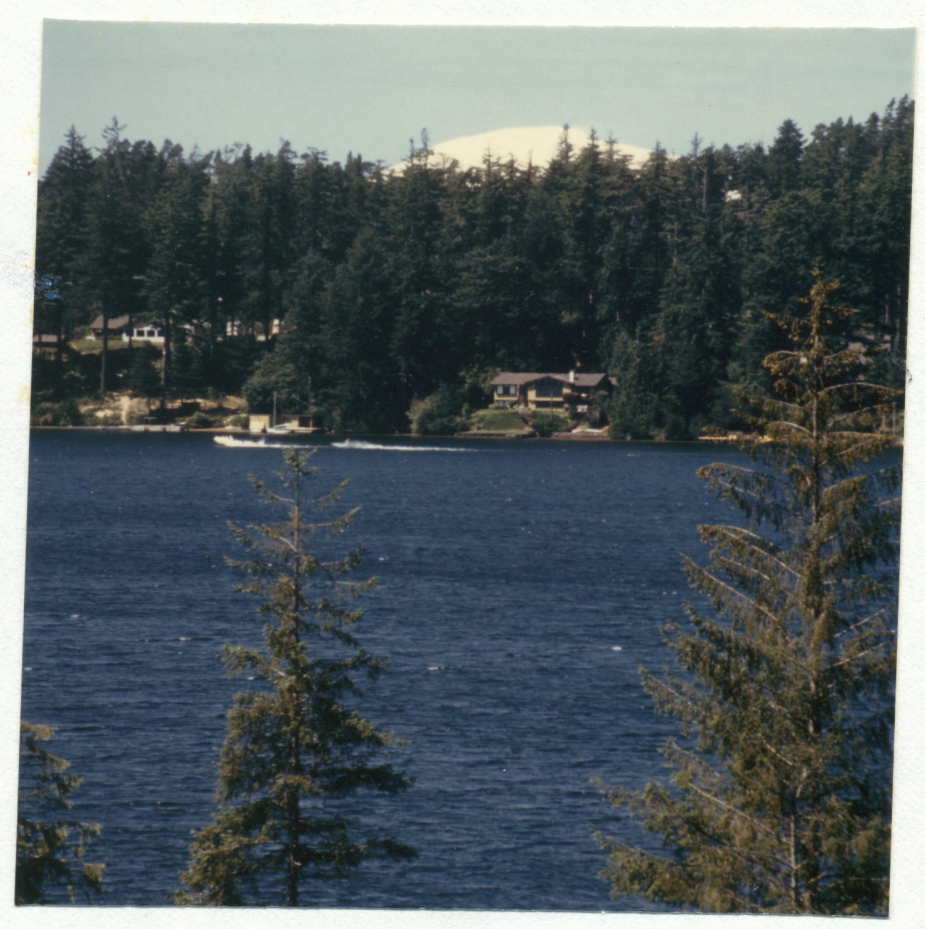

Figure 8. Woahink Lake near Florence.

Willamette Valley Ecoregion

Because only natural lakes were selected, the Willamette Valley (WV) ecoregion is represented in this analysis solely by Oswego Lake. There are other naturally-occurring lakes in the ecoregion, but many of the larger and better-known lakes are not easily defined in terms of the variables used in this study's data base -- primarily the hydrographic measures. Examples of these are the oxbow and flood-scour lakes in the 
Columbia and Willamette River floodplains. It is useful here to discuss the ecoregion's main characteristics to provide a regional setting for comparison purposes, and to describe the watershed and in-lake attributes of Oswego Lake.

The WV ecoregion is a 5310 square mile $\left(13753 \mathrm{~km}^{2}\right)$ structural basin overlain by a mantle of alluvium. Much of the ecoregion encompasses the Willamette River watershed. Low local relief and low elevations characterize the region's topographic form, while runoff and flood potentials are high. Agriculture and urban land uses are the most intensive in the state, in both historic and comtemporary time. The potential natural vegetation is mainly a grassland-coniferous forest association, but a great deal of human influence has altered much of the distribution of natural vegetation.

0swego Lake and its watershed is truly a system dominated by urban land uses. It is one of the few lakes in the state which is monitored and managed by a private lake corporation of land owners. Oswego Lake is also one of the most biologically productive systems in Oregon. Although it is relatively large and deep, with a maximum depth of 55.1 feet $(16.8 \mathrm{~m})$ and a volume which naturally would be sufficiently large to assimilate natural inputs of nutrients, 0swego Lake receives its water from a canal system connected to the heavily degraded Tualatin River. Total-phosphorus concentrations are high at $0.127 \mathrm{mg} / 1$, and a standard secchi disk can be seen only to 5.6 feet $(1.7 \mathrm{~m})$. The lake is highty eutrophic, and current research is underway to assess point and nonpoint source nutrient reduction potential. 
Sierra Nevada Ecoregion

The Sierra Nevada (SN) ecoregion in Oregon is characterized by highly dissected, steep mountains predominantly covered by a mixed coniferous forest -- the primary land use. Local relief is commonly 2000 feet $(609 \mathrm{~m})$ (Omernik and Gallant 1986, p. 21), with a maximum relief of about 7000 feet $(2133 \mathrm{~m})$. Average annual precipitation ranges to 85.0 inches $(2160 \mathrm{~mm})$ in the higher elevations, while interior valleys are quite dry, receiving as low as 18 inches (457 mm) annually. Erosion potential is very high with sediment yields averaging 200-1000 tons per square mile per year -- the higher yields occurring mainly from disturbed upland slopes and erosion of stream banks.

As in the Coast Range ecoregion, lakes are not common in this mountainous area. Emigrant Reservoir, a U.S Bureau of Reclamation impoundment was included to expand the sample size for the SN ecoregion. Only one natural lake in this study is located in the $S N$ ecoregion -Squaw Lake, a naturally formed landslide lake near the headwaters of Squaw Creek near the Oregon-California Border. Squaw Lake, though smal1 in area, $0.072 \mathrm{mi}^{2}\left(0.19 \mathrm{~km}^{2}\right)$, and with a very large $\mathrm{DBr}$ of 262.9 , is classified mesotrophic. However, the MAF value $(608.7 \mathrm{cfs})$ indicates a transmissive watershed, and a TRt of 0.14 years ( 1.68 months) shows that the lake flushes readily.

\section{Cascades Ecoregion}

The Cascades Ecoregion (CS) in Oregon is an area slightiy larger than $11,000 \mathrm{mi}^{2}\left(28,490 \mathrm{~km}^{2}\right)$ composed mainly of the geologically older Western Cascades physiographic province, but also includes the younger 
High Cascades on the eastern margin. The Western Cascades has a mature, dissected topography, with steep ridges and deep stream valleys having narrow flood plains. This is a heavily timbered area with dense forest understories. The High Cascades portion of the ecoregion is an area underlain primarily by andesite capping the regional basalt shield of the Western Cascades. Local relief for the ecoregion is often greater than 3000 feet $(914 \mathrm{~m})$, with most elevations ranging from 2000 to 7000 feet (609-2133 m) (Omernik and Gallant 1986, p. 18).

The Cascade Mountains are a formidable north-south barrier to the prevailing westerly winds and storm systems. Because of this barrier effect, the Cascades ecoregion is an area of climatic, geomorphic, and vegetational transitions. The mountain range is assymetrical with a more gently sloping, concave profile on the west and a steeper east side. Average annual precipitation progressively increases from about 50 inches $(1270 \mathrm{~mm})$ in the lower elevations in the west to over 100 inches $(2540 \mathrm{~mm})$ in the highest elevations.

In general, elevations above 3000 feet $(914 \mathrm{~m})$ were glaciated during the Pleistocene epoch -- a substantial portion of the ecoregion. As a result, numerous depressions were created, many of which are now occupied by Takes. Forty-six of the total 98 lake-watershed ecosystems are found in the CS ecoregion -- the largest concentration of lakes in any area of the state.

Because of the topographic and geologic nature of the western Cascades, few natural lakes are found today in this portion of the ecoregion. Of the selected lakes used in this analysis, only Elk Lake in the Mt. Hood National Forest and Fish Lake in the Umpqua River bas in 
occur as natural lakes in the Western Cascades. Elk Lake, at 3760 feet $(1146 \mathrm{~m})$, is situated in a stream valley which was scoured by a small glacier that deposited a low moraine which now impounds this relatively shallow lake (mean depth of Elk Lake is 12.0 feet or $3.6 \mathrm{~m}$ ). Fish Lake, although at 3405 feet $(1038 \mathrm{~m})$ in elevation, was not created by glacial events, but by a large landslide off the face of Grasshopper Mountain two miles to the south-southwest that impounded Fish Lake Creek (Johnson, et al. 1985). Because the landslide was large, the lake today is quite deep with a mean depth of 61.8 feet $(18.8 \mathrm{~m})$.

The remaining 44 lakes found in the CS ecoregion are in the High Cascades or eastern portion. Glaciation and volcanism are the two lake forming events which occured here. Lakes of glacial origin dominate -26 lakes have been created through simple scouring of bedrock by the ice caps or valley glaciers, impoundment by moraine deposition, or by the sculpting of headwall basins by cirque glaciers.

Typical of the glacial scour lakes are Lower Erma Bell and Lower Eddeeleo Lakes in the forested plateau of the Waldo Lake Recreation Area. This volcanic terrain was modified greatly by the plucking action on bedrock of the glacial ice sheets covering the area during the Pleistocene. Thes two lakes are deep, pocket-like depressions with mean depths of 45.0 feet $(14.0 \mathrm{~m})$ and 70.0 feet $(21.0 \mathrm{~m})$ respectively, with maximum depths of 88.0 feet $(26.8 \mathrm{~m})$ and 123.0 feet $(37.5 \mathrm{~m})$. They are small lakes, with lake areas of $0.66 \mathrm{mi}^{2}\left(0.17 \mathrm{~km}^{2}\right)$ for Lower Erma Bell and $0.16 \mathrm{mi}^{2}\left(0.42 \mathrm{~km}^{2}\right)$ for Lower Eddeeleo Lake. The watershed of Lower Erma Bell Lake is over three times the size of Lower Eddeeleo's - 8.93 $m i^{2}\left(23.1 \mathrm{~km}^{2}\right)$ compared to $2.74 \mathrm{mi}^{2}\left(7.1 \mathrm{~km}^{2}\right)$. Because of the 
differences in watershed areas compared to lake areas, these two system's drainage ratios are quite disparate -- 16.8 for Lower Eddeeleo and 135.3 for Lower Erma Bell. This has significant ties to retention times, sediment yields, secchi disk values, total-phosphorus and chlorophyll-a concentrations, and the morphoedaphic indices. All variables indicate a difference in water quality between the two systems, a view supported by Johnson, et al. (1985).

Lakes dammed by glacial moraines are common in the CS ecoregion. Some of Oregon's most spectacular mountain lakes are of this type, among which are Crescent Lake, Ode 11, and Suttle Lakes. Waldo Lake is impounded by both lateral and terminal moraines (Figure 9), and is one of the clearest, most oligotrophic lakes in North America. Because of their origins, these are large, deep lakes. For example, odell Lake has a surface area of $5.6 \mathrm{mi}^{2}\left(14.5 \mathrm{~km}^{2}\right)$ and a mean depth of 132.0 feet $(40.2 \mathrm{~m})$. Generally, the water quality and trophic status of the moraine-dammed lakes of the CS ecoregion are tied to their drainage ratios, theoretical retention times, and mean lake depths. Suttle Lake is the most eutrophic of this type of lake in the ecoregion having a $\mathrm{DBr}$ of 52.18 , a TRt of 0.24 years (2.88 months), and a mean depth of 11.6 feet $(3.5 \mathrm{~m})$. In contrast, 01 igotrophic Crescent Lake has a mean depth of 124.0 feet $(37.8 \mathrm{~m})$, a 6.5 year TRt, and a DBr of 7.02. Marion Lake (Figure 10) assumes an intermediate water quality status for the glacial moraine lakes for the ecoregion; a mean depth of 64.0 feet $(19.5 \mathrm{~m})$, a $\mathrm{DBr}$ of 33.31 , and a TRt of 0.33 years. 


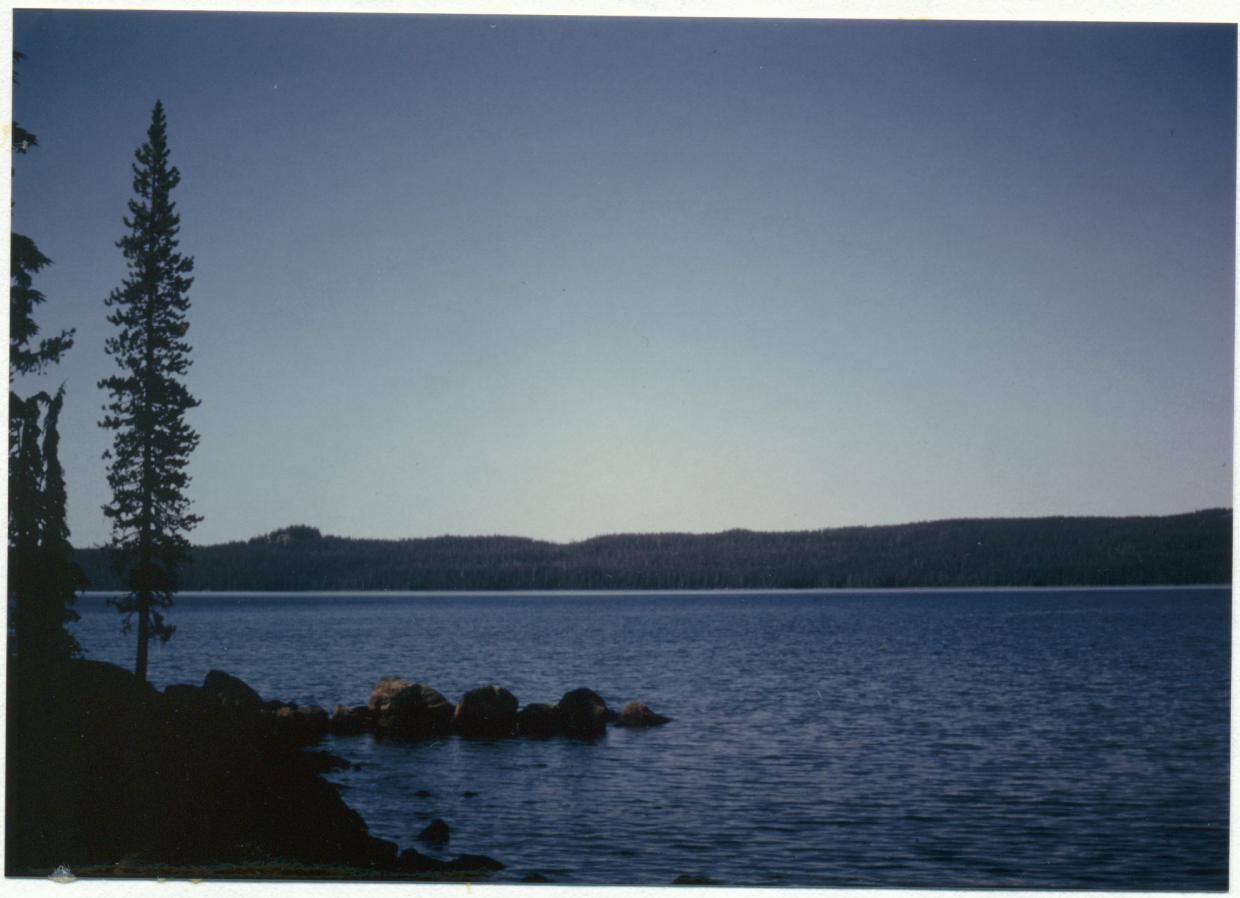

Figure 9. Waldo Lake and impounding moraines.

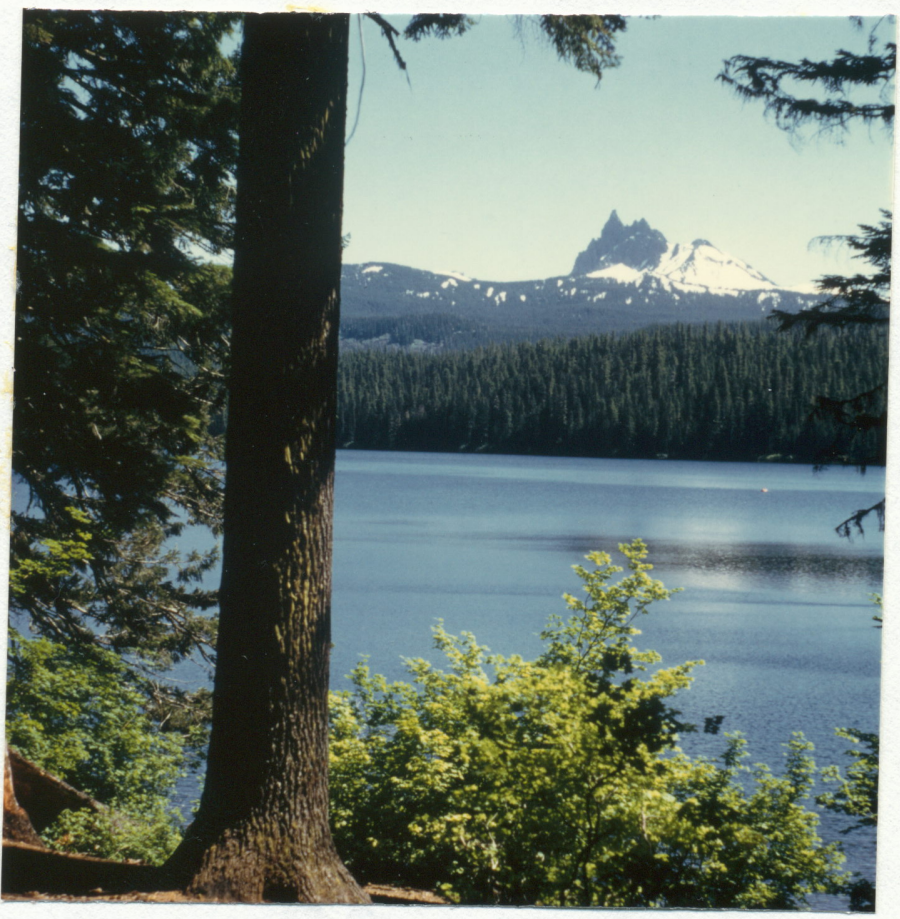

Figure 10. Marion Lake and Three Fingered Jack. 
Glacial cirque lakes, or tarns, are usually the lakes found at the highest elevations. A classic example of a tarn is Harriette Lake in the Mountain Lakes Wilderness Area. At 6750 feet $(2057 \mathrm{~m})$ elevation, Harriette Lake is the highest selected lake within the CS ecoregion. Characteristic of cirque lakes, Harriette Lake's watershed and lake area are small - $0.54 \mathrm{mi}^{2}\left(1.39 \mathrm{~km}^{2}\right)$ and $0.063 \mathrm{mi}^{2}\left(0.16 \mathrm{~km}^{2}\right)$, respectively. For its size, the lake is deep, averaging 35.0 feet $(10.7 \mathrm{~m})$. Also typical of high elevation lakes, Harriette Lake is quite transparent $(S D=55.8$ feet or $17.0 \mathrm{~m})$, and is very low in total-phosphorus $(0.009$ $\mathrm{mg} / 1)$ and chlorophyll-a $(0.2 \mathrm{ug} / 1)$. Other cirque lakes in the CS ecoregion are Badger Lake southeast of Mount Hood and Wahtum Lake southwest of Hood River.

Volcanism has also played a major role in the creation of lake basins in the CS ecoregion. Nine of the 44 High Cascades lakes in the ecoregion have been impounded by lava flows which have interrupted drainage systems. In many cases, these flows have occurred in glaciated terrain, e.g. glacial valleys, to form and often to enlarge lakes. The basin containing Diamond Lake, in the Umpqua National Forest, was a former broad, glacial valley which was subsequently blocked about one-million years ago by lava flows issuing from the flanks of Mount Thielsen, three miles away. The form of the lake reflects these events; elliptical in outline, a mean depth of 24.0 feet $(7.3 \mathrm{~m})$, and one end shallower than the other. The lakes in the selected data base which have similar origins are Todd Lake, Summit Lake, Fourmile Lake, and Lost Lake in the Hood River basin. 
The selected lake-watershed ecosystems of the CS ecoregion are diverse in their morphological and chemical make-up. The average elevation for these systems is 4884 feet $(1489 \mathrm{~m})$, with an average annual precipitation of 67 inches $(1702 \mathrm{~mm})$. The average lake area is $1.38 \mathrm{mi}^{2}\left(3.6 \mathrm{~km}^{2}\right)$, the average watershed area and $\mathrm{DBr}$ is $11.0 \mathrm{mi}^{2}(28.6$ $\mathrm{km}^{2}$ ) and 34.2, respectively. Because of the higher precipitation amounts that the watersheds collect, the mean TRt is relatively low at 5.3 years. These are quite deep and clear lakes; the average mean depth is 34.7 feet $(10.5 \mathrm{~m})$, and a secchi disk depth averaging 28.6 feet $(8.7$ m). Their watersheds are mainly used as forest lands (averaging 83.9\%), with the primary water use being recreation and water supply.

In almost all respects, Crater Lake is a unique lake-watershed ecosystem. Certainly, there is no other in the collection of selected lakes that is as clear ( $\mathrm{SD}=95.1$ feet or $28.9 \mathrm{~m}$ ), that has a lower $\mathrm{DBr}$ (0.32), or that has a longer TRt (156.5 years). Crater Lake is also the deepest lake in the United States and the seventh deepest lake in the world with a maximum depth of 1932.0 feet $(588.9 \mathrm{~m})$.

Eastern Cascades Slopes and Foothills Ecoregion

The Eastern Cascades Slopes and Foothills (ECSF) ecoregion constitutes a transitional environment between the more humid, rugged Cascades ecoregion to the west and the drier Columbia Basin, Blue Mountains, and Snake River Basin/High Desert ecoregions to the east. The entire, roughly triangular, ecoregion stretches from the columbia River in the north, where it is as narrow as 20 miles $(32 \mathrm{~km})$ in width, south to the California border, where it adjoins a northeastern lobe of the Sierra Nevada ecoregion. Here, the ECSF ecoregion extends much 
further east; a distance of approximately 100 miles $(161 \mathrm{~km})$. Elevation varies from near sea level at the Columbia River, to over 7000 feet $(2133 \mathrm{~m})$, with local relief commonly between 500 and 2500 feet (152-762 m). The geologic substrate is relatively young, with lava flows occurring as recent as 1000 to 6000 years b.p.; volcanic cones dot the landscape in certain locales. A thick mantle of volcanic pumice and ash covers much of the ecoregion, the presence of which greatly influences the soil characteristics and the rainfall runoff relationships in the region. There is a pronounced rain shadow in the lee of the Cascade Range on the western margins of the ecoregion where average annual precipitation receipts decrease from about 60.0 inches $(1524 \mathrm{~mm})$ to 15.0 inches $(381 \mathrm{~mm})$ in the north, and from 50.0 inches $(1270 \mathrm{~mm})$ to 20.0 inches $(508 \mathrm{~mm})$ in the south. Although rangeland is an important major land use, forested lands dominate as the primary land use, with Ponderosa pine (Pinus ponderosa) being the principle commercial tree species.

Ten of the 98 lake-watershed ecosystems selected for study are found in the ECSF ecoregion. These include lakes as small as $0.16 \mathrm{mi}^{2}$ $\left(0.41 \mathrm{~km}^{2}\right)$ for South Twin Lake and $0.18 \mathrm{mi}^{2}\left(0.47 \mathrm{~km}^{2}\right)$ for North Twin Lake, to the largest lake in Oregon in terms of surface area -- Upper Klamath Lake with $96.16 \mathrm{mi}^{2}\left(249 \mathrm{~km}^{2}\right)$ of water. All of the lakes found in the ECSF ecoregion are of volcanic or tectonic origin. Little Lava Lake and nearby Lava Lake are basins in depressions among a series of lava flows which issued from Mt. Bachelor and Broken Top. These lava flows altered the drainage of the area, thereby creating the two lakes. Both lakes are slightly over 4700 feet $(1433 \mathrm{~m})$ elevation and both 
receive about 45 inches of precipitation annually $(1143 \mathrm{~mm})$. There are no permanent surface streams which contribute to Lava Lake, and on Ty in very high-water periods does Little Lava Lake receive inflow. There is a significant difference, however, between the hydrology of these two systems. Lava Lake, has a smaller watershed area, $17.78 \mathrm{mi}^{2}\left(19.2 \mathrm{~km}^{2}\right)$, a larger volume (1100 ac ft), a much larger $\mathrm{DBr}$ of 82.3 , and a shorter TRt of 0.20 years $(2.4$ months). These hydrologic and morphometric properties also paralllel a difference in total-phosphorus and chlorophyl1-a concentrations -- in both cases higher in Lava Lake. Despite these concentrations, Johnson, et al. (1985) have classified Lava Lake as oligotrophic, bordering on mesotrophy, while Little Lava is assigned a mesotrophic status. This is supported by the MEI values generated in this study.

North Twin and South Twin Lakes are unique in terms of their origin among the selected lake-watershed ecosystems. They are both maars, i.e. depressions created when rising magma in the earth's crust contacted with subsurface water. Both are nearly circular and have very small watershed areas (and, therefore, drainage ratios), characteristic of lakes of this type. They are deep lakes for their size, with a maximum depth of 58.0 feet $(17.7 \mathrm{~m})$ for South Twin, 63.0 feet $(19.2 \mathrm{~m})$ for North Twin Lake, and mean depths of 33.0 feet $(10.0 \mathrm{~m})$ and 40.0 feet $(12.2 \mathrm{~m})$, respectively. There is no surface inflow or outflow from either lake; water is lost and gained through subsurface seepage and by evaporation.

At an elevation of 7985 feet $(2434 \mathrm{~m})$, Paulina Peak, a shield volcano, rises from the basalt layered plateau east of La Pine. This 
peak is the highest point surrounding Newberry Crater, within which Paulina and East Lakes are located. These are caldera lakes formed when the crater collapsed approximately 20,000-25,000 years ago. Subsequent accumulations of glacial ice during the closing phases of the Pleistocene epoch carved a single outlet from the caldera, and as recent as 2050 years b.p. volcanic eruptions and lava flows separated the two lakes present today. Paulina Lake is the larger of the two with a surface area of $2.4 \mathrm{mi}^{2}\left(6.19 \mathrm{~km}^{2}\right)$. Mean depth is also greater in Paulina Lake, 163.0 feet $(49.7 \mathrm{~m})$, than for East Lake at 67.0 feet $(20.4$ m) . Theoretical retention times differ significantly for the Lakes, mainly because of the large difference in volumes -- East Lake has a volume of $69,600 \mathrm{ac} \mathrm{ft}$ and a TRt of 18 years; Paulina Lake with a volume of $249,800 \mathrm{ac} \mathrm{ft}$ and a TRt of 26 years. These differences in lake morphometry and hydrology are reflected in both lakes' water chemistry; total-phosphorus and chlorophyll-a concentrations for East Lake are substantially lower, and MEI values indicate higher potential productivity for Paulina Lake (MEI $=2.06)$ than for East Lake (MEI = 1.55). Although human activities, especially recreation, can be intense at times during the snow-free months, the water quality of these large caldera lakes stem from natural conditions.

The boundary separating the ECSF ecoregion from the Cascades ecoregion has been determined such that it bisects the westernmost portions of the watersheds of Davis, Agency, and Upper Klamath Lakes. The location of the ecoregion boundary in these areas is not sharply defined. Rather, the boundary represents a transition, primarily in natural vegetation, soils, and land surface-form, from the leeward 
east-facing slopes of the Cascade Mountains to the drier vegetation communities, volcanic ash and pumice covered, plateau-like topography characterizing the ECSF ecoregion. Most of the primary surface drainage networks contributing to these three lakes, as well as a great proportion of their watershed areas, are within the ECSF ecoregion.

Davis Lake was formed by the impoundment of 0de11 Creek by a lava flow which post-dates the eruption of Mount Mazama (Phillips 1968). The basin containing Upper Klamath and Agency Lakes is a graben. Despite their differing origins, these three systems are similar in many ways. They are shallow lakes for their size. Davis Lake has an average maximum depth of 20.0 feet $(6.1 \mathrm{~m})$, a mean depth of 9.0 feet $(2.7 \mathrm{~m})$, and a lake area of $6.1 \mathrm{mi}^{2}\left(15.8 \mathrm{~km}^{2}\right)$. Agency and Upper Klamath Lakes have maximum depths 7.0 feet $(2.1 \mathrm{~m})$ and 50.0 feet $(15.2 \mathrm{~m})$, mean depths of 3.0 feet $(0.91 \mathrm{~m})$ and 13.8 feet $(4.2 \mathrm{~m})$, and lake surface areas of $14.5 \mathrm{mi}^{2}\left(37.6 \mathrm{~km}^{2}\right)$ and $96.1 \mathrm{mi}^{2}\left(249 \mathrm{~km}^{2}\right)$, respectively. Though these three lakes have watersheds among the largest in Oregon, their drainage ratios are only moderate. All three are naturally productive biologically, with medium to high concentrations of total-phosphorus. Because of their low mean depths, nutrien-rich sediments are easily disturbed by wind-generated currents, causing a resuspension of nutrients, and, therefore, an increased biological avilability. Johnson, et a1. (1985) support these points in their trophic state assignments, reporting Davis Lake as mesotrophic. Agency and K1amath Lakes are hyper-eutrophic systems, probably due to the naturally high nutrient concentrations in the thick deposits of Mazama ash and extensive marsh areas on their watersheds. 
The selected lake-watershed ecosystems which are located in the ECSF ecoregion, taken collectively, are diverse in their morphometric and hydrologic character. This is due, in great part, to their types of origin. There seems to be a general inverse relationship between watershed area and theoretical retention times, and a strongly positive correspondence between watershed area and average annual sediment yield. With an average morphoedaphic index of 2.0 (Agency Lake notwithstanding at MEI $=17.0)$, mesotrophic conditions prevail for these lake systems.

Snake River Basin/High Desert Ecoregion

The Snake River Basin/High Desert (SRB/HD) ecoregion is the largest in the state with $29,928 \mathrm{mi}^{2}\left(77,513 \mathrm{~km}^{2}\right)$, and consists of the basin and range topography and the moderate to severely dissected lava plains and plateaus of central-southern, southeastern, and east-southeastern 0regon. As the name implies, this is an area of low moisture; average annual precipitation varies from less than 10.0 inches $(254 \mathrm{~mm})$ up to 25.0 inches $(635 \mathrm{~mm})$, but only in the highest elevations. Local relief is low for large areas of the ecoregion, although some stream valleys have incised up to 3000 feet $(914.4 \mathrm{~m})$ through the regional basaltic strata. Maximum local relief is attained in the basin and range topography, with elevational differences up to 1500 feet $(457.2 \mathrm{~m})$ over short distances associated with fault scarps. The northern boundary of the ecoregion (in Oregon) ends at the foot of the central mountains complex, where land surface-form changes abruptly. The primary factor controlling the location of the western boundary is the change from the ash- and pumice-dominated substrate and forest lands of the ECSF ecoregion to the shrub-steppe and Western Juniper (Juniperus 
occidentalis) zones of the SRB/HD ecoregion. Rangeland is the primary land use in the ecoregion; minor areas of land are irrigated for hay-crops and pasture.

Water is at a premium in this arid ecoregion, yet some of Oregon's largest lakes, by surface area, are found here: lakes such as Abert Lake, $57.1 \mathrm{mi}^{2}\left(147.9 \mathrm{~km}^{2}\right)$, Summer Lake, $39.1 \mathrm{mi}^{2}\left(101.3 \mathrm{~km}^{2}\right)$, and Crump Lake with $12.0 \mathrm{mi}^{2}\left(31.1 \mathrm{~km}^{2}\right)$ of surface area. Harney Lake, Upper Cow, Fish, and Mann Lakes are other natural systems selected which are largely encompassed by the ecoregion. Included also is eutrophic Chickahominy Reservoir, situated at the base of the Sage Hen Hills, and with in the Harney Lake watershed.

According to the trophic state determinations made by Johnson et al. (1985) for the selected lakes, eutrophic conditions prevail throughout the ecoregion, with the exception being Fish Lake high on Steens Mountain. Fish Lake is a small cirque lake at an elevation of 7371 feet $(2247 \mathrm{~m})$ impounded by a glacial moraine of Pleistocene age. The watershed is a classic, "U"-shaped glacial valley rising to a maximum elevation of 7558 feet $(2304 \mathrm{~m})$ in a distance of about one mile $(1.6 \mathrm{~km})$. Although it is the smallest lake among those selected which occur in the ecoregion, $0.025 \mathrm{mi}^{2}\left(0.06 \mathrm{~km}^{2}\right)$, Fish Lake is the deepest with a maximum depth of 30.0 feet $(9.1 \mathrm{~m})$ and a mean depth of 15.0 feet $(4.6 \mathrm{~m})$. The watershed of the lake is covered with Quaking Aspen (Populus tremuloides) accounting for the 87 percent forest land use value. It is the only lake-watershed ecosystem in the SRB/HD ecoregion which is dominated by forest land use, and that has a mesotrophic status. 
Mann Lake, at 4150 feet $(1265 \mathrm{~m})$ elevation in the Alvord Valley, is a small, shallow, and saline remnant of a northern extension of Pleistocene Lake Lahontan. Lake area is $0.43 \mathrm{mi}^{2}\left(1.1 \mathrm{~km}^{2}\right)$, mean depth is 6.0 feet $(1.8 \mathrm{~m})$, and the interior-draining watershed, which is 93 percent rangeland, is $28.0 \mathrm{mi}^{2}\left(72.5 \mathrm{~km}^{2}\right)$ in area. Upper Cow Lake is of different origin, having been dammed by lava flows in the Jordan Craters area of eastern MaTheur County. This hyper-eutrophic lake, like Mann Lake, receives very low amounts of annual runoff --1.7 inches $(4.32 \mathrm{~cm}$ ) in an average year from its arid, rangeland, $208.5 \mathrm{mi}^{2}\left(540 \mathrm{~km}^{2}\right)$ watershed. Despite low runoff, the Upper Cow Lake system has a drainage ratio of 141.2 , which, coupled with a low mean lake depth of 7.1 feet $(2.2 \mathrm{~m})$, results in a short theoretical retention time of 0.4 years $(4.8$ months). Total-phosphorus is very high $(0.204 \mathrm{mg} / 1)$ and the water transparency is also low, with a secchi disk depth of 0.71 feet $(0.21$ m).

Abert Lake, Summer, and Crump Lakes are lakes resulting from the collection of Pleistocene glacial meltwaters in depressions caused by large scale faulting in the basin and range physiographic province. They are remnants of once large pluvial lakes that covered much of the ecoregion at a time when precipitation was high and evaporation less. A generalized soils map shows large areas of these old lacustrine sediments adjacent to the lakes. The three lakes are in closed, interior-draining watersheds, and act as evaporation "sumps" -characteristics which makes them the most saline lake-watershed ecosystems in the state.

Harney Lake has the largest watershed of any lake in Oregon, with 
about $5084 \mathrm{mi}^{2}\left(13,168 \mathrm{~km}^{2}\right)$, and, technically, is a closed-bas in lake occupying the lowest point in the Malheur/Harney Lake basin (Johnson, et al. 1985). The level of Harney Lake fluctuates widely; completely dry in most of historic time, in contrast to a current surface area of 224.8 $m i^{2}\left(582.3 \mathrm{~km}^{2}\right)$, a water level which has merged in recent years with that of Mud Lake and Malheur Lake (Witt Anderson, personal communication). Such fluctuations in surface area makes the definition of the Harney Lake system very difficult, especially the lake morphometric measures.

\section{Blue Mountains Ecoregion}

The BTue Mountains (BM) ecoregion is the second largest ecoregion in 0regon. The $22,487 \mathrm{mi}^{2}\left(58,241 \mathrm{~km}^{2}\right)$ area encompasses a complex of mountain ranges including the Wallowa, Ochoco, and Blue Mountains, as well as the Strawberry, Greenhorn, and Elkhorn Ranges. Relief is highly variable within the BM ecoregion. Moderate slopes are common in the 0choco and Blue Mountains, while the heavily glaciated Wallowa Mountains exhibit the greatest relief. Valley elevations are about 2400 feet (731 $m$ ) in areas of the western 0choco Mountains and approximately 2900 feet $(884 \mathrm{~m})$ in the broad lowland areas near the city of La Grande between the Blue and Wallowa Mountains. Maximum elevations range from about 6800 feet $2072 \mathrm{~m}$ ) in the Elkhorn and Ochoco Mountains, 8900 feet (2713 $\mathrm{m})$ in the Blue Mountains, and up to 9600 feet $(2926 \mathrm{~m})$ in the Wallowas.

Thirteen of the 98 selected lake-watershed ecosystems are found in the BM ecoregion; most are located in the glaciated uplands of the eastern areas of the Blue Mountains and in the Wallowa Mountains. Other lakes which were included in this study exist in the ochoco and 
Strawberry Mountains. For example, Delintment Lake (Figure 11) 1ies in a small $1.1 \mathrm{mi}^{2}\left(2.85 \mathrm{~km}^{2}\right)$ watershed covered by an open pine forest plateau 25 miles $(40.2 \mathrm{~km})$ north of the town of Riley. The elevation of the lake is 5562 feet $(1695 \mathrm{~m})$ in an area of rolling, low-relief uplands that receive about 25 inches $(635 \mathrm{~mm})$ of precipitation per year. Moisture demands are high; annually, only about 10 inches $(254 \mathrm{~mm})$ of runoff is contributed to the lake. This is a small, shallow, eutrophic lake with a surface area of $0.097 \mathrm{mi}^{2}\left(0.25 \mathrm{~km}^{2}\right)$, a mean depth of 8.0 feet $(2.4 \mathrm{~m})$, having the highest total-phosphorus $(0.082 \mathrm{mg} / 1)$ and MEI (5.5) values of any of the selected lakes found in the ecoregion.

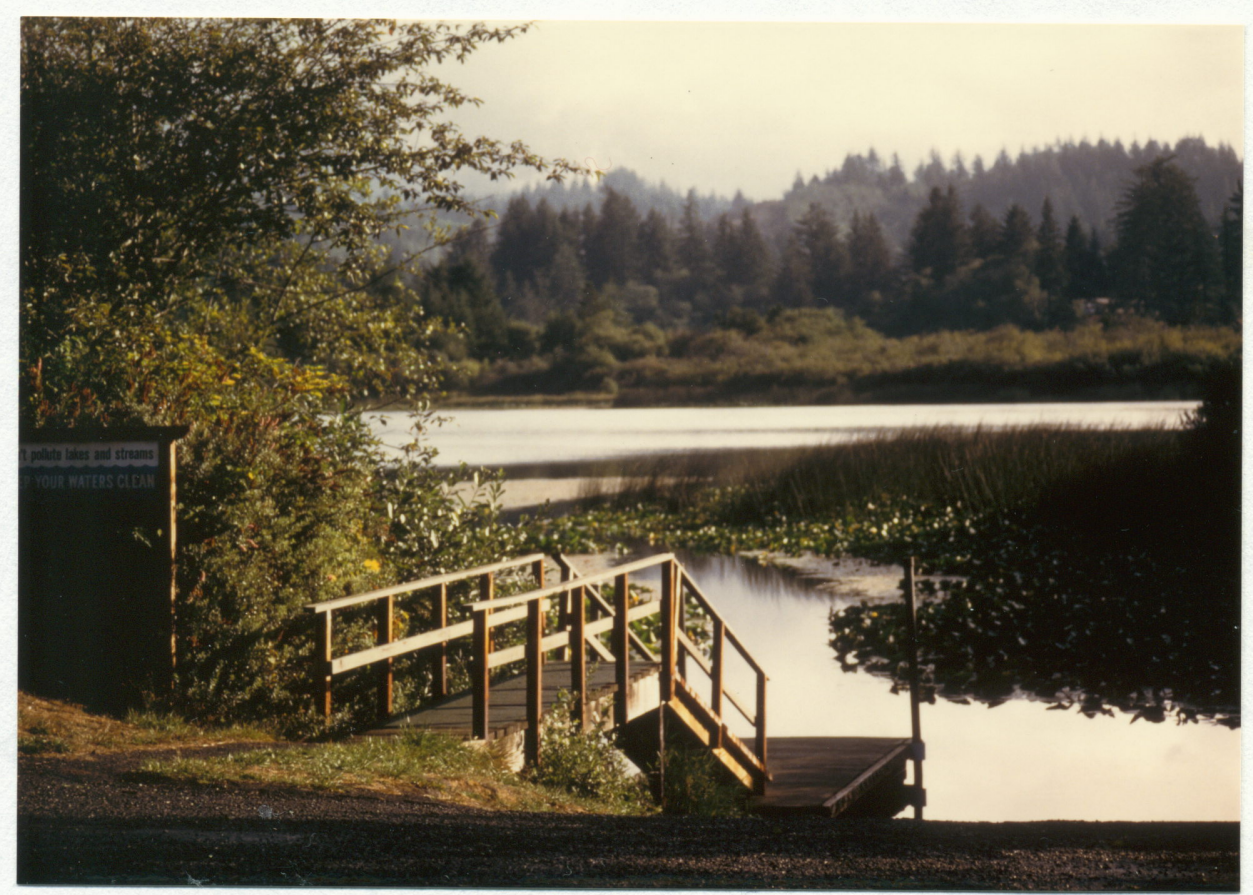

Figure 11. Eutrophic Delintment Lake

Magone Lake is a small natural lake in the Malheur National Forest north-northeast of John Day. At an elevation of 5000 feet $(1524 \mathrm{~m})$, the 
lake is probably of glacial origin; it is situated in a single elongate north-south oriented watershed of $1.35 \mathrm{mi}^{2}\left(3.49 \mathrm{~km}^{2}\right)$. With a surface area of only $0.047 \mathrm{mi}^{2}\left(0.12 \mathrm{~km}^{2}\right)$, it is a deep lake having a mean depth of 29.0 feet $(8.8 \mathrm{~m})$ and a maximum depth of 98.0 feet $(29.8 \mathrm{~m})$. A single intermittent inflow stream feeds the lake, and the watershed collects only 3.5 inches $(8.9 \mathrm{~cm})$ of runoff annually. The combination of these morphometric and runoff attributes result in a relatively long TRt of 5.8 years and a low sediment yield of 135 tons per year.

Some of the most spectacular alpine glacial lakes are found in the Wallowa Mountains. The lakes included in the data base found here are Mirror Lake (Figure 12), Minam, and Glacier Lakes. All three are well over 7000 feet $(2133 \mathrm{~m})$ elevation, with Glacier Lake the highest of the 98 selected lakes at 8200 feet $(2499 \mathrm{~m})$.

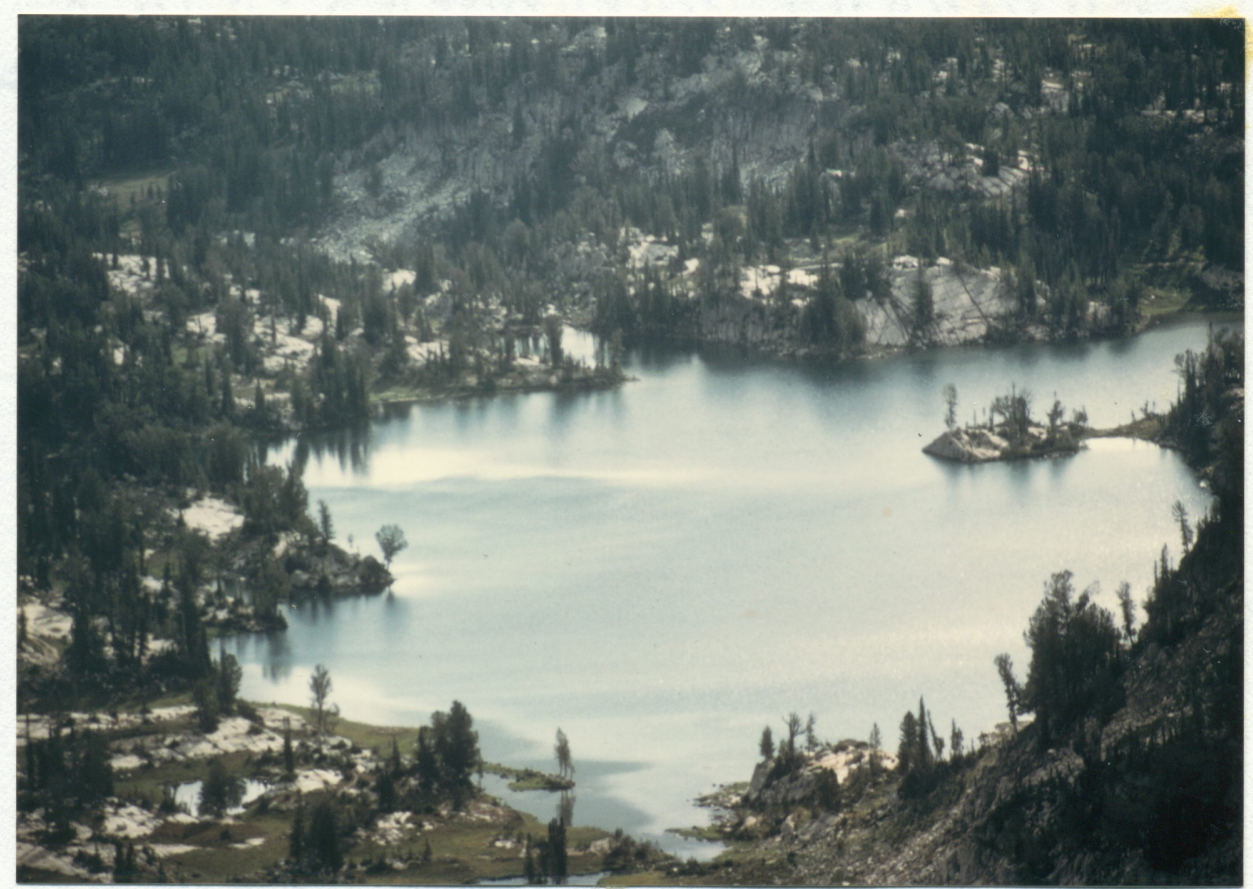

Figure 12. 01 igotrophic Mirror Lake in the Wallowa Mountains. 
Characteristic of most remote alpine lakes, these lakes are very oligotrophic with secchi disk depths averaging 31.3 feet $(9.5 \mathrm{~m})$, very low chlorophyll-a and total-phosphorus concentrations, and small watersheds not larger than $0.76 \mathrm{mi}^{2}\left(2.0 \mathrm{~km}^{2}\right)$. MEI values also suggest an extremely low trophic regime; values range from 0.02 for the Glacier Lake system to 0.20 for Minam Lake. Al1 three of these lake-watershed ecosystems are in the timberline zone of the Wallowa Mountains, dominated by a substrate of granodiorite, with thin soil mantles mainly derived from volcanic ash and loess.

Wallowa Lake is one of the best examples of a large glacial moraine lake in the United States (Figure 13). The watershed, $48.7 \mathrm{mi}^{2}$ $\left(126 \mathrm{~km}^{2}\right)$, includes the catchment areas of Minam, Mirror, and Glacier Lakes further south at higher elevations (Figure 14). Wallowa Lake is the largest natural lake in the BM ecoregion; lake area is $2.4 \mathrm{mi}^{2}(6.1$ $\mathrm{km}^{2}$ ). It is also the fourth deepest natural lake in the state at 299.0 feet $(91.1 \mathrm{~m})$, having very narrow littoral areas as indicated by the mean depth of 161.0 feet $(49.1 \mathrm{~m})$. Water is regulated to some degree by a low dam at the outlet, giving the lake a volume greater than 240,000 ac $\mathrm{ft}$. Because of the thin, young soils and relatively impermeable bedrock throughout much of the watershed, runoff to the lake constitutes a large fraction of the average annual precipitation balance, resulting in a TRt of 2.5 years -- quite a low figure for a lake with such a large volume.

In summary, the lake watershed ecosystems of the BM ecoregion have generally high water quality. Except for Wallowa Lake, they are small lakes in small watersheds at high elevations of moderate-to-rugged 
terrain. Although they differ in origin, these are deep lakes, averaging 30.0 feet $(9.1 \mathrm{~m})$. The major land use in these watersheds is forest land, with open alpine areas being of secondary importance.

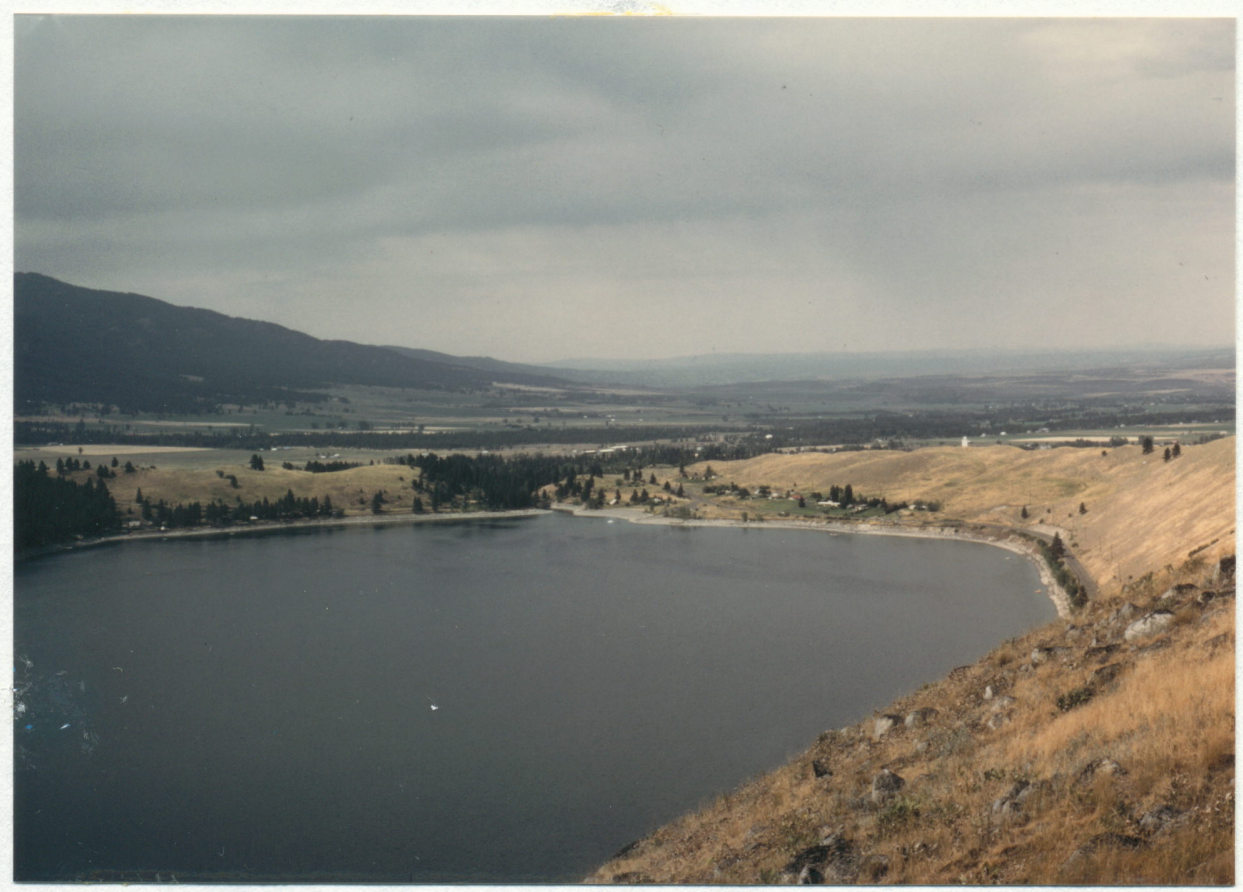

Figure 13. Glacial moraines impound Wallowa Lake.

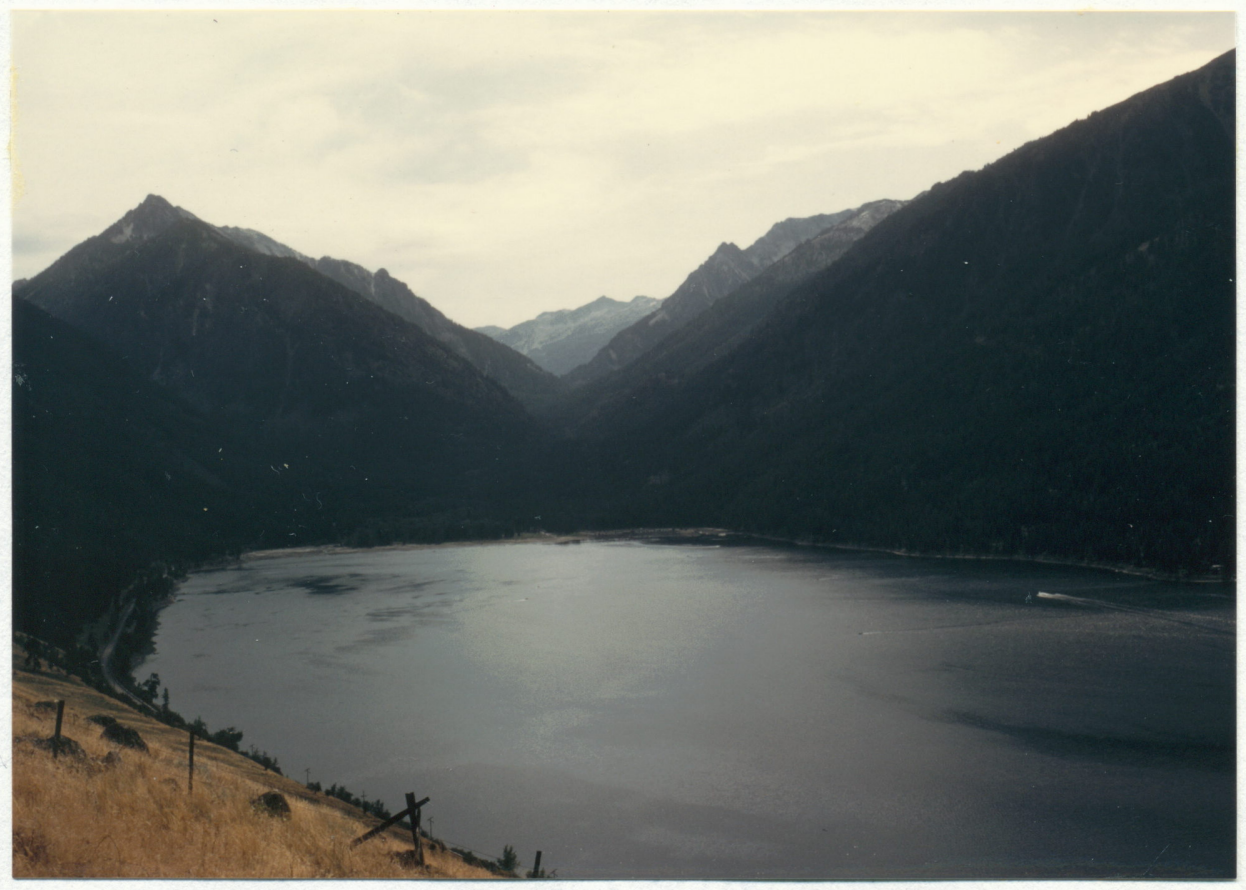

Figure 14. Wallowa Lake's watershed is steep and dissected. 


\section{CHAPTER V}

\section{DATA ANALYSIS}

The multivariate statistical techniques of principal components factor analysis and cluster analys is were applied to the data matrix for identification of typical lake-watershed ecosystems in oregon. The primary objective of the two techniques is to simplify and organize large amounts of data.

Factor analysis is a statistical method that is useful for identifying structure or patterns among many data which are obtained for a number of individual units or areas. Use of the technique has led to a major research thrust in geography that has focused on the manipulation of multivariate data for areal classification and the identification of regional systems (cf. Cole and King 1968; Mather and Doornkamp 1970; Smith 1975; and Taylor 1977). In geographical examples, the data, or variables, are properties of the individual units or areas that make up the total problem involved in the analysis. Factor analys is is basically a data reduction method in which common sources of variance are sought amongst the variables. Thus, factor analys is attempts to quantitatively identify the characteristics or "factors" which the variables have in common, to el iminate redundant variables, and to determine the nature and order of importance of the factors derived from the data (Mather and Doornkamp 1970, p. 163).

Factor analysis is a two stage procedure -- an input stage and an 
output stage -- involving five data matrices (Figure 15). A data matrix consisting of the 24 variables measured over the 98 selected lake-watershed ecosystems was first constructed (Appendix A). The data matrix was generated in a computer spreadsheet program for storage and formatting purposes. Missing data were specially encoded to complete the matrix. Relationships among variables (across various combinations of lake systems) were initially explored using bivariate scatterplots and least-squares linear regression to evaluate the statistical strengths of the relationships and to guide variable selection. Scales of measurement were not uniform for all variables, and they were not, in each case, normally distributed. The final data matrix for use in the factor analysis program was standardized by either square-root and logarithmic transformation functions.
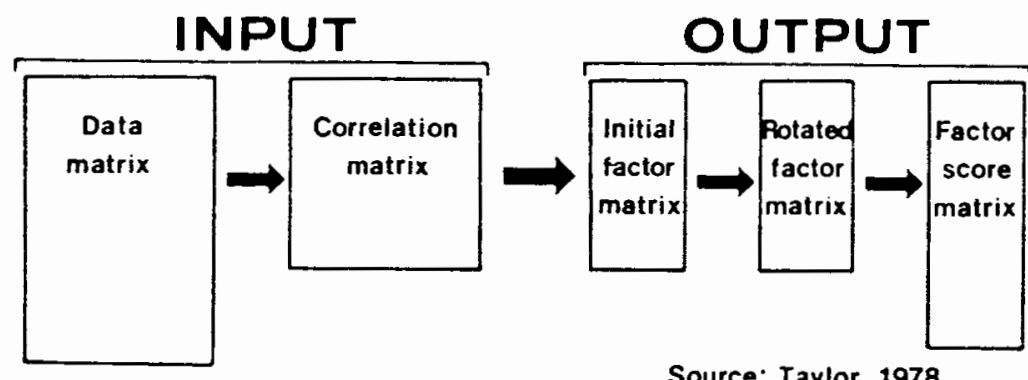

Source: Taylor, 1978

Figure 15. The factor analys is procedure.

The second phase of the input stage was the generation of a correlation matrix using "SIGSTAT", a microcomputer-based version of the Biomedical Computer Program (BMD) statistical software system (SIGSTAT 1979). Harney Lake was deleted in the pairwise deletion from further consideration because of an excessive amount of missing data values. The remaining 97 lake-watershed ecosystems were then used in the factor 
analysis.

The matrices of interest in the output stage are the rotated factor loading matrix and the factor score matrix. The rotated factor loading matrix represents the reduction of the 24 variables to 5 common factors and their numerical relationships to the original variables (Table VI). The loading values indicate the structure of the five factors which have been extracted. These factors describe groups of interrelated variables as discussed further in this chapter, and they account for 71.1 percent of the total variance.

TABLE VI

ROTATED FACTOR LOADING MATRIX SORTED BI FACTOR

\begin{tabular}{|c|c|c|c|c|c|c|c|c|c|}
\hline Yariable & $\begin{array}{c}\text { FACTOR } \\
\text { I }\end{array}$ & $\operatorname{Tar} 1 \mathrm{~b}^{\circ}$ & $\begin{array}{c}\text { PACTOR } \\
\text { II }\end{array}$ & Var1able & $\begin{array}{l}\text { FACIOR } \\
\text { III }\end{array}$ & tariable & $\begin{array}{c}\text { PACTOR } \\
\text { IV }\end{array}$ & Tarlablo & $\begin{array}{c}\text { PICTOR } \\
V\end{array}$ \\
\hline 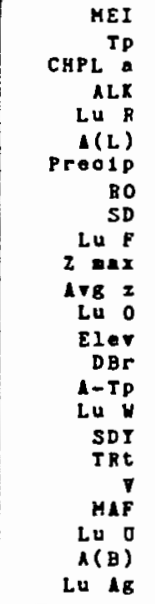 & $\begin{array}{r}.819 \\
.775 \\
.729 \\
.727 \\
.617 \\
.426 \\
-.576 \\
-.565 \\
-.546 \\
-.492 \\
-.268 \\
. .198 \\
-.111 \\
-.094 \\
-.065 \\
.031 \\
.082 \\
.095 \\
.101 \\
.108 \\
.154 \\
.212 \\
.307 \\
.340\end{array}$ & 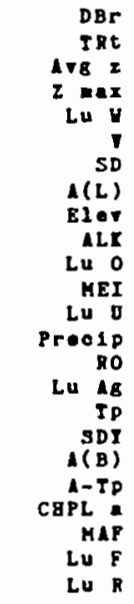 & $\begin{array}{r}.609 \\
-.926 \\
-.883 \\
-.873 \\
-.848 \\
-.700 \\
-.614 \\
-.272 \\
-.124 \\
-.082 \\
-.059 \\
-.014 \\
-.006 \\
.025 \\
.029 \\
.080 \\
.084 \\
.092 \\
.108 \\
.1110 \\
.111 \\
.119 \\
.182 \\
.244\end{array}$ & 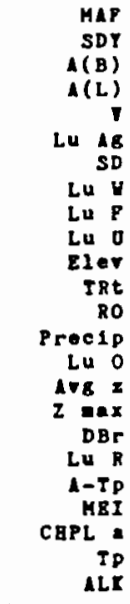 & $\begin{array}{r}.909 \\
.901 \\
.882 \\
.835 \\
.579 \\
.443 \\
-.238 \\
-.158 \\
-.099 \\
-.087 \\
-.062 \\
-.054 \\
-.052 \\
-.027 \\
-.013 \\
.046 \\
.050 \\
.160 \\
.167 \\
.169 \\
.182 \\
.212 \\
.240 \\
.245\end{array}$ & 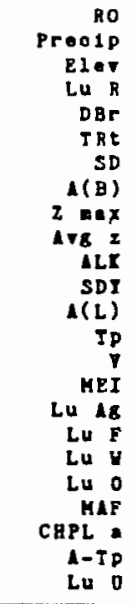 & $\begin{array}{r}.725 \\
.689 \\
-.777 \\
-.346 \\
-.341 \\
-.231 \\
-.198 \\
-.176 \\
-.1332 \\
-.106 \\
-.092 \\
-.091 \\
-.067 \\
-.003 \\
.020 \\
.035 \\
.045 \\
.079 \\
.080 \\
.087 \\
.122 \\
.123 \\
.160 \\
.326\end{array}$ & 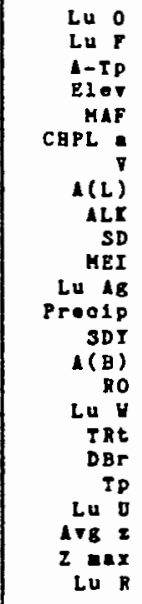 & $\begin{array}{r}.877 \\
-.798 \\
-.221 \\
-.164 \\
-.130 \\
-.105 \\
-.010 \\
-.005 \\
-.004 \\
.005 \\
.009 \\
.012 \\
.023 \\
.033 \\
.043 \\
.043 \\
.070 \\
.080 \\
.081 \\
.099 \\
.118 \\
.145 \\
.145 \\
.272\end{array}$ \\
\hline $\begin{array}{l}\text { FACTOR } \\
\text { QIGENTALUE } \\
\text { PERCENTACE } \\
\text { OF TOTAL } \\
\text { VARIAYCE } \\
\text { COMOLATIYE } \\
\text { PERCEYTAGE } \\
\text { OP TOTAL } \\
\text { TARIAACE }\end{array}$ & $\begin{array}{l}6.536 \\
27.20\end{array}$ & & $\begin{array}{l}4.734 \\
19.70\end{array}$ & & $\begin{array}{r}2.592 \\
10.80 \\
57.8\end{array}$ & & $\begin{array}{l}1.756 \\
7.30 \\
65.1\end{array}$ & & $\begin{array}{r}1.454 \\
6.10 \\
71.1\end{array}$ \\
\hline
\end{tabular}

- Table generatod on "sopercalc-3" apreadshet progren

The factor score matrix (Table VII) gives values for new 
variables, the five factors, for each of the 97 lake-watershed ecosystems. The factor score values are derived from a formula that defines factors as a function of the original variables, weighted by their respective loadings from the rotated factor loading matrix.

\section{INTERPRETATION OF THE FACTOR ANALYSIS RESULTS}

Because the five factors are indicators of the interrelationships between several variables, the interpretation of each factor is essentially a subjective labeling procedure. Factors are labeled by trying to find a name or expression that clearly denotes the pattern of variable loadings given in the rotated factor loading matrix. High loadings on a factor, both positive and negative, guide the labeling process. Loadings of near zero are also of use in interpretation because they indicate the variables that a factor does not represent. Factor $I$ is a nutrient loading dimension. The factor describes high nutrient concentrations associated (positively) with medium-to-large, turbid lakes in drier rangeland watersheds receiving low amounts of precipitation and runoff. The pattern of loadings on Factor I suggest that the lakes with lower hydraulic contributions also tend to have higher nutrient concentrations and, therefore, a decreased transparency. The highest positive loadings are on MEI (0.819), Tp, CHLPL-a, and ALK with loadings of $0.775,0.729$, and 0.727 , respectively. The Lu(R) variable loads relatively high $(0.617)$, while $A(L)$ is not as strongly represented $(0.426)$. Factor I is moderately, but negatively associated with PRECIP $(-0.576)$, RO $(-0.565)$, and SD depth $(-0.546)$. 
TABLE VII

FACTOR SCORE MATRIX SORTED BY FACTOR

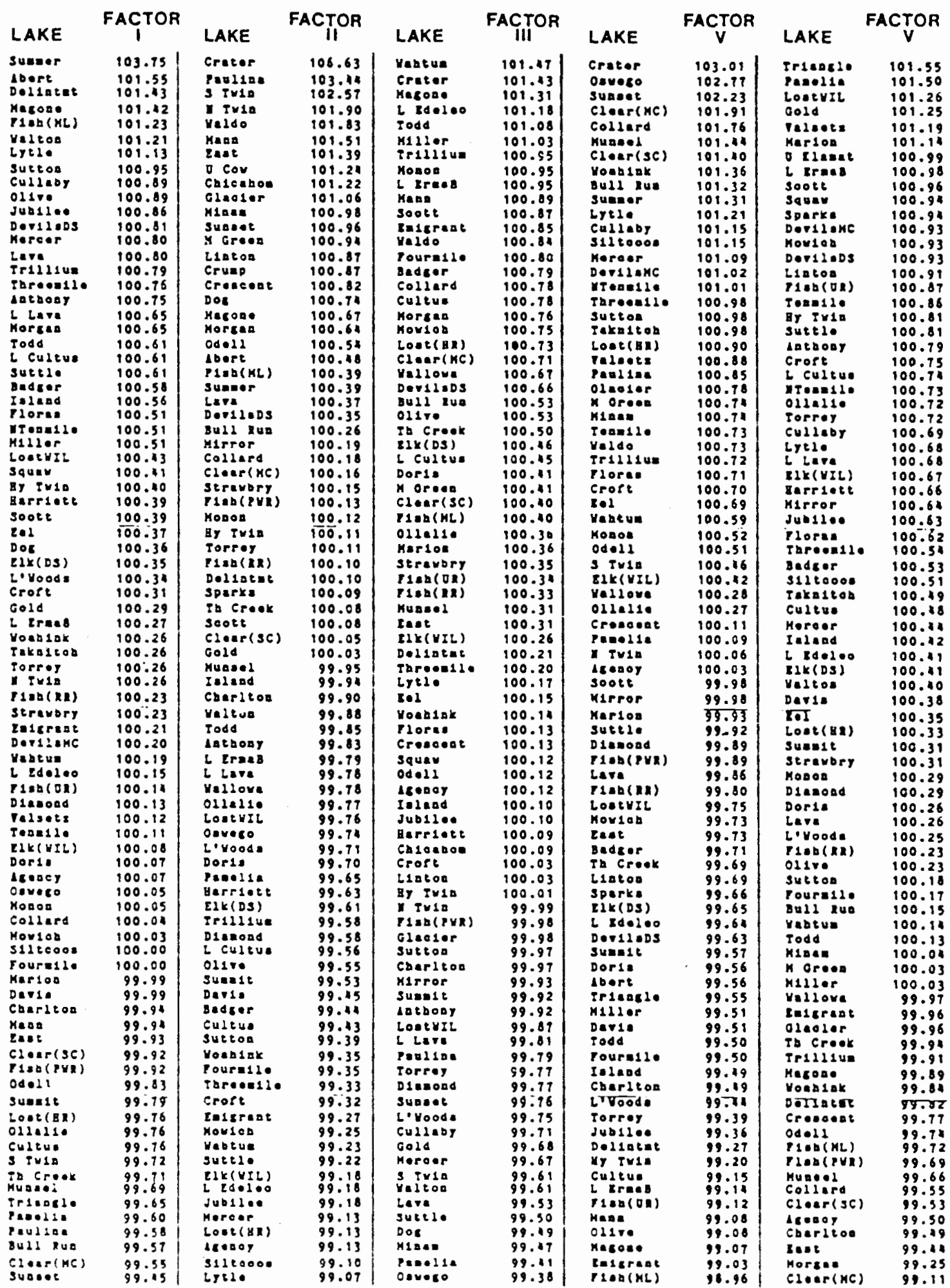


TABLE VII [Continued]

FACTOR SCORE MATRIX SORTED BY FACTOR

\begin{tabular}{|c|c|c|c|c|c|c|c|c|c|}
\hline LAKE & FACTOR & LAKE & FACTOR & LAKE & FACTOR & LAKE & FACTOR & LAKE & $\underset{V}{\text { FACTOR }}$ \\
\hline $\begin{array}{l}\text { Crescont } \\
\text { sperks } \\
\text { colenoon }\end{array}$ & $\begin{array}{l}99.39 \\
99.31 \\
99.17\end{array}$ & $\begin{array}{l}\text { Cullaby } \\
\text { Iakajtob } \\
\text { Eel }\end{array}$ & $\begin{array}{l}98.98 \\
98.91 \\
98.89\end{array}$ & 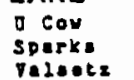 & $\begin{array}{l}99.33 \\
99.09 \\
99.07\end{array}$ & $\begin{array}{l}\text { L Lara } \\
\text { Gold } \\
\text { b Culeus }\end{array}$ & $\begin{array}{l}98.95 \\
98.94 \\
98.85\end{array}$ & $\begin{array}{l}\text { Yeldo } \\
\text { Dor } \\
\text { pauline }\end{array}$ & $\begin{array}{l}98.97 \\
98.78 \\
98.66\end{array}$ \\
\hline $\begin{array}{l}\text { Cruap } \\
\text { c. Con }\end{array}$ & $\begin{array}{l}99.11 \\
99.08 \\
98.97\end{array}$ & 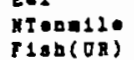 & $\begin{array}{l}96.87 \\
90.84\end{array}$ & 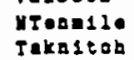 & $\begin{array}{l}98.78 \\
98.73\end{array}$ & $\begin{array}{l}\text { yedton } \\
\text { Morsea }\end{array}$ & $\begin{array}{l}98.75 \\
98.79\end{array}$ & $\begin{array}{l}\text { TY1a } \\
\text { Cruap }\end{array}$ & 98.51 \\
\hline $\begin{array}{l}\text { o. Cov } \\
\text { rejoo }\end{array}$ & 98.83 & Derils & 98.80 & Derie & 98.67 & Dos & 98.78 & DCoy & 97.82 \\
\hline $\begin{array}{l}\text { Mgror } \\
\text { L10tod } \\
\text { D. traset } \\
\text { H. Greer }\end{array}$ & $\begin{array}{l}98.22 \\
98.10 \\
97.40 \\
97.38\end{array}$ & $\begin{array}{l}\text { M1110r } \\
\text { Mer1on } \\
\text { Yalatez } \\
\text { rioras }\end{array}$ & $\begin{array}{l}98.79 \\
98.73 \\
98.64 \\
98.61\end{array}$ & $\begin{array}{l}\text { DerilaHC } \\
\text { Trieogle } \\
\text { Suever } \\
\text { Tenetie }\end{array}$ & $\begin{array}{l}98.50 \\
98.28 \\
98.23 \\
97.89\end{array}$ & $\begin{array}{l}\text { Cruap } \\
\text { Herriett } \\
\text { Straudry } \\
\text { dnthong }\end{array}$ & $\begin{array}{l}98.75 \\
98.62 \\
98.57 \\
98.50\end{array}$ & 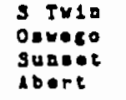 & $\begin{array}{l}97.80 \\
97.79 \\
97.55 \\
97.55\end{array}$ \\
\hline
\end{tabular}

+ table generated on "supercalc - 3" spreadsheet program

The variables loading on Factor I comprise the largest block of interrelated variables and account for 27.2 percent of the total variance.

The lake-watershed ecosystems best described by Factor I are Summer Lake, Abert, Delintment, Magone, Fish Lake in the Steens Mountains, and Walton Lake. The inverse interpretation of factor I describes small-to-medium sized, transparent lakes with low nutrient concentrations in sparsely forested watersheds delivering high amounts of runoff generated from high amounts of precipitation. Examples of lake-watershed systems from this perspective are Crater Lake, Glacier Lake, Minam, Wallowa, and Middle Green Lake. Based on this inverse interpretation and on the original data, Upper Klamath Lake, although loading high, apppears to be inadequately described by factor I.

Factor II is strongly associated (negatively) with morphometric and hydrologic variables; it is a water-retention dimension. Theoretical retention time, mean depth, maximum depth, and land use in water (\% of watershed area) load the highest. Volume and secchi disk depth have moderate loadings. Drainage ratio is inversely related, 
loading positively with a value of 0.609 . The lake-watershed ecosystems Factor II best describes are deep, steep-sided, clear lakes with smal1 watershed areas compared to lake areas and long theoretical retention times. The factor score matrix (Table VII) shows that these are the caldera and maar lakes of the Cascades and Eastern Slopes and Foothills ecoregions. These include Crater Lake, Paulina, East, South Twin, and North Twin Lakes. Also included is Waldo lake -- a glacial moraine lake -- which has all the characteristics described by Factor II. A pronounced outlier to this interpretation is Mann Lake (a factor score of 101.51), which loads sixth highest and is not adequately described. The inverse interpretation of Factor II characterizes Upper Klamath Lake, Triangle Lake, Tenmile, Floras, and Valsetz Lakes, as examples. These are fast-flushing, shallow, turbid lakes with large watersheds compared to lake areas. Factor II explains 19.7 percent of the total variance.

Large lakes in large, hydrologically transmissive watersheds that produce large amounts of sediment are the lake-watershed ecosystems described by Factor III. Although the factor loadings on the variables MAF, SDY, $A(B)$, and $A(L)$ are very high $(>0.83)$, Factor III explains on $1 y$ 10.8 percent of the total variance. However, there are a large number of systems that Factor III seems to characterize well according to the original data. Examples are Upper Klamath Lake, Crump Lake, Abert, Summer, Siltcoos, Tenmile, North Tenmile, Triangle Lake, Devils Lake in the Coast Range ecoregion, Tahkenitch, and Davis Lake.

Factors IV and $V$ explain substantially smaller percentages of the total variance than any of the other Factors -- 7.3 and 6.1 percent, 
respectively. Factor IV loads only moderately high on three variables, positively on average annual precipitation and runoff, and negatively on elevation. Factor IV thus describes low elevation lakes that receive high amounts of precipitation and runoff annually. From the factor score matrix (Table VII), coastal lakes, 0swego Lake, and Bul1 Run Lake are described by Factor IV.

Factor $y$ loads significantly on only two variables, forest land use and the "other" land use category. It is difficult to logically interpret Factor $V$ in terms of the selected lake-watershed ecosystems. Most likely, the factor describes mainly forested lake systems with large riparian or wetland areas in their watersheds. Examples are Triangle Lake, Valsetz, Pamelia, Gold Lake, Marion, Upper Klamath, and Sparks Lake.

The five factors thus generated describe a broad range of lake types, conditions, and processes. As stated above, the primary source of much of the data used as the basis for the generation of the factor scores is the Atlas of Oregon Lakes (Johnson, et al. 1985). The data reported in that document were used to make trophic state assessments on the lakes and reservoirs contained therein. The derived factor scores in this thesis do not show a bias toward lake trophic state conditions or processes mainly because they stem from a simultaneous statistical consideration of all the variables in the thesis data base. In contrast, the trophic state assignments made by Johnson, et al. (1985) are based on the three traditional trophic state indicators -- total phosphorus, chlorophyll-a, and secchi disk -- and, ultimately, were subjective assignments. 


\section{CLUSTER ANALYSIS}

Cluster analysis is a multivariate procedure for grouping individuals or objects into unknown groups, i.e. previously undetected groups. It is specifically a classificatory technique. K-means clustering is a variety of cluster analysis that splits a set of objects into a pre-selected number of groups by maximizing between-group variation relative to within-group variation. The factor score matrix was used as the data input to the $k$-means cluster analysis contained in the "SYSTAT" computer program (Wilkinson 1986). Fifteen groups were initially selected to represent the 97 lake-watershed ecosystems selected. The lake-systems comprising the resultant groups, along with their respective distances from their group's centroid coordinate, are displayed on the following page (Table VIII).

The initial cluster analysis produced two groups, 8 and 9 , as large undifferentiated clusters. A second $K$-Means cluster analys is was performed using the factor scores for each of these two groups (Table IX). Six sub-groups were created for cluster 8 , three sub-groups were selected to represent cluster 9. 
TABLE VIII

$X$-MEANS CLUSTER ANALYSIS RESULTS

GROUP I L-H ECOSYSTEK OIST. FROH CENTROLO GROUP I L-H ECOSYSTEM DIST. FROM CEMTROID

\begin{tabular}{|c|c|c|c|c|c|}
\hline 1 & Squaw & 0.00 & 8 (cont) & $\begin{array}{l}\text { Strawberry } \\
\text { Olive }\end{array}$ & $\begin{array}{l}0.39 \\
0.28\end{array}$ \\
\hline \multirow[t]{2}{*}{2} & Crater & 0.00 & & Jubilee & 0.37 \\
\hline & & & & Morgan & 0.71 \\
\hline \multirow[t]{2}{*}{3} & Upper K1 asath & 0.00 & & & \\
\hline & & & 9 & Threesile & 0.22 \\
\hline \multirow[t]{5}{*}{4} & Dog & 0.63 & & Lytle & 0.11 \\
\hline & Chickahoniny & 0.28 & & Croft & 0.19 \\
\hline & Mann & 0.61 & & Hoanint & 0.42 \\
\hline & Upper Cou & 0.45 & & Cullaby & 0.40 \\
\hline & & & & Mercer & 0.35 \\
\hline \multirow[t]{5}{*}{5} & Middle Green & 0.21 & & Eel & 0.11 \\
\hline & Mina & 0.33 & & floras & 0.27 \\
\hline & Glacier & 0.25 & & Sutton & 0.33 \\
\hline & Mallowa & 0.50 & & Mahtus & 0.58 \\
\hline & & & & Trillius & 0.47 \\
\hline \multirow[t]{2}{*}{6} & Cruap & 0.00 & & Elk (MIL) & 0.22 \\
\hline & & & & Lost (HR) & 0.39 \\
\hline \multirow{2}{*}{7} & Sunser & 0.00 & & Ollalie & 0.46 \\
\hline & & & & Marion & 0.54 \\
\hline \multirow[t]{36}{*}{8} & Enigrant & 0.41 & & Suttle & 0.51 \\
\hline & lsland & 0.16 & & Agency & 0.54 \\
\hline & Charlton & 0.50 & & & \\
\hline & Harriatte & 0.57 & 10 & Valsetz & 0.32 \\
\hline & Todd & 0.36 & & Devils (AC) & 0.23 \\
\hline & Three Creek & 0.44 & & North Tencile & 0.32 \\
\hline & Doris & 0.21 & & Tahkeniteh & 0.29 \\
\hline & Badger & 0.31 & & Triangie & 0.65 \\
\hline & $5 \cot t$ & 0.47 & & Siltecos & 0.48 \\
\hline & Heavenly Twin & 0.29 & & Tenale & 0.35 \\
\hline & Rowich & 0.46 & & Paselia & 0.63 \\
\hline & Devils (DES) & 0.43 & & Davis & 0.57 \\
\hline & Lower Eddeeleo & 0.50 & & & \\
\hline & iorrey & 0.34 & 11 & Collaro & 0.35 \\
\hline & Fish (UR) & 0.50 & & Clear (HC) & 0.47 \\
\hline & Sunent & 0.38 & & Clear (SC) & 0.20 \\
\hline & Laya & 0.54 & & Munse! & 0.22 \\
\hline & Fouraile & 0.36 & & Honon & 0.45 \\
\hline & Lower Erad Bell & 0.39 & & Bull Run & 0.23 \\
\hline & nitler & 0.57 & & Odell & 0.35 \\
\hline & Little Cultus & 0.30 & & Crescent & 0.57 \\
\hline & EIL (OES) & 0.17 & & & \\
\hline & Lost (WIL) & 0.48 & 12 & Sunset & 0.34 \\
\hline & Little Laya & 0.34 & & Oswego & 0.34 \\
\hline & 5old & 0.54 & & & \\
\hline & Fish (RR) & 0.28 & 13 & Abert & 0.00 \\
\hline & Lake O' Yoods & 0.28 & & & \\
\hline & Cultus & 0.40 & 11 & Linton & 0.31 \\
\hline & Di asont & 0.40 & & Sparts & 0.46 \\
\hline & Fish (HL) & 0.56 & & Mirror & 0.21 \\
\hline & Fish (PUR) & 0.51 & & & \\
\hline & Walten & 0.54 & 15 & Maldo & 0.57 \\
\hline & je!:ntrent & 0.51 & & South iwin & 0.48 \\
\hline & Mogune & 0.27 & & Horth Tman & 0.34 \\
\hline & inthony & $i .48$ & & Pauina & 0.60 \\
\hline & & & & $5 \times c$ & \\
\hline
\end{tabular}


TABLE IX

SECONDAFY K-MEANS CLLISTER ANALYSIS RESULTS

GROUP \& L-Y ECOSYSTEM DIST. FROM CENTROID GROUP । L-W ECOSYSTEM DIST. FROM CENTEOID

\begin{tabular}{|c|c|c|c|c|c|}
\hline \multirow[t]{3}{*}{8.1} & Yarriette & 0.37 & 8.4 & IsI and & 0.16 \\
\hline & Little Cultus & 0.30 & & Heavenly Twin & 0.29 \\
\hline & Anthony & 0.48 & & Devils (DES) & $0.1 j$ \\
\hline \multirow[t]{2}{*}{ : } & Stranoerry & 0.39 & & Torrey & 0.34 \\
\hline & & & & Lost (HIL) & 0.48 \\
\hline \multirow[t]{15}{*}{8.2} & Esigrant & 0.41 & & Little Laya & 0.34 \\
\hline & Todd & 0.36 & & Gold & 0.54 \\
\hline & Badgger & 0.31 & & Malton & 0.54 \\
\hline & Scott & 0.47 & & & \\
\hline & Mowich & 0.46 & 8.5 & Charlton & 0.50 \\
\hline & Lower Eddeeleo & 0.50 & & Three Ereek & 0.14 \\
\hline & Fish (UR) & 0.50 & & Doris & 0.21 \\
\hline & Fouraile & 0.36 & & Suneit & 0.38 \\
\hline & Loker Ersa Bell & 0.39 & & Lava & 0.54 \\
\hline & Miller & 0.57 & & Fish (RR) & 0.28 \\
\hline & Elk (DES) & 0.17 & & Lake $0^{\prime}$ Noods & 0.28 \\
\hline & Cultus & 0.40 & & Di asond & 0.40 \\
\hline & Olive & 0.28 & & Fish (PHR) & 0.51 \\
\hline & Jubilee & 0.37 & & & \\
\hline & & & 8.6 & Fish (ML) & 0.56 \\
\hline \multirow[t]{2}{*}{8.3} & Morgan & $0.7 !$ & & Delintaent & 0.54 \\
\hline & & & & Mogone & 0.77 \\
\hline
\end{tabular}

GROUP — L-Y ECOSYSTEH DIST. FROK CENTROID

\begin{tabular}{|c|c|c|}
\hline 9.1 & $\begin{array}{l}\text { Harion } \\
\text { Elk (WIL) } \\
\text { Suttle } \\
\text { Agency }\end{array}$ & $\begin{array}{l}0.54 \\
0.22 \\
0.5 ! \\
0.54\end{array}$ \\
\hline 9.2 & $\begin{array}{l}\text { Hoanink } \\
\text { Threenile } \\
\text { Cullaby } \\
\text { Floras } \\
\text { Sutton } \\
\text { Lytle } \\
\text { Croft } \\
\text { Mercer } \\
\text { Eel }\end{array}$ & $\begin{array}{l}0.12 \\
0.22 \\
0.40 \\
0.27 \\
0.33 \\
0.11 \\
0.19 \\
0.35 \\
0.14\end{array}$ \\
\hline 9.3 & $\begin{array}{l}\text { Trilliun } \\
\text { Lost (HR) } \\
\text { Wahtud } \\
\text { Ollalie }\end{array}$ & $\begin{array}{l}0.47 \\
0.39 \\
9.58 \\
0.46\end{array}$ \\
\hline
\end{tabular}

1 This table qenerated on SUPERCALC-? spreaosizeet arogran. 
CHAPTER VI

DISCUSSION AND CONCLUSIONS

The purpose of this thesis is to identify the most typical natural lake-watershed ecosystems in Oregon. Through principle components factor analysis, the most important combinations of variables selected to characterize the lake systems were identified. Cluster analys is established groups of similar systems based upon those common factors. The mean distance from each groups' centroid defines the most statistically typical lake-watershed ecosystem for each group (Table X).

\section{TABLE $X$}

TYPICAL LAKE-WATERSHED ECOSYSTEMS AND ASSOCIATED FACTORS AND VARIABLES

\begin{tabular}{|c|c|c|c|}
\hline Cluster \# & $\begin{array}{l}\text { Associated } \\
\text { Factor(s) } \\
\end{array}$ & $\begin{array}{l}\text { Associated } \\
\text { Variables } \\
\end{array}$ & $\begin{array}{l}\text { Statistically Typical } \\
\text { L-W ecosystem } * *\end{array}$ \\
\hline 1 & $\mathrm{II}^{*}, \mathrm{IV}$ & $\mathrm{DBr}$ & Squaw Lake $(g)$ \\
\hline 2 & $I^{*} V^{*}, V^{*} I^{*}, I I I^{*}$ & $\begin{array}{l}\text { DBr, Lu (W), Avg z, } \\
\text { Max Z,V,TRt, SO }\end{array}$ & Crater Lake $(p)$ \\
\hline 3 & $\mathrm{II}^{*}, \mathrm{III}^{*}, \mathrm{IV}^{*}$ & $A(B), M A F, S D Y, A(L)$ & Upper Klamath Lake (m) \\
\hline 4 & IV ${ }^{\star}$, II & Prec ip, $R 0, A-T p, T p$ & Upper Cow Lake (g) \\
\hline 5 & I & $\operatorname{LU}(0), M E I$ & Minam Lake $(p)$ \\
\hline 6 & I I I & MAF, SDY, A-Tp, TRt & Crump Lake (m) \\
\hline 7 & $I^{*}, I I I, V$ & SD, Tp, MEI & Summer Lake (indet.) \\
\hline 8.1 & IV & Elev, RO & Little Cuitus Lake (p) \\
\hline 8.2 & II (moderate) & $\operatorname{Avg} z$, Max $Z$, TRt & Cultus Lake $(p)$ \\
\hline
\end{tabular}


TABLE $\times$ (continued)

TYPICAL LAKE-WATERSHED ECOSYSTEMS AND ASSOCIATED FACTORS AND VARIABLES

\begin{tabular}{|c|c|c|c|}
\hline Group \# & $\begin{array}{l}\text { Associated } \\
\text { Factor }(\mathrm{s})\end{array}$ & $\begin{array}{l}\text { Associated } \\
\text { Variables }\end{array}$ & $\begin{array}{l}\text { Statistically Typical } \\
L-W \text { ecosystem } * *\end{array}$ \\
\hline 8.3 & IV & Precip, RO,A-Tp & Morgan Lake (p) \\
\hline 8.4 & I & $V, T R t, T p, M E I$ & Gold Lake $(p)$ \\
\hline 8.5 & IV & Elev, $\mathrm{DBr}, \mathrm{Lu}(0)$ & Summ it Lake $(p)$ \\
\hline 8.6 & I & $R 0, A-T p, A(L)$ & Delintment Lake $(\mathrm{g})$ \\
\hline 9.1 & $I I^{*}, V$ & $\operatorname{Lu}(0)$, TRt & Suttle Lake (p) \\
\hline 9.2 & $I V^{*}, I, I I$ & Precip, $R O, A(L)$, & Ee 1 Lake $(p)$ \\
\hline 9.3 & III ${ }^{*}$, IV & $\begin{array}{l}\text { Prec ip, SDY, } A-T p \text {, } \\
A(L), S D, T p\end{array}$ & Wahtum Lake $(p)$ \\
\hline 10 & II I & $\operatorname{MAF}, A(L)$, TRt & Siltcoos Lake (m) \\
\hline 11 & IV & $\mathrm{RO}, \mathrm{DBr}, \mathrm{MEI}$ & $\begin{array}{l}\text { Collard Lake }(p) \\
\text { Ode } 11 \text { Lake }(p)\end{array}$ \\
\hline 12 & IV & Elev,Lu(U),Tp & $\begin{array}{l}\text { Sunset Lake }(p) \\
\text { Oswego Lake }(p)\end{array}$ \\
\hline 13 & $I^{\star}, I I I^{*}$ & MAF, TRt, ATK, MEI & Abert Lake (m) \\
\hline 14 & I & $\operatorname{Lu}(0)$, TRt ,SD & Linton Lake $(p)$ \\
\hline 15 & II & $\mathrm{DBr}, \mathrm{Lu}(\mathrm{W}), \mathrm{TRt}$ & South Twin Lake (g) \\
\hline
\end{tabular}

* $=$ primary factor

** = correspondence to typical portion of ecoregion

$(p)=$ poor correspondence

$(m)=$ moderate correspondence

$(g)=$ good correspondence

(indet) $=$ indeterminate relationship

Clusters $1,2,3,6,7,8.3$, and 13 are composed of single members, respectively, Squaw Lake, Crater Lake, Upper Klamath, Crump, Summer, Morgan, and Abert Lake. The characteristics of these systems 
make them typical unto themselves; they are unique. It is also of significance that the associated factors and variables representing these unique ecosystems are measures of both the watersheds and the lakes themselves.

The remaining clusters are composed of two or more members, with the largest number occurring in cluster 8.2 with fourteen lake systems. In the case of cluster 12, Sunset and 0swego Lakes were the same distance from the centroid value and they are considered together as unique systems. In cluster 11, Collard and 0dell Lakes are also have the same distance values and are both statistically typical. In all, 24 lake-watershed ecosystems have been identified as being typical, baseline ecosystems.

It is informative to compare the relative geographic locations of the statistically typical lake-watershed systems to the most-typical portions of Oregon ecoregions. In general, the correspondence between the boundaries of the typical systems watersheds and the boundaries of the most-typical areas of ecoregions is poor (Table $X$ ). In some instances the watersheds extend across ecoregion boundaries or encompass both parts of both generally-typical and most-typical areas, so the correspondence is moderate only or, as in the Summer Lake system, is indeterminate. The lake-watershed ecosystems that have good correspondence with the most-typical portions of their respective ecoregions are Squaw Lake in the Sierra Nevada ecoregion, South Twin Lake in the Eastern Cascades Slopes and Foothills ecoregion, Upper Cow Lake in the Snake River Basin/High Desert ecoregion, and Delintment Lake in the Blue Mountain ecoregion. 
The general lack of correspondence between boundaries of the most-typical areas of Oregon ecoregions and the boundaries of the statistically typical lake-watershed ecosystems can be explained in two ways. First, the ecoregion concept is based upon four mapped terrestrial components of which only one, land use, was incorporated into this study's data base. Land surface-form, potential natural vegetation, and soils were not variables used in this classification. Second, the methodology of this thesis is a "bottom-up" approach from the site-specific base to a more general one. The ecoregion model is a "top-down" approach based on broad-scale measurement of ecosystem parameters, so does not depict site-lever details. The overall disagreement between the boundaries, however, does not negate the utility of either method. Most importantly, both are independently derived syntheses of many environmental characteristics; both have similar goals -- to help researchers and managers to better understand the regional patterns of ecosystem conditions and to acquire knowledge of the "typicalness" of individual ecosystems.

\section{CONCLUSIONS}

Regardless of the purpose of a classification of environmental systems, its organizational structure, and the selection of variables used, all such classifications represent an intermediate perspective between conceptual simplicity and complex reality. In some way, each of the six-thousand or more lake-watershed ecosytems in Oregon is unique, but managerial logistics cannot hope to address each system individually. Only by categorizing and typifying systems as complex as 
lakes in Oregon, so that general relationships of groups of lake-watershed ecosystems can be seen, will it be possible to effectively monitor and manage them. Based upon the results of this thesis, it is apparent that similar lake-watershed ecosystems, defined on the basis of having significant correspondence between both watershed and in-lake morphometric, hydrologic, and biochemical characteristics, can be identified in a regional context for the prioritizing of lakes for management and for research. 
CHAPTER VII

\section{SUGGESTED RESEARCH}

As in many studies of the characteristics of landscape, the groups and typical, representative natural lake-watershed ecosystems in Oregon developed in this thesis are not intended to provide the final answer to regional lake management or to questions about ecosystems potential. Rather, it is hoped that these results provide a logical and meaningful framework within which subsequent investigations and experiments can be planned and implemented. The purpose of this chapter is to suggest further research that will help to clarify the complex interrelationships between oregon lakes and their watersheds.

One aspect of lake-watershed ecosystems desperately needed in Oregon, and elsewhere, is a method to more accurately estimate surface-water runoff and stream discharge in ungaged systems. Surface runoff and streamflow are most often the primary water inputs to lakes, and they are necessary measures in several empirical equations such as in the calculation of lake retention time, mean annual flood, suspended sediment contributions, and nutrient budgets. More detailed information is especially needed of surface runoff contributions to lakes in watersheds underlain by porous basaltic strata and/or mantled with pumice.

Another research possibility is the development of a regional vulnerablity index for Oregon lake-watershed ecosystems -- the term 
"Vulnerability" taken to mean a sensitivity to changes in water quality. Such a method is outlined in States, et al. (1978) and in Sargent and Sargent (1979) in the form of an aquatic vulnerablity matrix. Researchers undertaking such a project should focus on land uses in the watershed and adjacent to lakes, land development potentials, watershed geology and soils in terms of nutrient concentrations and availablity, and on erosion potentials.

Perhaps the most comprehensive approach to evaluating lake systems is to utilize the problem-solving capabilities of a Geographic Information system (GIS). Water quality and quantity, land use, geology, soils, climate, and watershed hydrologic characteristics, measured at moderate scales (e.g. 1:100,000), can be appropriately used within a GIS. Such a procedure could have great potential for analytical and decision-making purposes. Students, technicians, and managers alike should become familiar with the concepts and applications of GIS for regional water planning and assessment, particularly since these powerful tools become more commonplace in the private and public sectors.

The demands on water resources such as lakes are increasing exponentially. The continued multiple-use of lakes and demands for high-quality lake-system conditions, necessitates a corresponding increase in management and research. All too often, however, the rationale of water management and research goals is purely biological, or hydrological, or political. It must be recognized that interdisciplinary management and research efforts, as well as effective, ongoing communication and education concerning lakes as ecosystems, are 
requisite to practical water resources conservation and use. 


\section{REFERENCES}

Alexander, R.R. 1985. Major habitat types, community types, and plant communities in the Rocky Mountains. General Technical Report, RM-123, Rocky Mounta in Forest and Range Exp. Sta., USDA Forest Service, Fort Collins, CO, 105pp.

Allen, J.A. 1892. The geographic distribution of North American mammals. Bul1. Amer. Museum Nat. History, 4:199-243.

Anderson, W. U.S. Army Corps of Engineers, Walla Walla District Office, WA. Personal communication, July 15, 1987.

Arno, S.F. 1979. Forest regions of Montana. USDA Forest Service, Research Paper, INT-218, Ogden, UT, 22pp.

Bailey, R.G. 1976. Ecoregions of the United States (map). USDA Forest Service, Ogden, UT.

- 1980. Description of the ecoregions of the United States. U.S. Department of Agriculture, Miscellaneous Publication 1391,

Washington, D.C., 65pp.

- 1984. Testing an ecosystem regionalization. J. Environmental Management, 19:239-248.

Bailey, Robert G., Robert D. Pfister, and Jan A. Henderson. 1978. Nature of land and resource classification- a review. J. Forestry, $30: 650-655$.

Bailey, Robert G., S.C. Zoltai and E.B. Wiken. 1985. Ecological regionalization in Canada and the United States. Geoforum, $16(3): 265-275$.

Berndt, H.W. 1970. Forest land-use and streamflow in central oregon. USDA Forest Service, Pacific Northwest Forest and Range Experiment Station, Research Paper, PNW-93.

Berry, B.J.L. 1964. Approaches to regional analysis: a synthesis. Annals, Assoc. Amer. Geog., 54:2-11.

Beschta, R.L. 1978. Long-term pattern of sediment production following road construction and logging in the Oregon Coast Range. Water Resources Research, 14(6):1011-1016. 
Bormann, F.H. and G.E. Likens. 1967. Nutrient cycling. Science, $155: 424-429$.

Bortleson, G.E., N.P. Dion, and J.B. McConnel1. 1974. A method for the relative classification of lakes in the state of Washington from reconnaissance data. U.S. Geological Survey, Water Resources Investigations, $\mathrm{pp}$. 37-74.

Bruce, R.G.H., S.K. Morell, and H.E. Stel. 1975. The application of multivariate analys is to regional survey. J. Environmental Management, 3:151-166.

Carlson, R.E. 1977. A trophic state index for lakes. Limnology and Oceanography, $22(2): 361-369$.

- 1979. A review of the philosophy and construction of trophic state indices. In: T.E. Maloney (ed.), Lake and Reservoir Classification systems, U.S. Environmental Protection Agency, Corvallis Environmentai Research Laboratory, 240pp.

Chorley, R.J. 1969. The drainage basin as the fundamental geomorphic unit. p.77-100. In: R.J. Chorley (ed.), Water, Earth, and Man. Methuen Press, London, 588pp.

Ciecka, J., R. Fabian, and D. Merilatt. 1980. Eutrophication measures for small lake water quality management. Water Resources Bu11., Amer. Water Res. Assoc., 16(4):681-689.

Cole, J.P. and C.M.A. King. 1968. Quantitative Geography. John Wiley and Sons, New York, NY, 692pp.

Daubenmire, R. 1952. Forest vegetation of Northern Idaho and adjacent Washington, and its bearing on concepts of vegetation mapping and classification. Ecol. Monograph, 22:301-330.

Daubenmire, R. and J.B. Daubenmire. 1968. Forest vegetation of Eastern Washington and Northern Idaho. Technical Bul1.60, Washington Agricultural Exp. Sta., Washington State Univ., Puilman, WA, 104pp.

Deevey, E.S. 1940. Limnological studies in Connecticut, V: a contribution to regional limnology. Amer. J. Sci., 238:717-741.

- 1984. Stress, strain, and stability of lacustrine ecosystems.

In: E.Y. Hayworth and J.W.G. Lund (eds.), Lake Sediments and

Environmental History, (pp. 203-229). Univ. Of Minnesota Press, Minneapolis, MN, 465pp.

Dice, L.R. 1943. The Biotic Provinces of North America. Univ. Michigan Press, Ann Arbor, MI. 
Dillon, P.J. and F.H. Kirchner. 1975. The effect of geology and land-use on the export of phosphorus from watersheds. Water Research, $9: 135-148$.

Dillon, P.J. and F.H. Rigler. 1975. A simple method for predicting the capacity of a lake for development based upon lake trophic status. J. Fish. Res. Board Can., 32(9):1519-1531.

Dobson, H.F. 1974. A summary and comparison of nutrients and related water quality in lakes Erie, Ontario, Huron, and Superior. J. Fish. Research Board Canada, 31:731-738.

Donahue, R.L., R.W. Miller, and J.C. Shickluna. 1983. Soils: An Introduction to Soils and Plant Growth. Prentice Hall, Inc., Englewood CTiffs, NJ, 667pp.

Dunne, T. and L.B. Leopold. 1978. Water in Environmental Planning. W.H. Freeman and Company, San Francisco, 818pp.

Edmonson, W.T. 1980. Secchi disk and chlorophy11. Limnology and Oceanography, 25(2):378-379.

Eyles, R.J. 1971. A classification of West Malaysian drainage basins. Annals, Asoc. Am. Geog., 61(3):460-467.

Fletcher, H.E. and L.R. Rich. 1955. Classifying southwestern watersheds on the basis of water yields. J. of Forestry, 53:196-202.

Forbes, S.A. 1887. The lake as a microcosm. Reprinted 1925 in Bull. Illino is Nat. History Surv., 15:537-550.

Franklin, J.F. 1965. Tentative ecological provinces with in the True fir-Hemlock forest areas of the Pacific Northwest. Research Paper, PNW-22, Pacific Northwest Forest and Range Exp. Sta.,, USDA Forest Service, $31 \mathrm{pp}$.

Goldman, C.R. and A.J. Horne. 1983. Limnology. McGraw-Hill Book Co., New York, $464 \mathrm{pp}$.

Gottschalk, L.C. 1957. Problems of predicting sediment yields from watersheds. Transactions Amer. Geophysical Union, 38(6):885-888.

- 1964. Reservoir sedimentation. In: V.T. Chow (ed.), Handbook of Applied Hydrology. McGraw-Hill, New York.

Gregory, K.J. and D.E Walling. 1971. Field measurements in the drainage basin. Geography, 56:277-292.

and - 1973. Drainage Basin Form and Process. John

Wiley and Sons, New York, NY, 458pp. 
Griffith, G.E., J.M. Omernik, and A.J. Kinney. (in press). Interpreting patterns of lake alkalinity in the Upper Midwest region, USA. In: "Lake and Reservoir Management III", Proceedings of the Sixth Annual International Symposium, North American Lake Management Society, November 1986, Portland, OR.

Grobler, D.C. and M.J. Silberbauer. 1985. The combined effect of geology, phosphate sources, and runoff on phosphate export from drainage basins. Water Research, 19(8):975-983.

Hayes, F.R. and E.H. Anthony. 1964. Productive capacity of North American lakes as related to the quantity and the trophic level of fish, the lake dimensions and the water chemistry. Trans. Amer. Fish. Soc., 93:53-57.

Heiskary, S.A., D.P. Larsen, and C.B. Wilson. (in press). Analys is of regional lake water quality patterns: implications for lake and reservoir management in Minnesota. In: "Lake and Reservoir Management III", Proceedings of the Sixth Annual International Symposium, North American Lake Management Society, November 1986, Portland, 0 R.

Horne, A.J., J.D. Newbold, and M.M. Tilzer. 1975. The productivity, mixing modes, and management of the world's lakes. Limnology and Oceanography, 20:663-666.

Hughes, R.M., D.P. Larsen, and J.M. Omernik. 1984. Regional reference sites: a method for assessing stream ecosystems. Environmental Management, 10:629-635.

Hughes, R.M., E. Rexstad, and C.E. Bond. 1987. The relationships between aquatic ecoregions, river basins, and physiographic provinces to the ichthyographic regions of Oregon. Copeia, 1987:423-432.

Hulsing, H. and N.A. Kallio. 1964. Magnitude and frequency of floods in the United States: Part 14, Pacific STope Basins in Oregon and Lower Columbia River Basin. U.S. Geological Survey, Water Supply Paper No.1689, 320pp.

Hutchinson, G. Evelyn. 1957. A Treatise on Limnology: Vol. 1, Geography, Physics, Chemistry. John WiTey and Sons, New York, NY, 1015pp.

- 1969. Eutrophication, past and present. In: Eutrophication: Causes, Consequences, Correctives, (pp. 17-26). National Academy of Sciences Publ. No. 1700 .

- 1973. Eutrophication: the scientific background of a contemporary practical problem. Amer. Sci., 61:269-279.

Johnson, D.M., R.R. Peterson, D.R. Lycan, J.M. Sweet, M.E. Neuhaus, and A.L. Schaedel. 1985. Atlas of Oregon Lakes. Oregon State Univ. Press, Corvallis, OR, $317 \mathrm{pp}$. 
Johnston, R.J. 1976. Grouping and regionalising: some methodological and technical observations. Economic Geography, 46:293-305.

- 1978. Multivariate Statistical Analysis in Geography.

Longman, Inc., New York, NY, 280pp.

Kirchner, W.B. 1975. An examination of the relationship between drainage bas in morphology and the export of phosphorus. Limnol. and Oceanog., $20(2): 267-270$

Kirchner, W.B. and P.J. Dillon. 1975. An empirical method of estimating the retention of phosphorus in lakes. Wat. Res. Res., 11:182-183.

Küchler, A.W. 1951. The relationship between classifying and mapping vegetation. Ecology, 32:275-283.

- 1964. Manual to accompany the map of potential natural vegetation of the conterminous United States. Amer. Geog. Soc. Spec. Publ. 36.

Lacate, D.S. 1961. A review of land-type classification and mapping. Land Economics, $37(3): 271-278$.

Larson, D.P., J. M. Omernik, and R.M. Hughes. 1985. Development of Aquatic Ecoregions, (unpubl ished manuscript). U.S. Environmental Protection Agency, Corvall is Environmental Research Laboratory, Corvallis, OR, $17 \mathrm{pp}$.

Larson, D.P., J.M. Omernik, R.M. Hughes, C.M. Rohm, T.R. Whittier, A.J. Kinney, A.L. Gallant, and D.R. Dudley. 1986. The correspondence between spatial patterns in fish assemblages in 0hio streams and aquatic ecoregions. J. Environmental Management, $10(6): 815-828$.

Larson, D.W. 1972. Cultural impact in lake evolution. In: Proceedings of a Seminar on Man and Aquatic Communities, (pp. 57-70), water Resources Research Institute, Oregon State Univ., Corvallis, OR.

Leopold, L.B., M.G. Wolman, and J.P. Miller. 1964. Fluvial Processes in Geomorphology. W.H. Freeman and Company, San Francisco, 522pp.

Leopold, L.B. and 0. Marchand. 1968. On the quantitative inventory of riverscape. Wat. Res. Res., 4(4):709-717.

Lerman, A. 1974. Eutrophication and water quality of lakes: control by water residence time and transport to sediments. Hydro. Sci. Bu 11., 19:25-34.

Likens, G.E. 1975. Primary productivity of inland aquatic ecosystems. In: H.L. Lieth and R.H. Whittaker (eds.), Primary Productivity of the Biosphere, (pp. 185-202). Springer-VerTag, New York, NY. 
Likens, G.E. and F.H. Bormann. 1974. Linkages between terrestrial and aquatic ecosystems. Bioscience, 24(8):447-456.

Likens, G.E., F.H. Bormann, R.S. Pierce, J.S. Eaton, and N.M. Johnson. 1977. Biogeochemistry of a forested watershed. Springer-Verlag, New York, NY, 146pp.

Lindeman, R.L. 1942. The trophic dynamic aspect of ecology. Ecology, $23: 399-418$.

Lotspeich, F.B. 1980. Watersheds as the basic ecosystem: this conceptual framework provides a basis for a natural classification system. Water Resources Bu11., 16:581-586.

Lotspeich, F.B. and W.S. Platts. 1982. An integrated land-aquatic classification system. North Amer. J. Fish. Management, 2:138-145.

Mackin, J.H. 1948. Concept of the graded river. Geol. Soc. Amer. Bul1., $59: 463-512$.

Maloney, T.E. 1979. Lake and Reservoir Classification Systems. U.S. Environmental Protection Agency, Corvallis Environmental Research Laboratory, Corvali is, OR, 240pp.

Matalas, G.N. and B.J. Reiher. 1967. Some comments on the use of factor analysis. Water Resources Research, 3:213-223.

Mather, P. and J.C. Doornkamp. 1970. Multivariate analysis in geography with particular respect to drainage bas in morphometry. Transactions Inst. British Geog., 51:163-187.

Merriam, C.H. 1898. Life zones and crop zones of the United States. BuT1. Div. Biol. Survey, U.S. Department of Agriculture, 10:1-79.

Moss, B. 1980. Ecology of Fresh Waters. Blackwell Scientific Pub., Halsted Press, New York, NY, 332pp.

National Academy of Science and National Academy of Engineering. 1972. Water Quality Criteria. A report of the Committee on Water Quality Criteria, Washington, D.C.

Naumann, E. 1927. Ziel and hauptprobleme der regionale limnologie. Bot. Notiser, $1927: 81-103$.

Northcote, T.G. 1980. Morphometrically conditioned eutrophy and its amelioration in some British Columbia lakes. In: J. Barica and L.R. Mur (eds.), "Hypertrophic Ecosystems", Developments in Hydrobiology 2, (pp. 305-315), W. Junk Publishers, The Hague.

Northcote, T.G. and P.A. Larkin. 1956. Indices of productivity in British Columbia lakes. J. Fish. Research Board Can., 13:515-540. 
Nygaard, G. 1955. On the productivity of five Danish waters. Verh. Int. Vere in Limno1., 12:123-133.

Odum, E.P. 1969. Air-land-water = an ecological whole. J. Soil Water Conserv., 24(1):4-7.

Ohle, W. 1956. Bioactivity, production, and energy utilization of lakes. Limnology and Oceanography, 1:139-149.

Omernik, J.M. 1977. Nonpoint source -- stream nutrient level relationships: a nationwide study. U.S. Environmental Protection Agency, Corvallis Environmental Research Laboratory, Corvallis, OR, $149 \mathrm{pp}$.

. 1987. Ecoregions of the conterminous United States. Annals, Assoc. Amer. Geog., $77(1): 118-125$.

Omernik, J.M. and A.C. Gallant. 1986. Ecoregions of the Pacific Northwest. U.S. Environmental Protection Agency, CorvalTis Environmental Research Laboratory, Corvallis, OR, 39pp.

O'Sullivan, P.E. 1979. The ecosystem-watershed concept in the environmental sciences -- a review. International J. Environmental Studies, 13:273-281.

Petersen, R.R. Portland State University, Biology Department. Personal Communication, June 2, 1987.

Phillips, K.E. 1968. Hydrology of Crater, East and Davis Lakes, Oregon. U.S. Geological Survey, Water Supply Paper, 1859-E, 45pp.

Phillips, K.E. and A.S. Van Denburgh. 1971. Hydrology and geochemistry of Abert, Summer, and Goose Lakes, and other closed bas in lakes in South-Central Oregon. U.S. Geological Survey, Professional Paper, 502-8, 86pp.

Rawson, D.S. 1955. Morphometry as a dominant factor in the productivity of large lakes. Verh. Int. Verein. Limnol., 12:164-175.

Reckhow, K.H. 1979. Quantitative Techniques for the Assessment of Lake Quality. U.S. Environmental Protection Agency, Office of Water PTanning and Standards, 146pp.

Reimers, N., J.A. Maciolek, and E.P. Pister. 1955. Limnological study of the lakes in Convict Creek Basin, Mono County, California. U.S. Fish and Wildlife Service, Fisheries Bull. 103, 56:437-503.

Rickert, D.A., H. Hazen, J. Jackson, D.M. Anderson, G.L. Beach, E. Suwijn, and E.T. Benton. 1978. Oregon's Statewide Assessment of Nonpoint Source Problems. State of Oregon, Department of Environmental Quality, Water Quality Program, 71pp. and plates 1-8. 
Rodhe, W. 1969. Crystallization of eutrophication concepts in Northern Europe. In: Eutrophication: Causes, Consequences, Correctives, (pp. 50-67). National Academy of Sciences PubT. 1700 .

Rohm, C.M., J.W. Geise, and C.C. Bennett. 1987. Evaluation of an aquatic ecosystem classification of streams in Arkansas. J. Freshwater Ecol., 4:127-140.

Rowe, J.S. and J.W. Sheard. 1981. Ecological land classification: a survey approach. Environmental Management, 5(5):451-464.

Ryder, R.A. 1965. A method for estimating the potential fish production from north-temperate lakes. Transactions Amer. Fish. Soc., $94: 214-218$.

Sakomoto, M. 1966. Primary production by phytoplankton community in some Japanese lakes and its dependence on lake depth. Arch. Hydrobiol., $62: 1-28$.

Sargent, F.0. and B.P. Sargent. 1979. Rural Water Planning. Fredrick 0. Sargent Publ., South Burlingtoon, VT, 199pp.

Shannon, E.E and P.L. Brezonik. 1972a. Eutrophication analysis: a multivariate approach. J. San. Eng., Div. ASCE, 98(1):37-57.

. 1972b. Relationships between lake trophic state and nitrogen and phosphorus loading rates. Environmental Sci. Tech., 6:719-725.

Shapiro, J. 1979. The current status of lake trophic indices. In: T.E. Maloney (ed.), Lake and Reservoir Classification Systems, Tpp.

53-99). U.S. Environmental Protection Agency, Corvaltis

Environmental Research Laboratory, Corvallis, OR, $240 \mathrm{pp}$.

Sheldon, A.L. 1976. A quantitative approach to the classification of in land waters. In: J.V. Krutilla (ed.), Natural Environments: Studies in Theoretical and Applied Analysis, (pp. 205-261). John Hopkins Univ. Press, Baltimore, MD.

SIGSTAT. 1979. Biomedical Computer Program (BMD). Univ. of California Los Angeles, CA.

Smith, D.M. 1975. Patterns in Human Geography: An Introduction to Numerical Methods. Crane, Russak and Company, Inc., New York, NY, $373 \mathrm{pp}$.

Snyder, W.M. 1962. Some possibilities for multivariate analys is in hydrologic studies. J. Geophysical Research, 67(1):721-729.

Sokal, R.R. 1974. Classification: purposes, principies, progress, prospects. Science, 185:1115-1123. 
States, James B., P.T. Haug, T.G. Shoemaker, L.W. Reed, and E.B. Reed. 1978. A Systems Approach to Ecological Baseline Studies. Ecology Consultants, Inc., Fort Collins, CO. Prepared for U.S. Fish and Wildlife Service, Office of Biological Services, Western Energy and Land Use Team. FWS/OBS-78/21-3-78.

Strom, F.H. 1930. Observations on lake productivity and mixing in the Adirondak Mountains of New York. New York Sci. Soc. Bull..

Swanston, D.N. and F.J. Swanson. 1976. Timber harvesting, mass erosion, and steepland geomorphology in the Pacific Northwest. In: D.R. Coates (ed.), Geomorphology and Engineering, (pp. 199-221). Dowden, Hutchinson, and Ross Publ., Stroudsburgh, PA.

Taub, F.B. (ed.). 1984. Ecosystems of the Worid: Lakes and Reservoirs, No. 23. Elsevier Press, New York, NY.

Taylor, P.J. 1977. Quantitative Methods in Geography. Waveland Press, Inc., Prospect Heights, IL, 386pp.

U.S. Department of Agriculture, Soil Conservation Service. 1971. Average Annual Runnof, Oregon, (unpublished map, $1: 2,000,000$ ). Port tand, OR.

U.S. Department of Agriculture, Soil Conservation Service. 1975. Average Annual Sediment Yield, Oregon, (unpublished map, 1:100,000).

Portland, $O R$.

U.S. Environmental Protection Agency. 1974. An approach to a relative trophic index system for classifying lakes and reservoirs. Working Paper No. 24.

- 1977. An evaluation of the National Eutrophication Survey data. Working Paper No. 900, Corvall is Environmental Research Laboratory, Corvallis, OR, and Environmental Monitoring and Support Laboratory, Las Vegas, NV, 76pp.

, Region X. 1978a. Repor't on Suttle Lake, Jefferson County, Oregon. Working Paper No. 833, Corvall is Environmental Research Laboratory, CorvalTis, OR, $21 \mathrm{pp}$.

, Region X. 1978b. Report on Waldo Lake, Lane County, Oregon. Working Paper No. 834, Corvall is Environmenta? Research Laboratory, Corvallis, OR, 14pp.

U.S. Geological Survey. Water Resource Data for Oregon, Water Year 1979. USGS Water-Data Report, OR-79-1, 743pp.

Uttormark, P.D., J.D. Chapin, and K.M. Green. 1975. Estimating Nutrient Loading of Lakes From Nonpoint Sources. U.S. Environmental Protection Agency, Office of Research and Development, Corvallis, OR, $165 \mathrm{pp}$. 
Uttormark, P.D. and J.P. Wa11. 1974. Nutrient assessments as a bas is for lake management priorities. In: E.J. Middlebrooks et al. (ed.s), Biostimulation and Nutrient Assessment, (pp. 221-240). Ann Arbor Science, Ann Arbor, MI.

Vallentyne, J.R., J. Shapiro, and A.M. Beeton. 1969. The process of eutrophication and criteria for trophic state determination. In: Modeling the Eutrophication Process, (pp. 58-67). Proceedings of a workshop at St. Petersburg, FL, November 19-21, 1969.

Vallentyne, J.R. 1974. The Algal Bowl: Lakes and Man. Canadian Department of the Environment, Fisheries and Marine Service, Miscellaneous Spec. Publ. No. 22, 183pp.

Vannote, R.C., G.W. Minsha11, K.W. Cumm ins, J.R. Sedell, and C.E. Cushing. 1980. The river cont inuum concept. Can. J. Fish. Aquat. Sci., 37:130-137.

Vighi, M. and G. Chiandani. 1985. A simple method to estimate lake phoshorus concentrations from natural background loadings. Water Research, 19(8):987-991.

Vollenweider, R.A. 1968. Scientific Fundamentals of the Eutrophication of Lakes and Flowing Waters, with Particular Reference to Nitrogen and Phosphorus as Factors in Eutrophication. Tech. Report, DAS/CSI/68.27.0ECD, Paris. 156pp.

Warren, C.E. 1979. Toward a Classification and Rationale for Watershed Management and Stream Protection. U.S. Environmental Protection Agency, Corvallis Environmental Research Laboratory, Corvallis, OR, $142 \mathrm{pp}$.

Watt, A. 1982. Thesaurus of Geology. Barnes and Noble Books, New York, $192 \mathrm{pp}$.

Welch, E.B., W.H. Chamberlain, and D.E. Spyridakis. 1984. Chemical content of snow and effect of melting on Cascade Mountain lakes. Northwest Science, 58(2):85-93.

Wetzel, R.G. 1975 (lst ed). Limnology. Saunders College Publishing, Philadelphia, PA, 654pp.

1983 (2nd ed). Limnology. Saunders College Publishing, Philadelphia, PA, 767pp.

Whittow, J. 1984. Dictionary of Physical Geography. Penguin Books, New York, $591 \mathrm{pp}$.

Wilkinson, L. 1986. SYSTAT: the system for statistics. SYSTAT, Inc., Evanston, IL. 
Williams, J.R. and H.D. Berndt. 1977. Sediment yield prediction based on watershed hydrology. Transactions Amer. Soc. Agric. Engineers, $20(6): 1100-1104$

Winter, Thomas C. 1977. Classification of the hydrologic settings of lakes in the North Central United States. Water Resources Research, 73(4):753-767. 


\section{APPENDIX A \\ DATA MATRIX FOR SELECTED OREGON LAKE-WATERSHED ECOSYSTEMS}

The following matrix is a tabulation of the morphometric, hydrologic, land use, and chemical data used in the descriptive and statistical analyses of the selected lake-watershed ecosystems in Oregon. 
APPENDIX A

DATA MATRIX FOR SELECTED OREGON LAKE-WATERSHED ECOSYSTEMS

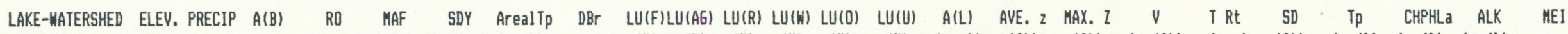

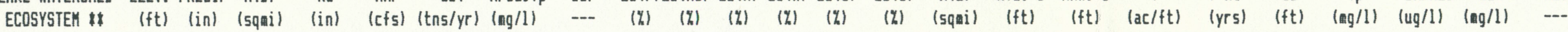

\begin{tabular}{|c|c|c|c|c|c|c|c|c|c|c|c|c|c|c|c|c|c|c|c|c|c|c|c|c|}
\hline ABERT LAKE & 4255 & 16 & 802.91 & 4.1 & 3600.0 & 80291 & .066 & 14.06 & 30.0 & 7.0 & 54.0 & 7.0 & 2.0 & .0 & 57.09 & 7.3 & 11 & 268186 & 4.50 & 8.2 & .140 & 4.001 & 11515.01 & 1577.40 \\
\hline AGENCY LAKE & 4139 & 38 & 229.47 & 36.4 & 1413.0 & 68841 & .054 & 15.79 & 59.0 & 31.0 & 1.0 & 6.0 & 3.0 & .0 & 14.53 & 3.0 & 7 & 28172 & .06 & 2.6 & .194 & --- & 51.0 & 17.00 \\
\hline ANTHONY LAKE & 7131 & 50 & 1.47 & 7.5 & -- & 147 & .040 & 49.00 & 97.3 & .0 & .0 & 2.7 & .0 & .0 & .03 & 9.9 & 32 & 215 & .36 & 18.4 & .004 & 2.10 & 2.0 & .20 \\
\hline BADGER LAKE & 4472 & 70 & 1.13 & 35.0 & 86.6 & 113 & .013 & 16.14 & 94.3 & .0 & .0 & 5.7 & .0 & .0 & .07 & 17.6 & 43 & 704 & .33 & 24.6 & .007 & .40 & 11.0 & .63 \\
\hline BULL RUN LAKE & 3175 & 120 & 2.77 & 82.3 & 279.8 & 277 & .013 & 3.80 & 80.0 & .0 & .0 & 20.0 & .0 & .0 & .73 & 65.6 & 225 & 30554 & 2.51 & 39.0 & .014 & -- & 3.0 & .05 \\
\hline CHARLTON LAKE & 5692 & 40 & .46 & 15.0 & -- & 46 & .013 & 1.89 & 71.4 & .0 & .0 & 28.6 & .0 & .0 & .24 & 35.0 & 95 & 5400 & 14.67 & 36.1 & .004 & .10 & 2.0 & .06 \\
\hline HICKAHOMINY RES & 4280 & 12 & 74.17 & 2.4 & 100.0 & 7417 & .040 & 89.69 & .0 & .0 & 99.0 & 1.0 & .0 & .0 & .83 & 10.0 & 28 & 4700 & .50 & 3.3 & .171 & 3.30 & 46.0 & 4.60 \\
\hline LEAR LAKE (YC) & 99 & 78 & .86 & 50.0 & 28.9 & 258 & .040 & 3.60 & 47.9 & .0 & .0 & 29.2 & 22.8 & .0 & .24 & 40.0 & 80 & 6100 & 2.66 & 11.5 & .007 & 1.53 & 8.0 & .20 \\
\hline LEAR LAKE (SC) & 229 & 65 & 1.51 & 50.0 & 50.4 & 453 & .040 & 3.05 & 65.0 & .0 & .0 & 25.0 & 10.0 & .0 & .50 & 54.0 & 119 & 16600 & 4.12 & 23.0 & -- & -- & 15.0 & .28 \\
\hline COLLARD LAKE & 105 & 78 & .43 & 50.0 & 16.3 & 129 & .040 & 6.42 & 58.0 & .0 & .0 & 16.0 & 26.0 & .0 & .07 & 22.0 & 52 & 900 & .78 & 9.8 & .015 & 4.20 & 11.0 & .50 \\
\hline CRATER LAKE & 6176 & 60 & 6.47 & 38.6 & -- & 647 & .026 & .32 & .0 & .0 & .0 & 77.5 & 22.5 & .0 & 20.53 & 1078.0 & 19321 & 14164100 & 156.50 & 95.1 & .017 & .39 & 40.0 & .04 \\
\hline CRESCENT LAKE & 4839 & 50 & 49.90 & 32.7 & 576.8 & 499 & .040 & 7.02 & 86.4 & .0 & .0 & 11.8 & 1.8 & .0 & 7.10 & 124.0 & 265 & 566600 & 6.50 & 47.6 & .025 & .40 & 10.0 & .08 \\
\hline CROFT LAKE & 10 & 70 & 4.69 & 60.0 & 251.3 & 1407 & .040 & 44.25 & 85.0 & .0 & .0 & 3.0 & 12.0 & .0 & .11 & 8.0 & 16 & 500 & .03 & 11.5 & .023 & .80 & 10.0 & 1.25 \\
\hline CRUMP LAKE & 4475 & 20 & 696.00 & 3.8 & 3100.0 & 169824 & .084 & 58.00 & 16.0 & 4.0 & 71.0 & 3.0 & 5.0 & .0 & 12.00 & 3.0 & 6 & 23000 & .13 & 1.3 & .150 & 29.70 & 64.0 & 21.33 \\
\hline CULLABY LAKE & 8 & 85 & 6.71 & 70.0 & 505.6 & 2013 & .040 & 22.82 & 93.0 & 1.0 & 1.0 & 4.0 & .0 & 1.0 & .29 & 5.0 & 12 & 1000 & .04 & 3.0 & .056 & 2.80 & 11.5 & 2.30 \\
\hline CULTUS LAKE & 4668 & 50 & 33.76 & 25.9 & 267.7 & 3376 & .015 & 27.31 & 93.0 & .0 & .0 & 6.5 & .5 & .0 & 1.24 & 80.0 & 211 & 62900 & 1.35 & 56.4 & .001 & .10 & 1.0 & .01 \\
\hline DAVIS LAKE & 4386 & 48 & 104.90 & 29.6 & 1042.3 & 10490 & .027 & 17.19 & 88.5 & .0 & .0 & 10.5 & 1.0 & .0 & 6.10 & 9.0 & 20 & 35940 & .29 & 10.5 & .016 & 2.10 & 15.0 & 1.67 \\
\hline DELINTMENT LAKE & 5562 & 25 & 1.10 & 9.5 & -- & 110 & .040 & 11.34 & 93.0 & .0 & .0 & 7.0 & .0 & .0 & .10 & 8.0 & 18 & 500 & .90 & 8.9 & .082 & 2.40 & 44.0 & 5.50 \\
\hline DEVILS LAKE IDES & 5440 & 75 & 2.56 & 42.5 & 64.1 & 256 & .013 & 71.11 & 99.0 & .0 & .0 & 1.0 & .0 & .0 & .04 & 3.0 & 10 & 70 & .01 & 9.8 & .072 & 1.10 & 10.0 & 3.33 \\
\hline DEVILS LAKE (MC) & 20 & 101 & 22.94 & 68.9 & 1588.7 & 6882 & .040 & 21.64 & 88.9 & .0 & 3.4 & 4.3 & .0 & 3.4 & 1.06 & 10.0 & 22 & 6600 & .08 & 6.9 & .034 & 2.50 & 24.0 & 2.40 \\
\hline DIAMOND LAKE & 5183 & 60 & 49.10 & 32.8 & 407.0 & 42226 & .040 & 9.78 & 88.0 & .0 & .0 & 9.0 & 3.0 & .0 & 5.02 & 24.0 & 52 & 77100 & 1.50 & 14.8 & .044 & 5.10 & 18.5 & .77 \\
\hline DOG LAKE & 5197 & 18 & 14.71 & 3.5 & -- & 1471 & .040 & 49.86 & 49.2 & .0 & 43.4 & 2.3 & 5.1 & .0 & .30 & 14.0 & 22 & 2600 & .95 & 9.2 & .089 & 11.50 & 42.0 & 3.00 \\
\hline DORIS LAKE & 5310 & 60 & .99 & 35.0 & -- & 99 & .013 & 9.17 & 89.7 & .0 & .0 & 10.3 & .0 & .0 & .11 & 24.0 & 95 & 1600 & .86 & 59.1 & .003 & .20 & 1.0 & .04 \\
\hline EAST LAKE & 6370 & 35 & 7.37 & 10.0 & -- & 737 & .040 & 4.52 & 76.1 & .0 & .0 & 18.2 & 5.7 & .0 & 1.63 & 67.0 & 180 & 69600 & 17.78 & 31.4 & .016 & .90 & 104.0 & 1.55 \\
\hline EEL LAKE & 61 & 68 & 9.45 & 50.0 & 328.2 & 2835 & .040 & 17.03 & 89.5 & .0 & .0 & 10.5 & .0 & .0 & .56 & 34.0 & 65 & 12200 & .48 & 18.7 & .006 & .90 & 12.0 & .35 \\
\hline ELK LAKE (DES) & 4884 & 60 & 12.37 & 36.4 & 143.3 & 1237 & .013 & 19.54 & 92.9 & .0 & .2 & 7.0 & .0 & .0 & .63 & 12.0 & 62 & 7015 & .29 & 32.8 & .021 & 1.30 & 5.0 & .42 \\
\hline ELK LAKE (HIL) & 3760 & 85 & 1.50 & 90.0 & 167.1 & 450 & .018 & 15.00 & 87.1 & .0 & .0 & 7.2 & 5.7 & .0 & .10 & 12.0 & 30 & 800 & .11 & 30.0 & .003 & 1.60 & 5.0 & .42 \\
\hline EMIGRANT LAKE & 2174 & 30 & 62.63 & 13.3 & 219.4 & 10083 & .052 & 45.65 & 71.6 & 5.1 & 21.4 & 1.9 & .0 & .0 & 1.37 & 53.0 & 160 & 46500 & 1.05 & 7.9 & .016 & 1.00 & 54.0 & 1.02 \\
\hline FISH LAKE (ML) & 7371 & 15 & .38 & 12.5 & 49.0 & 38 & .086 & 15.20 & 86.6 & .0 & .0 & 11.4 & .0 & 0 & .03 & 15. & 30 & 200 & .7 & 17.4 & .022 & 5.8 & 18.0 & 1.20 \\
\hline FISH LAKE (PHR) & 6640 & 45 & .50 & 25.0 & -- & 750 & .040 & 4.76 & 62.5 & .0 & .0 & 16.7 & 20.8 & .0 & .11 & 13 & 49 & 900 & 1.35 & 16.4 & .007 & 3.00 & 5.0 & .38 \\
\hline FISH LAKE (RR) & 4642 & 52 & 19.65 & 30.1 & 210.0 & 1788 & .040 & 26.03 & 86.8 & .0 & .0 & 3.3 & 10.0 & .0 & .76 & 17.5 & 31 & 8440 & .27 & 19.7 & .029 & 1.90 & 14.0 & .80 \\
\hline FISH LAKE (UR) & 3405 & 47 & 7.25 & 35.0 & 421.1 & 2175 & .040 & 46.77 & 91.1 & .0 & 1.4 & 2.3 & 5.0 & .0 & .16 & 61.8 & 125 & 6093 & .45 & 25.3 & .005 & .30 & 25.0 & .40 \\
\hline FLORAS LAKE & 10 & 70 & 10.03 & 60.0 & 487.9 & 3009 & .040 & 27.18 & 90.0 & 4.0 & .0 & 5.0 & 1.0 & .0 & .37 & 18.0 & 35 & 4300 & .13 & 8.5 & .008 & .70 & 13.0 & .72 \\
\hline FOURMILE LAKE & 5744 & 35 & 8.81 & 35.0 & 150.0 & 951 & .040 & 7.39 & 82.8 & .0 & .0 & 10.4 & 6.8 & .0 & 1.19 & 55.0 & 175 & 41700 & 2.53 & 23.0 & .006 & .20 & 3.0 & .05 \\
\hline GLACIER LAKE & 8200 & 80 & .73 & 50.0 & --- & 799 & .040 & 10.00 & .0 & .0 & .0 & 9.4 & 90.6 & .0 & .07 & 52.0 & 125 & 2500 & .13 & 25.9 & .017 & .40 & 1.0 & .02 \\
\hline GOLD LAKE & 4813 & 62 & 18.85 & 29.5 & 527.0 & 1885 & .038 & 125.67 & 97.0 & .0 & .0 & 1.0 & 2.0 & .0 & .15 & 12.0 & 43 & 1100 & .04 & 14.8 & .047 & 1.90 & 16.0 & 1.33 \\
\hline HARNEY LAKE & 4084 & 25 & 5083.75 & 3.7 & -- & 259271 & -- & 123.24 & 23.3 & 6.8 & 67.2 & 2.3 & .0 & .4 & 41.25 & -- & -- & -- & -- & .7 & 1.140 & 5.20 & 1011.0 & -- \\
\hline HARRIETTE LAKE & 6750 & 35 & .54 & 15.0 & $\cdots$ & 54 & .040 & 8.57 & 98.0 & .0 & .0 & 2.0 & .0 & .0 & .06 & 35.0 & 79 & 1400 & 3.24 & 55.8 & .009 & .20 & 1.0 & .03 \\
\hline HEAVENLY THIN LA & 5975 & 55 & 2.27 & 38.4 & -- & 227 & .040 & 68.79 & 94.0 & .0 & .0 & 6.0 & .0 & .0 & .03 & 5.0 & 10 & 100 & .02 & 9.8 & .009 & .30 & 1.0 & .20 \\
\hline ISLAND LAKE & 5906 & 55 & -- & 35.0 & -- & -- & .040 & -- & 90.6 & .0 & .0 & 9.4 & .0 & .0 & .06 & 5.0 & 21 & 200 & -- & 21.0 & .009 & 3.00 & 7.0 & 1.40 \\
\hline JUBILEE LAKE & 4696 & 52 & 4.26 & 30.0 & -- & 426 & .040 & 30.21 & 96.4 & .0 & .0 & 3.4 & .0 & .0 & .14 & 16.0 & 45 & 1400 & .21 & 16.4 & .019 & 2.50 & -- & -- \\
\hline LAKE OF THE WOOD & 4949 & 37 & 24.21 & 25.4 & 300.0 & 3268 & .040 & 13.53 & 90.2 & .0 & .1 & 7.5 & 2.2 & .0 & 1.79 & 27.0 & 55 & 30500 & .93 & 23.1 & .017 & 3.60 & 8.3 & .31 \\
\hline LAVA LAKE & 4740 & 45 & 7.43 & 29.1 & -- & 743 & .013 & 12.92 & 92.7 & .0 & .2 & 6.4 & .7 & .0 & .58 & 20.0 & 34 & 7200 & .62 & 23.0 & .530 & 3.50 & 15.0 & .75 \\
\hline LINTON LAKE & 3502 & 82 & 14.92 & 50.0 & 467.1 & 1492 & .013 & 191.28 & 54.0 & .0 & .0 & 1.0 & 45.0 & .0 & .08 & 31.0 & 95 & 1500 & .04 & 45.3 & .032 & .20 & 2.0 & .06 \\
\hline LITTLE CULTUS LA & 4759 & 45 & 10.76 & 13.3 & 75.0 & 1076 & .013 & 44.10 & 94.6 & .0 & .5 & 4.2 & .7 & .0 & .24 & 17.0 & 55 & 2600 & .34 & 16.7 & .010 & 1.10 & 6.0 & .35 \\
\hline LITTLE LAVA LAKE & 4739 & 45 & 17.78 & 21.5 & -- & 1778 & .013 & 82.31 & 95.3 & .0 & .1 & 3.9 & .8 & .0 & .22 & 8.0 & 18 & 1100 & .20 & 18.0 & .088 & 1.90 & 18.0 & 2.25 \\
\hline LOST LAKE (HR) & 3143 & 110 & 2.14 & 85.0 & 239.8 & 214 & .013 & 5.93 & 84.4 & .0 & .0 & 15.6 & .0 & .0 & .36 & 77.0 & 175 & 17800 & 1.84 & 40.0 & .006 & .80 & 5.0 & .06 \\
\hline
\end{tabular}


DATA MatriX FOR SELECTEd OREGON LAKE-WATERSHEd ECOSYStemS

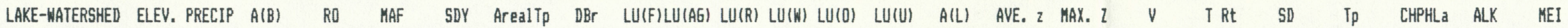

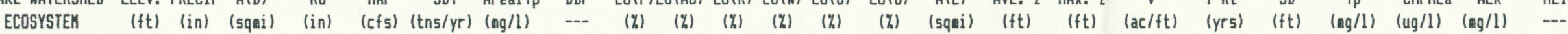

\begin{tabular}{|c|c|c|c|c|c|c|c|c|c|c|c|c|c|c|c|c|c|c|c|c|c|c|c|c|}
\hline LOST LAKE (HIL) & 3980 & 90 & 13.87 & 61.3 & 489.9 & 1387 & .026 & 104.29 & 99.0 & .0 & .0 & 1.0 & .0 & .0 & .13 & 4.0 & 9 & 300 & .01 & 6.6 & .019 & 1.30 & 20.0 & 5.00 \\
\hline LOMER EDDEELED L & 4820 & 70 & 2.74 & 35.0 & 44.3 & 247 & .026 & 16.81 & 91.0 & .0 & .0 & 9.0 & .0 & .0 & .16 & 70.0 & 123 & 7200 & 1.41 & 40.0 & .002 & .10 & 3.0 & .04 \\
\hline LOWER ERMA BELL & 4440 & 70 & 8.93 & 32.7 & 75.9 & 893 & .026 & 135.30 & 98.0 & .0 & .0 & 2.0 & .0 & .0 & .07 & 46.0 & 88 & 2000 & .13 & 22.0 & .007 & 1.10 & 10.0 & .22 \\
\hline LYTLE LAKE & 8 & 90 & 2.09 & 70.0 & 162.9 & 627 & .040 & 19.35 & 95.0 & .0 & .0 & 5.0 & .0 & .0 & .11 & 3.0 & 5 & 200 & .03 & 5.0 & -- & -- & 26.0 & 8.67 \\
\hline MAGONE LAKE & 5000 & 25 & 1.35 & 3.5 & 10.5 & 135 & .040 & 28.72 & 95.0 & .0 & .8 & 4.2 & .0 & .0 & .05 & 29.0 & 98 & 900 & 3.59 & 15.1 & .012 & 4.80 & 61.0 & 2.10 \\
\hline MANN LAKE & 4150 & 20 & 28.00 & 2.5 & 41.0 & 280 & .086 & 64.97 & .0 & 5.2 & 93.0 & .9 & .9 & .0 & .43 & 6.0 & 14 & 1600 & .43 & 2.0 & .218 & 2.60 & 313.0 & 52.17 \\
\hline MARION LAKE & 4130 & 90 & 13.59 & 69.6 & 450.3 & 1359 & .013 & 33.31 & 93.0 & .0 & $: 0$ & 5.0 & 2.0 & .0 & .41 & 64.0 & 185 & 16600 & .33 & 21.0 & .045 & .70 & 18.0 & .28 \\
\hline MERCER LAKE & 32 & 83 & 8.44 & 50.0 & 317.5 & 2532 & .040 & 15.04 & 90.6 & .0 & 3.0 & 5.9 & .0 & .5 & .56 & 23.0 & 38 & 8300 & .37 & 7.2 & .026 & 8.50 & 7.3 & .32 \\
\hline HIDDLE GREEN LAK & 6505 & 80 & 2.57 & 50.0 & 50.5 & 257 & .013 & 19.92 & 10.7 & .0 & .0 & 6.0 & 83.2 & .0 & .13 & 18.0 & 55 & 1500 & .22 & 23.6 & .017 & .20 & 4.0 & .22 \\
\hline HILLER LAKE & 5630 & 39 & 10.12 & 35.8 & 73.3 & 1012 & .040 & 11.45 & 90.6 & .0 & 1.2 & 7.7 & .5 & .0 & .88 & 77.3 & 145 & 43723 & 2.27 & 29.2 & .023 & 1.90 & 7.0 & .09 \\
\hline MINAM LAKE & 7370 & 75 & .72 & 60.0 & $\cdots$ & 1080 & .040 & 8.67 & 5.9 & .0 & .0 & 9.6 & 84.5 & .0 & .08 & 10.0 & 28 & 500 & .22 & 26.2 & .013 & .30 & 2.0 & .20 \\
\hline MIRROR LAKE & 7650 & 75 & .76 & 60.0 & -- & 1140 & .040 & 18.54 & 45.0 & .0 & .0 & 5.0 & 50.0 & .0 & .04 & 29.4 & 75 & 775 & .32 & 41.7 & .018 & .10 & 2.0 & .07 \\
\hline MONON LAKE & 4959 & 110 & 1.15 & 58.0 & 40.9 & 115 & .013 & 7.52 & 87.6 & .0 & .0 & 12.4 & .0 & .0 & .15 & 7.0 & 39 & 700 & .20 & 39.0 & .007 & .20 & 1.0 & .14 \\
\hline MORGAN LAKE & 4154 & 22 & 4.51 & 3.5 & 18.1 & 451 & .086 & 47.98 & 65.5 & .0 & 32.5 & 2.0 & .0 & .0 & .09 & 16.0 & 26 & 1000 & 1.19 & 7.9 & .056 & 1.80 & 28.0 & 1.75 \\
\hline MONICH LAKE & 5077 & 85 & 2.32 & 70.0 & 87.5 & 232 & .021 & 30.13 & 97.0 & .0 & .0 & 3.0 & .0 & .0 & .08 & 19.0 & 52 & 900 & .10 & 51.8 & .005 & .10 & 1.0 & .05 \\
\hline MUNSEL LAKE & 90 & 75 & 1.63 & 50.0 & 54.3 & 489 & .040 & 9.48 & 57.3 & .0 & .0 & 24.9 & 17.8 & .0 & .17 & 31.0 & 71 & 3400 & .78 & 14.7 & .012 & 1.60 & 6.5 & .21 \\
\hline NORTH TENMILE LA & 9 & 86 & 27.28 & 55.4 & 1082.6 & 8184 & .035 & 15.90 & 93.0 & .0 & .0 & 5.0 & .0 & 2.0 & 1.72 & 11.0 & 23 & 12100 & .15 & 5.6 & .016 & 5.70 & 10.0 & .91 \\
\hline NORTH THIN LAKE & 4339 & 22 & .51 & 7.0 & $\cdots$ & 51 & .040 & 2.91 & 66.0 & .0 & .0 & 34.0 & .0 & .0 & .18 & 40.0 & 63 & 4500 & 23.77 & 31.5 & .010 & 1.80 & 73.0 & 1.83 \\
\hline ODELL LAKE & 4787 & 59 & 31.40 & 35.0 & 406.3 & 3140 & .040 & 5.61 & 81.0 & .0 & .0 & 15.0 & 4.0 & .0 & 5.60 & 132.0 & 282 & 473900 & 8.08 & 23.0 & .095 & 5.40 & 13.0 & .10 \\
\hline OLALLIE LAKE & 4936 & 110 & 3.11 & 61.6 & 98.0 & 311 & .013 & 10.58 & 88.8 & .0 & .0 & 10.5 & .7 & .0 & .29 & 17.0 & 43 & 3100 & .30 & 41.5 & .005 & .20 & 1.0 & .06 \\
\hline OLIVE LAKE & 6012 & 35 & 3.97 & 15.0 & 105.0 & 397 & .040 & 16.61 & 93.0 & .0 & .0 & 7.0 & .0 & .0 & .24 & 25.0 & 90 & 3900 & 1.23 & 23.9 & .008 & 4.30 & 13.0 & .52 \\
\hline OSWEGO LAKE & 99 & 40 & 6.38 & 17.4 & 119.9 & 1914 & .072 & 9.92 & 12.6 & 5.6 & .0 & 9.7 & .0 & 72.1 & .64 & 25. & 55 & 10605 & 1.79 & 5.6 & .127 & 2.30 & 49.0 & 1.88 \\
\hline PAMELIA LAKE & 3884 & 95 & 6.93 & 107.4 & 424.1 & 693 & .013 & 92.40 & 84.0 & .0 & .0 & 1.0 & 15.0 & .0 & .08 & 3.0 & 15 & 200 & .01 & -- & .032 & --- & 3.0 & 1.00 \\
\hline PAULINA LAKE & 6331 & 35 & 5.61 & 10.0 & -- & 561 & .040 & 2.35 & 55.5 & .0 & .0 & 25.7 & 18.9 & .0 & 2.39 & 163.0 & 250 & 249800 & 83.82 & 25.3 & .033 & 13.00 & 336.0 & 2.06 \\
\hline COTT LAKE & 4810 & 94 & 1.66 & 60.0 & 52.9 & 166 & .013 & 40.49 & 98.0 & .0 & .0 & 2.0 & .0 & .0 & .04 & 4.0 & 19 & 100 & .0 & 19.0 & .010 & .20 & 1.0 & .25 \\
\hline SILTCOOS LAKE & 8 & 85 & 63.06 & 63.5 & 2596.5 & 11603 & .024 & 12.75 & 87.9 & 1.1 & 1.3 & 8.7 & .5 & .5 & 4.94 & 11. & 22 & 33900 & .16 & 6.1 & .039 & 4.90 & 8.0 & .73 \\
\hline SOUTH TWIN LAKE & 4333 & 22 & .30 & 7.0 & --- & 30 & .040 & 1.94 & 44.0 & .0 & .0 & 56.0 & .0 & .0 & .16 & 33 & 58 & 3300 & 29.63 & 27.9 & .017 & 1.00 & 56.0 & 1.70 \\
\hline SPARKS LAKE & 5428 & 65 & 35.78 & 40.5 & 651.6 & 3578 & .017 & 29.40 & 68.3 & .0 & 1.3 & 3.2 & 27.2 & .0 & 1.22 & 1.0 & 7 & 1000 & .01 & 7.0 & .022 & .30 & 5.0 & 5.00 \\
\hline SQUAH LAKE & 3004 & 41 & 18.93 & 17.0 & 608.7 & 1193 & .040 & 262.92 & 98.0 & .0 & 1.0 & 1.0 & .0 & .0 & .07 & 53.9 & 121 & 2456 & .1 & 20.3 & .009 & 2.80 & 103.0 & 1.91 \\
\hline STRANBERRY LAKE & 6380 & 45 & 3.44 & 12.1 & 90.0 & 344 & .040 & 61.43 & 76.8 & .0 & 18.4 & 1.5 & 3.3 & .0 & .06 & 9. & 27 & 300 & .14 & 21.7 & .051 & .30 & 14.0 & 1.56 \\
\hline SUMMER LAKE & 4146 & 18 & 336.94 & 1.8 & -- & 33694 & .081 & 8.63 & 7.0 & 5.0 & 50.0 & 13.0 & 25.0 & .0 & 39.06 & 1.0 & 2 & 25000 & 3.50 & .3 & 6.400 & 53.10 & 2649.0 & 2649.00 \\
\hline SUMMIT LAKE & 5553 & 60 & 7.25 & 35.0 & -- & 725 & .040 & 9.63 & 84.4 & .0 & .0 & 13.1 & 2.5 & .0 & .75 & 23.0 & 63 & 11000 & .81 & 39.4 & .009 & .10 & 1.0 & .04 \\
\hline SUNSET LAKE & 21 & 80 & -- & 60.0 & $\cdots$ & -- & .040 & $\cdots$ & 11.0 & .0 & 54.0 & 17.0 & 4.0 & 14.0 & .1 & 8. & 19 & 900 & -- & 3.0 & .080 & 8.30 & 48.0 & 6.00 \\
\hline SUTTLE LAKE & 3438 & 67 & 20.61 & 48.4 & 475.2 & 2061 & .013 & 52.18 & 93.0 & .0 & 1.0 & 2.7 & 3.3 & .0 & .4 & 44. & 75 & 11200 & .24 & 11.6 & .043 & 14.00 & 20.0 & .45 \\
\hline SUTTON LAKE & 29 & 78 & 10.83 & 50.0 & 402.5 & 3249 & .040 & 64.85 & 89.7 & .0 & 3.1 & 6.5 & .0 & .7 & .17 & 19 & 33 & 2000 & .07 & 6.2 & .027 & 12.00 & 10.0 & .53 \\
\hline TAHKENITCH LAKE & 11 & 83 & 31.38 & 52.6 & 1390.1 & 19926 & .031 & 12.00 & 88.3 & .0 & 2.0 & 7.3 & 2.3 & .1 & 2.62 & 10 & 23 & 18199 & .21 & 7.9 & .018 & 4.80 & 10.3 & .94 \\
\hline TENHILE LAKE & 9 & 83 & 67.46 & 61.1 & 2824.8 & 20247 & .031 & 26.54 & 93.0 & .0 & .0 & 5.0 & .0 & 2.0 & 2.54 & 10.0 & 22 & 16200 & .07 & 9.0 & .013 & 4.70 & 14.5 & 1.45 \\
\hline THREE CREEK LAKE & 6550 & 37 & .88 & 35.0 & 21.7 & 88 & .026 & 7.39 & 64.2 & .0 & .0 & 11.2 & 24.6 & .0 & .12 & 11.0 & 30 & 800 & .49 & 30.0 & .011 & .70 & 2.0 & .18 \\
\hline THREEMILE LAKE & 20 & 75 & 1.60 & 60.0 & 79.5 & 480 & .040 & 16.33 & 90.0 & .0 & .0 & 10.0 & .0 & .0 & .10 & 13 & 33 & 800 & .16 & 13.1 & -- & -- & 11.0 & .85 \\
\hline TODD LAKE & 6151 & 50 & .86 & 35.0 & 17.1 & 86 & .026 & 19.11 & 85.0 & .0 & 10.3 & 4.7 & .0 & .0 & .0 & 21. & 60 & 600 & .3 & 22.7 & .063 & .90 & 11.0 & .52 \\
\hline TORREY LAKE & 5280 & 74 & 4.00 & 23.4 & -- & 400 & .026 & 38.83 & 90.0 & .0 & .0 & 10.0 & .0 & .0 & .1 & 5. & 13 & 400 & .0 & 12.8 & .007 & .40 & 2.0 & .40 \\
\hline TRIANGLE LAKE & 695 & 90 & 53.56 & 53.8 & 3425.6 & 12212 & .018 & 122.84 & 92.6 & 3.0 & 3.5 & .9 & .0 & .5 & .4 & 52.0 & 95 & 14500 & .09 & 11.5 & .012 & 2.10 & 6.0 & .12 \\
\hline TRILLIUM LAKE & 3601 & 80 & .81 & 65.0 & 25.3 & 243 & .013 & 9.10 & 84.0 & .0 & 5.0 & 11.0 & .0 & .0 & .09 & 6.0 & 16 & 300 & .11 & 11.5 & .011 & 3.00 & 12.0 & 2.00 \\
\hline UPPER COH LAKE & 4338 & 12 & 208.52 & 1.7 & -- & 16265 & .086 & 141.18 & .0 & .0 & 94.0 & 1.0 & 5.0 & .0 & 1.48 & 7.1 & 16 & 6700 & .36 & .7 & .204 & 5.60 & 55.0 & 7.75 \\
\hline UPPER KLAMATH LA & 4139 & 38 & 3713.83 & 10.4 & 11600.0 & 2339713 & .050 & 38.62 & 72.9 & 7.6 & 13.3 & 3.5 & 2.5 & .0 & 96.16 & 13.8 & 50 & 849290 & .41 & 5.0 & .141 & 4.20 & 44.0 & 3.19 \\
\hline VALSETZ LAKE & 1099 & 130 & 17.41 & 90.0 & 1666.8 & 5223 & .018 & 29.56 & 95.6 & .0 & .0 & 3.1 & .0 & 1.2 & .59 & 12.0 & 35 & 4400 & .05 & 8.2 & .029 & 1.60 & 15.0 & 1.25 \\
\hline WAHTUM LAKE & 3732 & 85 & .60 & 70.0 & 59.1 & 60 & .013 & 6.19 & 86.1 & .0 & .0 & 13.9 & .0 & .0 & .10 & 60.0 & 184 & 3700 & 1.79 & 35.1 & .004 & .70 & 3.0 & .05 \\
\hline WALDO LAKE & 5414 & 72 & 21.16 & 26.3 & 186.4 & 2116 & .028 & 2.15 & 69.2 & .0 & .0 & 30.8 & .0 & .0 & 9.84 & & 420 & 787400 & 21.20 & 59.0 & .005 & .10 & .1 & .00 \\
\hline HALLOHA LAKE & 4383 & 48 & 48.65 & 36.7 & -- & 72975 & .040 & 20.65 & 11.7 & .0 & 2.6 & 5.9 & 79.0 & .0 & 2.36 & 161.0 & 299 & 243500 & 2.56 & 20.5 & .023 & 1.30 & 31.5 & .20 \\
\hline WALTON LAKE & 5200 & 25 & .87 & 10.0 & -- & 87 & .040 & 31.07 & 92.0 & .0 & .0 & 8.0 & .0 & .0 & .03 & 12.0 & 21 & 200 & .43 & 8.9 & .039 & 3.20 & 55.0 & 4.58 \\
\hline MOAHINK LAKE & 38 & 78 & 5.72 & 50.0 & 187.8 & 1716 & .040 & 4.47 & 80.9 & .0 & .0 & 16.6 & .0 & 2.5 & 1.28 & 33.0 & 68 & 26700 & 1.75 & 16.9 & .006 & 1.90 & 4.8 & .15 \\
\hline
\end{tabular}


APPENDIX B

MAPS OF AVERAGE ANNUAL PRECIPITATION, RUNOFF, AND STREAM TOTAL-PHOSPHORUS CONCENTRATIONS

The following maps were used as sources for the data variables Precipitation (PRECIP), Runoff (RO), Areal Total-Phosphorus (A-Tp), Theoretical Retention Time (TRt), and Mean Annual Flood (MAF). 
Normal Annual Precipitation

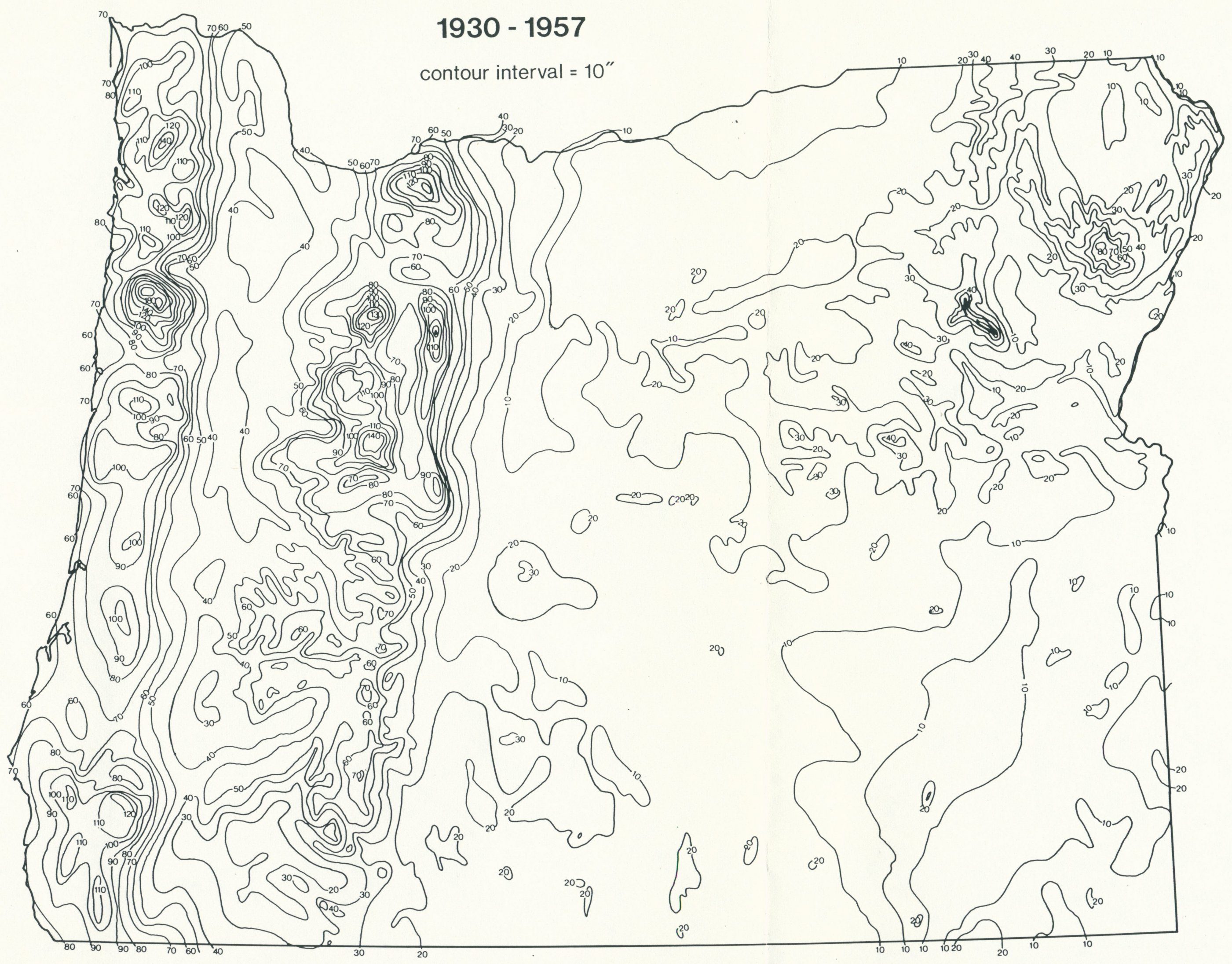

Source: Soil Conservation Service, 1964 


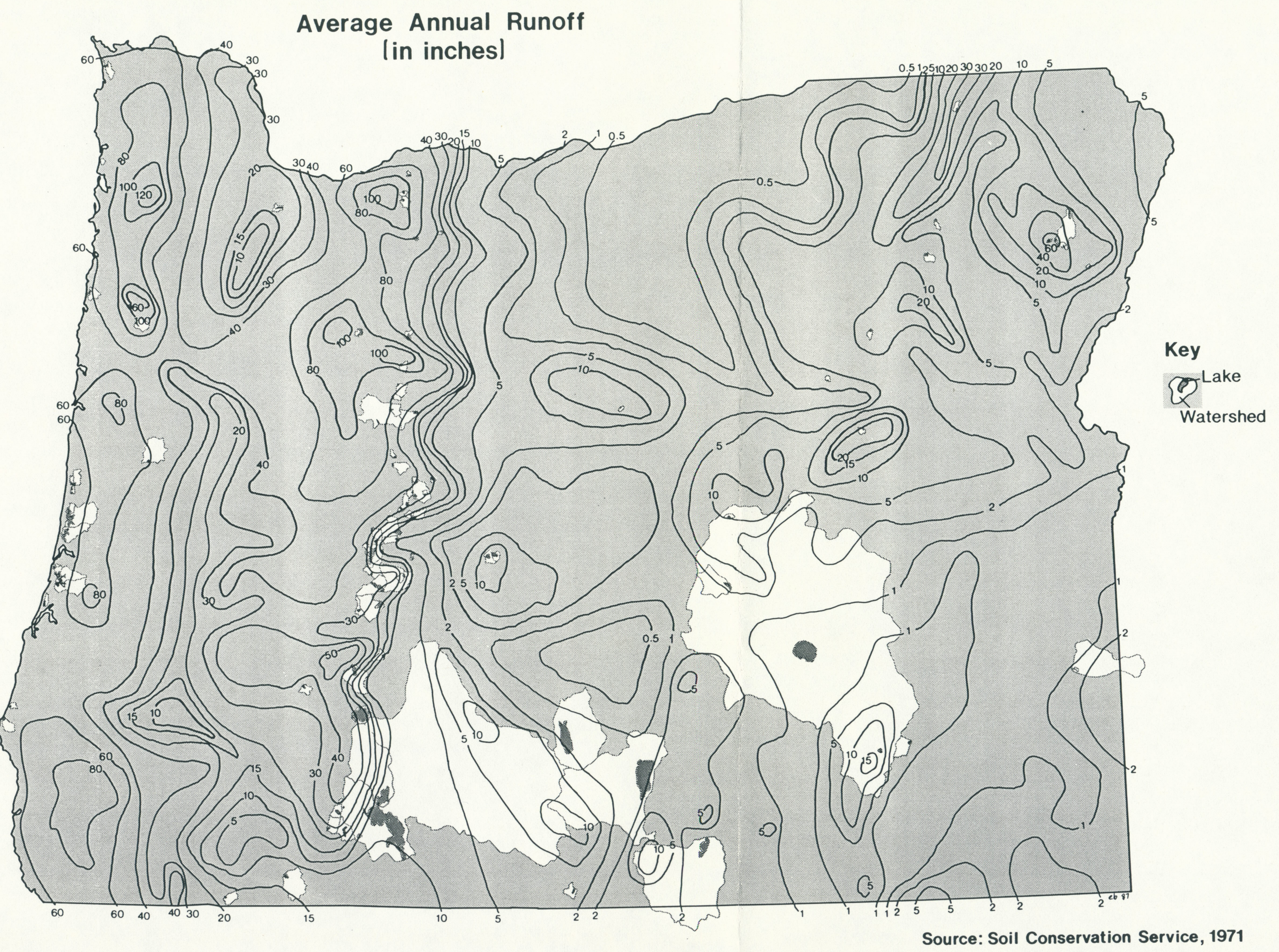




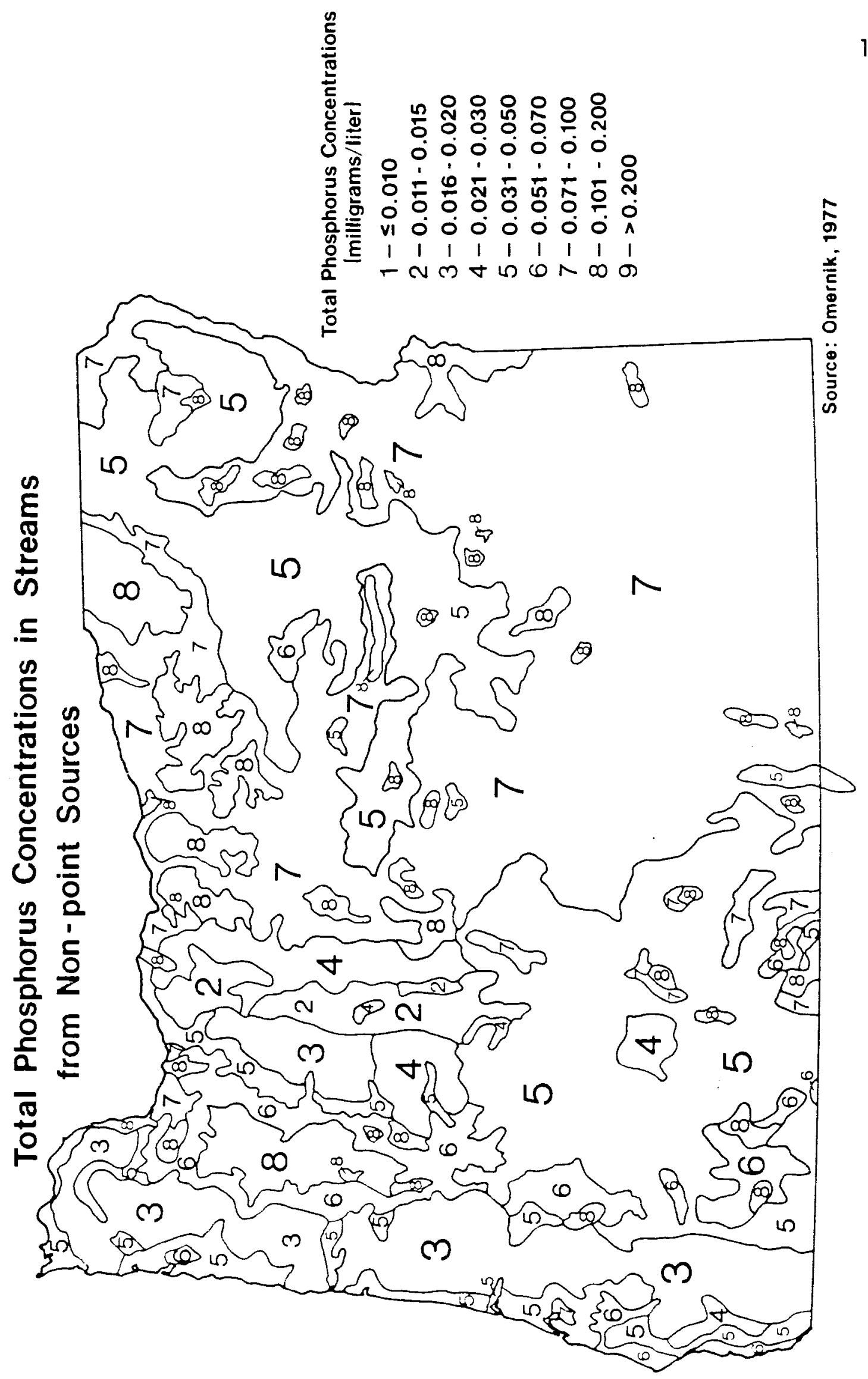


APPENDIX C

THE GENERATION AND RELATIVE ACCURACY OF THE AVERAGE ANNUAL RUNOFF VARIABLE USED IN THE ANALYSIS OF SELECTED LAKE-WATERSHED ECOSYSTEMS OF OREGON

The U.S. Soil Conservation Service map of average annual runoff (Appendix B) was used to develop runoff data values for the 98 lake-watershed ecosystems selected for inclusion in this thesis. This. was the only reasonable source for generating runoff values for ungaged watersheds. A weighted areal average was used in deriving the values. The method used is also the same used for generating values for A-Tp, and PRECIP.

1. Delineate watershed boundaries on runoff map.

2. Digitize areas between runoff isopleths that cross the watershed and record in percent-watershed-area (for those watersheds not crossed by one or more isopleths, a single runoff value was assigned on the basis of its proximity to the nearest isopleths).

3. Multiply the digitized areas between isopleths by the mean of the two bounding runoff values. Sum all weighted areas to equal a Total Average Annual Watershed Runoff vaiue (equivalent depth in inches) and convert to runoff in feet per year.

4. Convert watershed area to acres and multiply by Total Average Annual Runoff in feet $=$ Average Annual Runoff in acre-feet per year. The units were then converted to inches per year, as reported in the data matrix (Appendix A).

The U.S. Geological Survey Surface Water Records (1979) were consulted to check the accuracy of derived runoff values. Only nine of 
the selected lake-watershed ecosystems have gaging stations at their outlets or immediately downstream. Because the runoff values generated represent surface runoff to the lakes, they were adjusted, for comparison purposes with the USGS data, using net-precipitation over the lakes. There seemed to be a significant discrepancy between the actual USGS figures and the estimated values. A scatterplot and least-squares linear regression shows this discrepancy (Figure 16). Both long-term averages and, in general, there was an overestimation of gaged runoff by the estimated values.

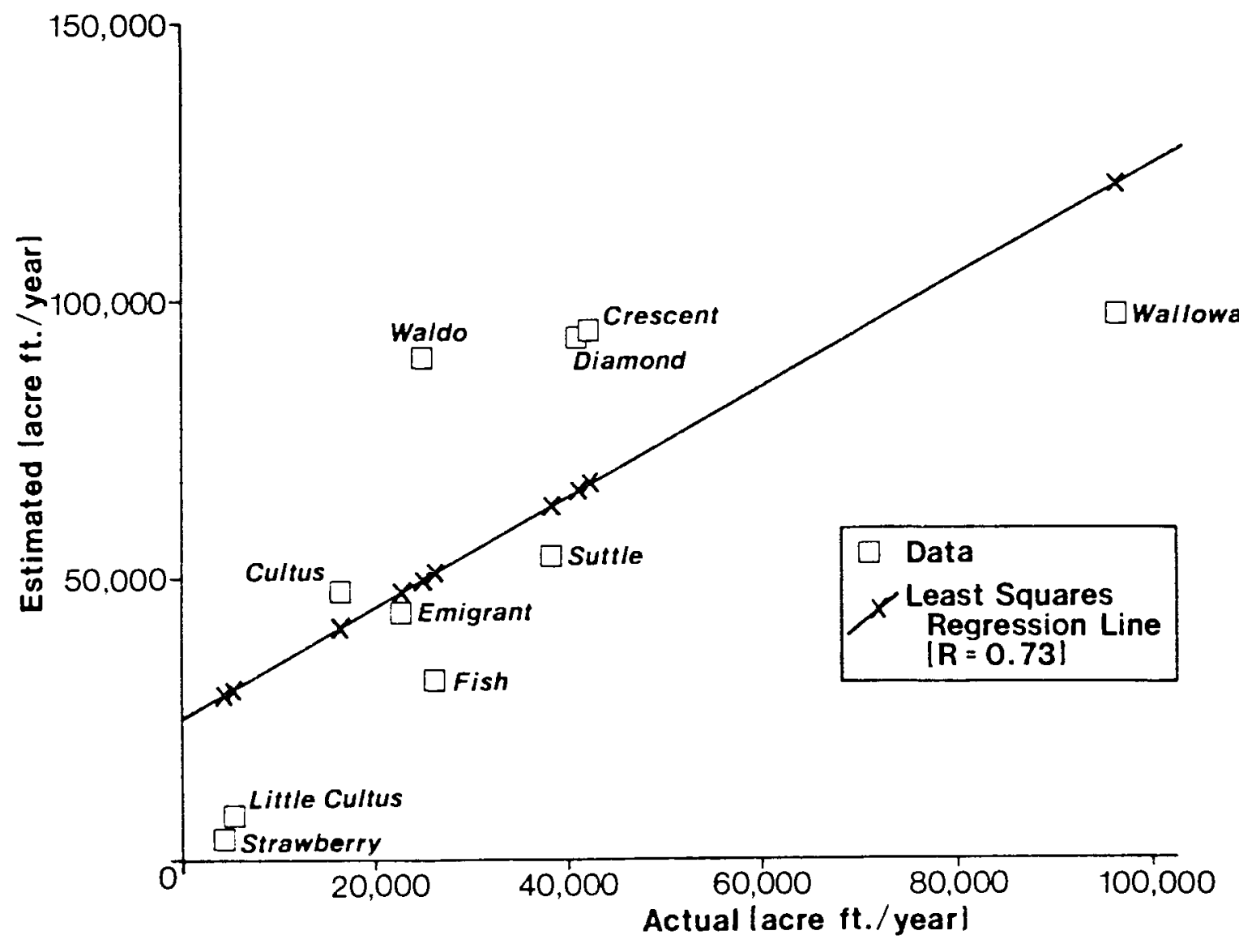

Figure 16. Actual USGS runoff data vs. estimated runoff data.

The differences between the two measures are assumed, herein, to be a function of 1) inaccuracies in the SCS runoff map; 2) inaccuracies in 
the delination of watershed boundaries; or 3) the loss of surface runoff to subsurface flow which would then not be reflected in surface water gaging records. Time limitations prevented more extensive research into the underlying causes of the discrepancies noted, nor did the purpose of the thesis require "absolute" accuracies in runoff data. The runoff data collected and reported are accurate, however, relative to each selected lake-watershed ecosystem. 


\section{APPENDIX D}

A METHOD FOR THE CALCULATION OF THEORETICAL RETENTION TIME

The formula used for the calculation of the Theoretical Retention Time (TRt) data variable is given as follows:

$$
\text { TRt years }=\frac{V}{\text { ASO }}
$$

where

$$
\begin{aligned}
V= & \text { Lake volume in acre-feet } \\
\text { ASO = } & \text { Annual surface outflow from the lake } \\
& \text { in acre-feet per year }
\end{aligned}
$$

Annual surface outflow is assumed to be equivalent to average annual runoff to the lakes, as the runoff values represent long-term averages -- periods longer than almost all retention times. Volume data were taken from Johnson et al. (1985). It may be useful for some purposes to note that the reciprocal of TRt is "Lake Flushing Rate" in years: the number of times a lake has its volume replaced in a normal year. 